WAGNER ROBY GÍDARO

\title{
AS MEDIDAS ESPECIAIS DE PROTEÇÃO A VÍTIMAS, TESTEMUNHAS E RÉUS COLABORADORES COMO MECANISMO DE EFETIVIDADE DO PROCESSO PENAL
}

Dissertação apresentada à Comissão Julgadora da Faculdade de Direito da Universidade de São Paulo, como exigência parcial para obtenção do título de Mestre em Direito Processual, área de concentração, Direito Processual Penal, sob a orientação do Professor Doutor José Raul Gavião de Almeida. 


\section{AS MEDIDAS ESPECIAIS DE PROTEÇÃO A VÍTIMAS, TESTEMUNHAS E RÉUS COLABORADDORES COMO MECANISMO DE EFETIVIDADE DO PROCESSO PENAL}

Banca Examinadora

Orientador:

Prof. Dr. José Raul Gavião de Almeida

$1^{\mathrm{o}}$ membro:

$2^{\mathrm{o}}$ membro: 
À memória de meu pai, responsável direto pela minha formação e por ter me ensinado tantas coisas, até mesmo sem saber disso.

Às inúmeras pessoas que se dedicam ao árduo e perigoso desenvolvimento do programa de proteção de vítimas e testemunhas no Brasil, sejam os voluntários da rede de assistência que garantem o sigilo da proteção e o trabalho, sejam os técnicos especialmente contratados para a execução do programa e bem-estar dos protegidos. 


\section{AGRADECIMENTOS}

Este trabalho é fruto de pesquisa incentivada pelo Prof. José Raul Gavião de Almeida, a quem agradeço a confiança, o apoio e, em especial, a oportunidade. Muito me honra ser seu aluno.

Agradeço ao Desembargador Eduardo Pereira Santos, Presidente da Seção Criminal do Tribunal de Justiça do Estado de São Paulo, pela confiança depositada ao me indicar como membro do Conselho Deliberativo do Programa de Proteção de Vítimas e Testemunhas do Estado de São Paulo como representante do Poder Judiciário Estadual, o que contribuiu em muito para o desenvolvimento deste trabalho.

Expresso também meus agradecimentos ao amigo João Rodrigues da Costa Bonvicino, que contribuiu com fundamental pesquisa de doutrina.

Agradeço, ainda, a meus amigos Sidney Ferreira da Silva e Bruno Debernardi, pela tradução do Resumo. 
"De tanto ver triunfar as nulidades; de tanto ver prosperar a desonra, de tanto ver crescer a injustiça, de tanto ver agigantarem-se os poderes nas mãos dos maus, o homem chega a desanimar da virtude, a rir-se da honra e a ter vergonha de ser honesto."

RUI BARBOSA 


\section{RESUMO}

GÍDARO, Wagner Roby. As medidas especiais de proteção a vítimas, testemunhas e réus colaboradores como mecanismo de efetividade do processo penal. 2010. 155 f. Dissertação (Mestrado em Direito Processual) - Faculdade de Direito da Universidade de São Paulo, São Paulo, 2010.

Este trabalho objetiva o estudo da efetividade do processo, embora não avance na análise de todos os mecanismos processuais, limitando-se ao instituto específico da proteção de vítimas, testemunhas e réus colaboradores estabelecido pela Lei $n^{0}$ 9.807/99. É cediço que a prova consiste em meio pelo qual o espírito humano se apodera da verdade, sendo eficaz quando o induz nessa crença. O resultado deve atribuir certeza, que é crença na percepção da conformidade da noção ideológica com a realidade. A prova testemunhal, por sua vez, continua sendo necessária para investigação e persecução do crime, ainda que avanços tecnológicos possam ter estabelecido outras fontes e meios de provas atípicos. Todavia, a violência e a agressividade do crime organizado, aliadas a outros fatores como a divulgação terrificante da mídia, acarretam inevitável prejuízo à prova testemunhal na medida em que testemunhas e vítimas não se sentem seguras para colaborar com a investigação policial ou a instrução judicial. Houve, assim, a necessidade de estabelecer a proteção de testemunhas e vítimas, como instituto processual, a fim de garantir a tranquilidade para a realização de seus depoimentos. Esse instituto é, pois, mais um mecanismo processual de efetividade do processo penal, medida alentada hodiernamente por aplicadores e estudiosos do direito processual. A efetividade do processo consiste nas soluções para frustrante ineficácia prática da tutela jurisdicional. Processo efetivo é aquele que alcança o equilíbrio entre os valores segurança e celeridade trazendo ao mundo das partes o resultado material desejado com pacificação social. A eliminação do conflito sem um critério necessário de justiça equivale ao incentivo das decepções coletivas atualmente corriqueiras, mantendo o estado anímico de insatisfação que foi o móvel da busca pela tutela jurisdicional. Não se pode pensar tudo isso e, ao mesmo tempo, olvidar-se das garantias constitucionais previstas ao réu no processo penal. São as limitações do poder estatal em detrimento dos direitos assegurados para a liberdade individual. É pertinente ressaltar, então, o princípio da proporcionalidade, pelo qual deverá o operador do direito sopesar os valores colocados em conflito, a fim de estabelecer a possibilidade plena da produção da prova, sem, no entanto, atingir os direitos fundamentais previstos ao réu no processo penal.

PALAVRAS-CHAVE: Efetividade do processo penal. Prova testemunhal. Proteção de testemunhas. Crime organizado. Garantias. Proporcionalidade. 


\begin{abstract}
GÍDARO, Wagner Roby. Special measures of protection of victims, witnesses and collaborative defendants as a mechanism for effectiveness of the penal process. 2010. $155 \mathrm{f}$. Essay (Masters in Procedural Process) - Faculdade de Direito da Universidade de São Paulo, São Paulo, 2010.

This paper aims the effectiveness of the process, although it does not improve on the study of all process mechanisms, restricting itself to the specific established law of protection of victims, witnesses and collaborative defendants Law n. ${ }^{\circ} 9,807 / 99$. The evidence is the mean by which the human spirit takes possession of the truth. The result must attribute certainty, which is the belief in the perception of conformity between the ideological notion and reality. The testimony evidence, by its turn, remains being necessary to the investigation and prosecution of the crime, even though technological improvements may have established other sources and means of atypical evidences. However, the violence and aggressiveness of the criminal organizations, plus other factors as media terrifying divulgation, bring unavoidable damages to the testimony evidence as witnesses and victims do not feel safe enough to cooperate with the police investigation or legal proceeding in court. It was necessary to set up on the protection of witnesses and victims, as process established law, to warrant the reassurance for their testimony. That established law is, then, one more process mechanism of effectiveness of penal process, a measure encouraged nowadays by process law applicants and studious. The effectiveness of the process consists in solutions for the frustrating practical inefficacy of the jurisdictional tutelage. Effective process is the one which achieves the balance between security and celerity values, bringing to the world of the parties the material result wished together with social pacification. The elimination of the conflict without a necessary justice criterion is equivalent to encourage the collective deceptions currently usual, sustaining the spirit of dissatisfaction that was the motive for the jurisdictional tutelage quest. Obviously, one cannot think on everything said, and, at the same time, forget the constitutional warrants foreseen to the defendant in the penal process. Those are limitations of the state power to the detriment of the individual freedom established rights. It pays to remind, then, the proportionality principle, thru which the law operator must ponder the values set in conflict, to establish the complete possibility to produce the evidence, without, yet, coming against the fundamental rights provided to the defendant in the penal process.
\end{abstract}

KEYWORDS: Effectiveness of the process. Testimony evidence. Protection of witnesses. Organized crime. Constitutional warrants. Proportionality. 


\section{RIASSUNTO}

GÍDARO, Wagner Roby. Le misure speciale di protezione alle vittime, testimoni e colaboratori della giustizia come strumento della effetività dei processo penale. 2010. 155 f. Dissertazione (Maestrato di Diritto Processuale) - Faculdade de Direito da Universidade de São Paulo, São Paulo, 2010.

Questa tesi intenta il studio della effetività dei processo, peraltro no avanze nella ricerca di tutti i strumenti processuali, limitando al stituto specifico della protezione di vittime, testimoni e colaboratori della giustizia allevato sulla Lege $n .^{\circ}$ 9.807/99. È saputo che la prova consiste in mezzo per il spirito umano prende la verità, essendo efficace ove indurre questa convinzione. La conclusione debbe conferire certezza, che è la convinzione nella percezione secondo la nozione ideologica con la realità. La prova testemoniale, comunque, continua essendo necessaria per l'indagine e persecuzione del reato, ancora che avanzamenti tecnologici stabiliscono altre fonti e mezzi di prove atipici. Peraltro, la violenza e l'agressività dei crimine organizato, alleate a altri fattori come la divulgazione terrificante della midia, motivano inevitabile danno alla prova testimoniale dunque le testimone e vittime sono sicure affinché collaborare con l'accertamento della polizia oppure la prova judiziale. Ho avuto, dunque, la necessità di stabilire la protezione di testemoni e vittime, come stituto processuale, affinché assicurare la tranquilità per compire la testimonianza. Questo stituto é, dunque, più che altro un strumento processuale di effetività dei processo penale, misure cercata al presente per dottrinatori dei diritto processuale. L'effetività dei processo consiste nei soluzioni per la scontenta ineficace pratica della tutela giurisdizionale. Processo effetivo é quale che raggiundere l'equilibrio fra i valori sicurezza e velocità che trarre ao mondo dei parti la risultato materiale cercato con la pacificazione sociale. La eliminazione dei conflito senza criterio di giustizia risulta in incentivo delle disilluzioni colletivi al presente comuni, ritenendo il stato animico di malcontento che ha determinato la cerca della tutela giurisdizionale. Peraltro, non si può pensare questo e, ancora, dimenticarsi dei assicuramenti costituzionali previsti all'imputato nel processo penale. Sono limitazione del potere statale in detrimento dei diritti assecurati per la libertà particolare. È pertinente mettere in evidenza, dunque, il principio della proporcionalità, ove il operatore del diritto misura i valori del conflito, affinché stabilire la possibilità piena della produzione della prova, senza attingere i diritti fundamentali previsti all'imputato nel processo penale.

PAROLE CHIAVE: Effetività del processo penale. Prova testemoniale. Protezione di testemoni. Crimine organizato. Assicuramenti. Proporcionalità. 


\section{SUMÁRIO}

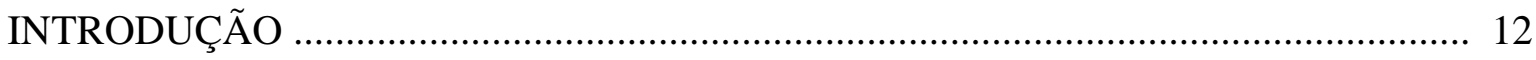

1. NOÇÕES PRELIMINARES SOBRE A PROVA ................................................. 21

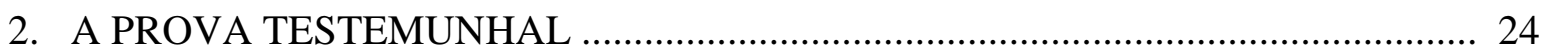

3. PRESENÇA FÍSICA DO RÉU EM AUDIÊNCIA................................................ 31

4. AS INOVAÇÕES DA LEI No 11.690/08 ........................................................... 37

5. HISTÓRICO DA CRIMINALIDADE E DA AGRESSIVIDADE CONTRA

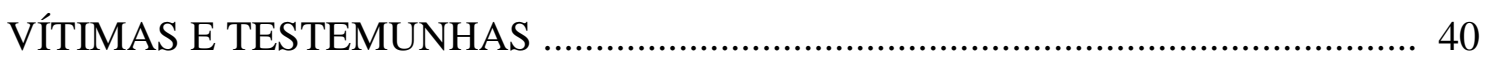

6. MECANISMOS DE COMBATE AO CRIME ORGANIZADO …...........................49

7. O EQUILÍBRIO ENTRE A EFICIÊNCIA E O GARANTISMO .............................. 53

8. MEDIDAS ESPECIAIS DE PROTEÇÃO .......................................................... 59

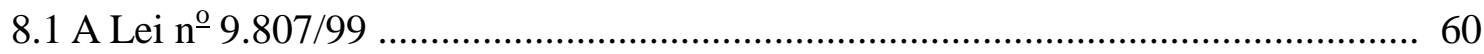

8.1.1 Legitimidade para o requerimento .................................................... 61

8.1.2 Critérios e requisitos para inclusão ...................................................... 62

8.1.2.1 Ser vítima ou testemunha de crime que possam colaborar em investigação ou processo criminal ...................................................... 63

8.1.2.2 Ter sido coagida ou exposta a grave ameaça ............................... 65

8.1.2.3 Não ter personalidade ou conduta incompatível com as restrições de comportamento exigidas no programa ............................................. 65

8.1.2.4 Não ser condenado cumprindo pena e não estar sob prisão cautelar, seja qual for a modalidade ................................................... 68

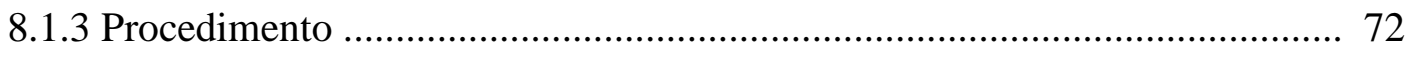

8.1.4 Formação do programa ....................................................................... 74

8.1.5 Exclusão do programa …...................................................................... 77

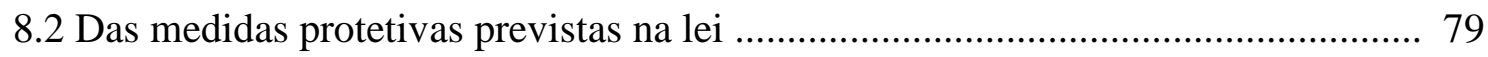

8.2.1 Segurança na residência, incluindo o controle de telecomunicações ........... 79

8.2.2 Escolta e segurança nos deslocamentos da residência, inclusive para

fins de trabalho ou para prestação de depoimentos ............................................ 80

8.2.3 Transferência de residência ou acomodação provisória em local 
compatível com a proteção

8.2.4 Preservação da identidade, imagem e dados pessoais

8.2.5 Ajuda financeira mensal para prover as despesas necessárias à subsistência individual ou familiar, no caso de a pessoa protegida estar impossibilitada de desenvolver trabalho regular ou de inexistência de qualquer fonte de custeio

8.2.6 Suspensão temporária das atividades funcionais, sem prejuízo dos

Respectivos vencimentos ou vantagens, quando servidor público 88

8.2.7 Apoio e assistência social, médica e psicológica 88

8.2.8 Sigilo em relação aos atos praticados em virtude da proteção concedida .... 88

8.2.9 Apoio do órgão executor do programa para o cumprimento de obrigações civis e administrativas que exijam o comparecimento pessoal ............................ 89

8.2.10 Alteração do nome do protegido ........................................................... 89

8.3 Programas de proteção no direito estrangeiro ......................................................... 96

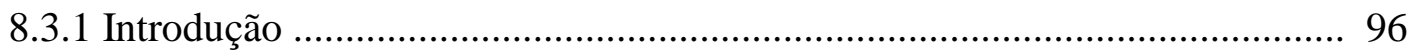

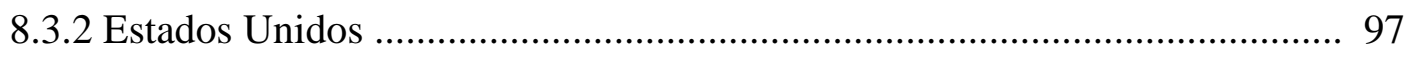

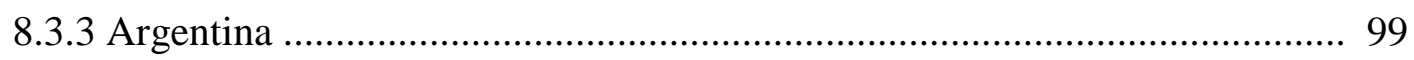

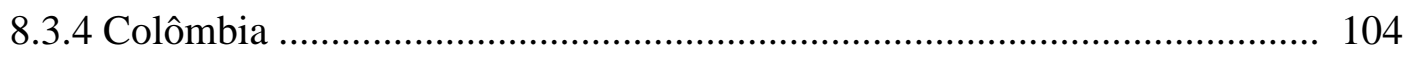

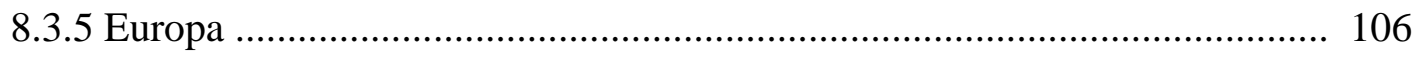

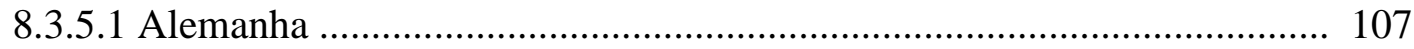

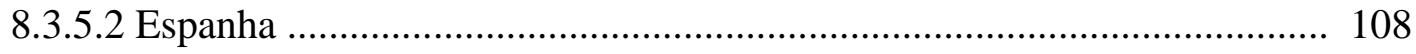

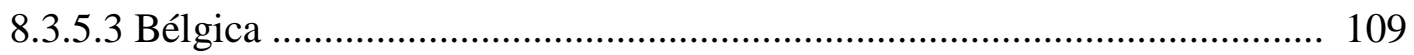

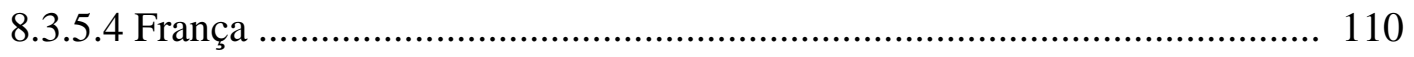

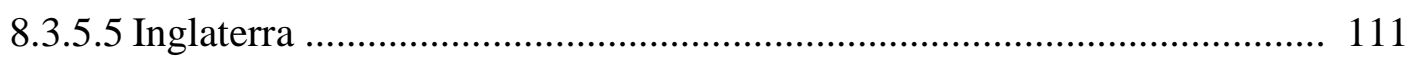

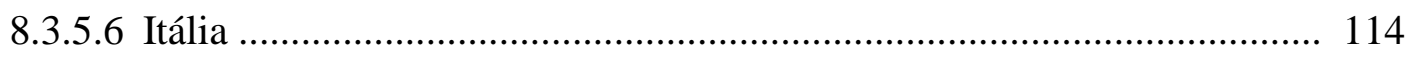

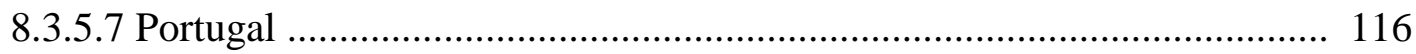

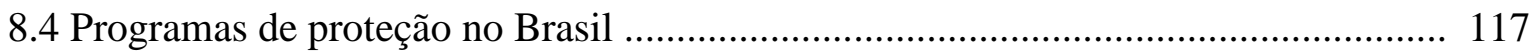

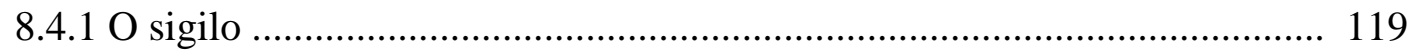

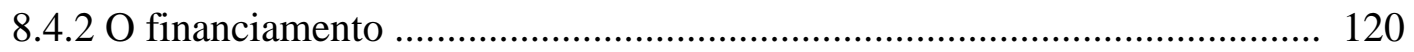

8.4.3 A prestação de contas ...................................................................... 120

8.4.4 Aspectos jurídicos não penais relacionados com o programa de

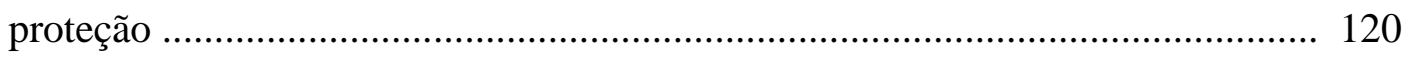

8.4.4.1 Contrato de trabalho ............................................................. 121

8.4.4.2 Existência de processos........................................................... 122 


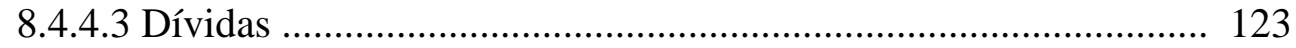

8.4.4.4 Patrimônio ......................................................................... 123

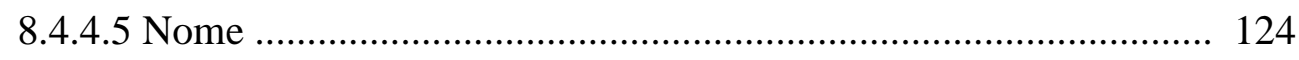

9 DELAÇÃO PREMIADA E PROTEÇÃO AO RÉU COLABORADOR .................... 125

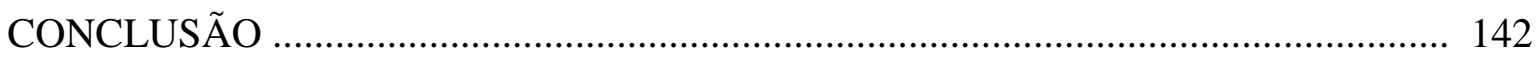

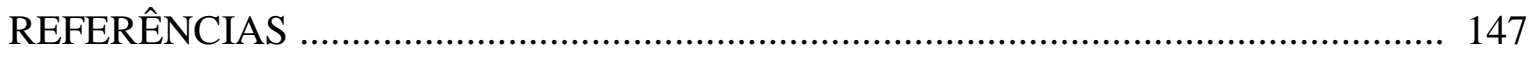




\title{
INTRODUÇÃO
}

\begin{abstract}
"Há seis meses divido um apartamento com um colega que não conhece meu passado. Digo que sou separado e sem filhos. Minha família não pode me ligar. Sou eu quem ligo. Estou sempre fugindo de quem não conheço. Você começa a fazer amizade, as pessoas querem saber mais e você tem de se afastar. É frustrante. Ainda sofro com o medo. Preciso trazer minha família, mas não sei como. Voltei lá uma única vez, mas sei que fui imprudente. Será difícil voltar à vida normal.” J.D.

"Sinto falta de minha mãe e de meu cachorro, mas não me arrependo. A violência é grande porque muita gente não acredita que possa mudar de vida trabalhando e estudando e se revolta com isso. Existe muita gente que tem medo de denunciar e outras pessoas que querem fazer justiça com as próprias mãos. Preferi colaborar de outra maneira. Só espero contribuir para diminuir a impunidade.” E.M.P.
\end{abstract}

(Relatos de testemunhas protegidas, Revista Época, ago. 1998)

O tema eleito ${ }^{1}$ começou a ser pensado durante a judicatura nas primeiras entrâncias da magistratura bandeirante, quando, em regra, o magistrado encontra várias dificuldades para alcançar e estabelecer uma consciência absolutamente tranquila para aplicação da lei penal.

O juiz é participante ativo das relações jurídico-penais no dia a dia e conhecedor da pequena eficiência do processo penal em face dos seus principais escopos, o que torna, por vezes, frustrante o trabalho incessante sem resultados favoráveis e efetivos em favor do interesse público.

Em princípio pode-se pensar que a eficácia prática do processo esteja ligada somente à celeridade processual, característica não encontrada no instrumento estatal de solução de controvérsias. Ledo engano. A efetividade do processo consiste em procurar soluções para a frustrante ineficácia prática da tutela jurisdicional ${ }^{2}$. Processo efetivo é

\footnotetext{
${ }^{1}$ Não no formato que tem hoje, mas, de forma grosseira, sobre a efetividade do provimento jurisdicional.

2 BEDAQUE, José Roberto dos Santos. Efetividade do processo e técnica processual. 2. ed. São Paulo: Malheiros, 2007. p. 31. O autor salienta que são inúmeros os óbices ao alcance do processo ideal e que a doutrina vem buscando eliminá-los. Trata-se de "O processo ideal, talvez ainda não encontrado" (ibidem, loc. cit.). Constitui perigosa ilusão pensar que o simples fato de conferir ao processo celeridade será suficiente para alcançar a tão almejada efetividade. É inegável a necessidade de reduzir a demora, mas não se pode fazê-lo em detrimento do mínimo de segurança, valor também essencial ao processo justo (BEDAQUE, José Roberto dos Santos, op. cit., p. 49).
} 
aquele que alcança o equilíbrio entre os valores segurança e celeridade trazendo ao mundo das partes o resultado material desejado ${ }^{3}$, com pacificação social.

Dinamarco analisa o escopo do processo do ponto de vista do poder do Estado de conduzir e organizar a sociedade e, por esse aspecto, define que tanto a função jurisdicional, quanto a legislativa estão ligadas pela unidade do escopo fundamental, qual seja, produzir "paz social"".

Em vista disso, a eliminação do conflito sem um critério necessário de justiça equivale ao incentivo das decepções no seio da sociedade, mantendo o estado anímico de insatisfação que foi o móvel da busca pela tutela jurisdicional ${ }^{5}$.

O processo penal é, em verdade, cruel para o juiz, na medida em que não possibilita conhecimento total da situação fática. Significa dizer: o juiz deve informar o que ocorreu, consubstanciar o fato à norma legal e aplicar a lei sem, no entanto, saber inteiramente da verdade. Ressalte-se que, aliás, a verdade absoluta é inatingível e, assim, por mais que a instrução processual esteja consubstanciada, nunca se alcançará no processo penal o conhecimento absoluto do que de fato ocorreu. Faz-se, pois, necessário que a prova apresentada chegue o mais próximo possível a fim de estabelecer critérios mínimos de conhecimento para a condenação ${ }^{6}$. É preciso buscar a verdade dos atos até para explicar a justiça da decisão ${ }^{7}$.

\footnotetext{
${ }^{3}$ BEDAQUE, José Roberto dos Santos. Efetividade do processo e técnica processual, p. 49.

${ }^{4}$ DINAMARCO, Cândido Rangel. A instrumentalidade do processo. 13. ed. São Paulo: Malheiros, 2008. p. 188.

${ }^{5}$ Ibidem, p. 347.

6 "Mesmo que se aceite a impossibilidade de se atingir um conhecimento absoluto ou uma verdade incontestável dos fatos, não é possível abrir mão da busca da verdade" (BADARÓ, Gustavo Henrique Righi Ivahy. Ônus da prova no processo penal. São Paulo: RT, 2003. p. 24). Com amparo em Ricci, escreveu Antonio Laronga: "Il problema della ricerca della verità processuale è stato studiato come rapporti tra verità giudiziale e funzione del processo. Su questo tema è stato detto e scritto, e non è assolutamente possibile riprendere, neppure per sommi capi, le varie posizioni della dottrina sull'argomento. Appare comunque evidente, oggi più che mai, la bontà dell'osservazione secondo cui l'impossibilità di raggiungere la verità assoluta, intesa cioè come 'corrispondenza assoluta di una descrizione allo stato di cose del mondo reale', non contraddice affatto l'idea del processo inteso come strumento volto all'accertamento della verità", (LARONGA, Antonio. Le prove atipiche nel processo penale. Padova: Cedam, 2002. p. 1-2).

7 "Existen en cambio buenas razones para adoptar una actitud de optimismo racionalista en el plano metodológico, es decir, como criterio de análisis. La principal de esas razones, como se ha dicho en su momento, es que es necesario situar la determinación verdadera de los hechos entre los objetivos institucionales del proceso, dado que sin esta hipótesis es casi imposible explicar racionalmente en qué consiste la justicia de la decisión” (TARUFFO, Michele. La prueba de los hechos. 2. ed. Madrid: Trotta, 2005. p. 168). Ensina, ainda, Tornaghi, que pouco importa que o réu abra mão de sua defesa ou que sejam convergentes os entendimentos das partes. A transigência das partes, em matéria de prova, não autoriza o juiz a concordar e deixar de pesquisar em busca da verdade. No feito criminal, os fatos incontroversos também serão objeto de indagação pelo juiz, contrariando a assertiva de Carnelutti: "não cabe no conceito de prova o procedimento pelo qual se descobre uma verdade não afirmada, mas sim aquele com que se demonstra uma
} 
Nos termos usados por Malatesta, a prova é meio pelo qual o espírito humano se apodera da verdade, sendo eficaz quando induz o espírito nessa crença. O resultado deve atribuir certeza, que é crença na percepção da conformidade da noção ideológica com a realidade ${ }^{8}$.

O mesmo autor ensina que o fim supremo do processo é a verificação da ocorrência do delito em sua individualidade subjetiva e objetiva ${ }^{9}$. O juiz, em razão disso, deve ser convencido pela prova, eis que é a criminalidade que não se pode afirmar, quando propriamente e bem verificada ${ }^{10}$.

Em razão disso, impossível admitir depoimentos que visivelmente são permeados pelo receio da vingança, pelo medo justificado e pelo constrangimento inevitável de testemunhas.

verdade asseverada" (TORNAGHI, Hélio. Curso de processo penal. São Paulo: Saraiva, 1983. p. 273). Sobre a questão da verdade, também escreve Augusto do Amaral: "O processo penal - instrumento ínsito ao estado constitucional de garantia pública da inocência, segundo Ferrajoli, emerge como um manancial para o convencimento do magistrado, serve a um modo de elaboração de um estado psíquico que fará o juiz ao final aderir à prova limitadamente produzida. Resultado do princípio da necessidade, liga-se onticamente ao trinômio delito-pena-processo, permite um diferimento adequado às pulsões de evidência contidas de imediato numa hipótese acusatória, na mesma medida em que se traduz num estado de pena sui generis. (...) Se a decisão judicial precisa para se tornar válida também fundar-se em algo, ter seu lastro de fundamentação em alguma representação que chegue a nós com algum sentido de realidade desde um percurso probatório legítimo, pouco importará a esta dimensão termos isso por nome de verdade ou não. (...) Com a mesma precisão, ingenuidade seria pensar que não há um certa vontade de verdade nisso tudo, todavia que não se fique refém desta situação, muito menos que, diante disto, estejamos automaticamente relegitimando uma nova idolatria pela verdade e sua colheita 'tortuosa'. (...) Certo que o processo penal não deve se orientar para a busca, pela determinação da verdade, mas que existem elementos trazidos com força de produzir uma realidade, senão ao futuro ao menos, não há como negar" (AMARAL, Augusto Jobim do. Algumas (re)descrições sobre a verdade no processo penal. Boletim do Instituto Brasileiro de Ciências Criminais, São Paulo, Ibccrim, set. 2009).

${ }^{8}$ MALATESTA, Nicola Framarino dei. A lógica das provas em matéria criminal. São Paulo: Saraiva, 1960. v. I, p. 20.

${ }^{9}$ Afirma ainda Malatesta: "Todo processo penal, no que respeita ao conjunto das provas, só tem importância do ponto de vista da certeza do delito, alcançada ou não, pois que qualquer juízo não se pode resolver senão numa condenação ou numa absolvição, e é precisamente a certeza conquistada do delito que legitima a condenação, como é a dívida, ou, por outras palavras, a não conquistada certeza do delito, que obriga à absolvição. O objeto principal da crítica é, portanto, indagar como, da prova, pode legitimamente nascer a certeza do delito; ou, em outros termos, o estudo das provas de certeza" (ibidem, p. 88).

${ }^{10}$ Ora, diz Malatesta, que "é preciso não esquecer que é em nome da consciência social que se exerce a justiça punitiva; é nesta consciência social que reside a legitimação do direito de punir; pune-se para destruir a perturbação social que produz o delito. Por tudo isso, compreende-se que a certeza moral do juiz, a certeza da criminalidade, para ser fundamento legítimo da condenação, deve encontrar apoio na consciência social. A contradição entre a consciência social e a do juiz deve levar sempre à absolvição, e jamais à condenação. Se o juiz, embora sentindo-se pessoalmente convicto da culpabilidade do acusado, sente que as suas razões não são tais que possam gerar igual convicção em qualquer outro cidadão razoável e desinteressado, deve absolver. (...) O juiz só pode, julgando legítimo o seu convencimento, condenar legitimamente, quando entenda que os fatos e as provas submetidas à sua apreciação, ao serem-no à apreciação desinteressada de qualquer outro cidadão razoável, produziriam também neste, aquela certeza, que produziram no seu espírito" (ibidem, p. 56-57). 
É cediço que a situação mais comum consiste na prova testemunhal como única fonte de conhecimento do juiz da situação dos fatos e não raro ele se confronta com depoimentos das pessoas mais simples da comunidade e que vivem nas cercanias do local do crime. É verdade que o desenvolvimento das descobertas tecnológicas trazem, também ao mundo da investigação criminal, vários instrumentos que contribuem para se descobrir a realidade dos fatos. Marcelo Mendroni assevera até que o futuro do processo penal está desenhado com o arrefecimento da necessidade da prova testemunhal em detrimento das novas técnicas científicas ${ }^{11}$. Toda essa gama de técnicas científicas necessárias para evitar a prova testemunhal ou, pelo menos, para torná-la complementária, está, todavia, longe de ocorrer, em especial no Brasil, onde o investimento público é irrisório ou quase inexistente no campo da inteligência e da investigação. Além disso, a prova testemunhal não será nunca dispensada, pois existirão situações absolutamente invisíveis às máquinas, por mais desenvolvidas que sejam ${ }^{12}$.

Relevante também é assinalar a fragilidade da prova testemunhal, muitas vezes equivocada. Não sem razão essa é chamada de a "prostituta das provas"13, pois os esclarecimentos trazidos ao processo podem consistir em uma versão inverídica dos fatos, às vezes por dolo, outras pela interpretação equivocada da cena delitiva. É sabido que muitos fatores - como a rapidez da ocorrência, o nervosismo, o cansaço, a falta de visão perfeita - podem atrapalhar o exato entendimento sobre a verdade dos fatos ${ }^{14}$.

\footnotetext{
11 "Mais provas técnicas e menos provas testemunhais. Assim está desenhado o futuro do processo penal. As ciências auxiliares da justiça se aprimoram a cada dia, de forma a proporcionar aos operadores do direito maior certeza a respeito da existência de fatos criminosos. Exames de DNA, grafotécnicos, de comparação de materiais, de reconhecimento de vozes, documentoscópicos e outros são cada vez mais utilizados para a comprovação de fatos. Microcâmeras e interceptadores de conversas atestam a existência de diálogos e encontros de pessoas. A cada passo da evolução a prova testemunhal torna-se mais complementária e menos incisiva para a formação do contexto probatório do processo criminal. A prova testemunhal torna-se, por assim dizer, prova coadjuvante do processo. Essa é a tendência probatória do processo penal moderno" (MENDRONI, Marcelo Batlouni. Crime organizado - aspectos gerais e mecanismos legais. 2. ed. São Paulo: Atlas. 2007. p. 89).

${ }^{12}$ Ensina Scarance Fernandes que, na maioria das vezes, a verificação do crime e da autoria depende de depoimentos testemunhais (FERNANDES, Antonio Scarance. Processo penal constitucional. 4. ed. São Paulo: RT, 2005. p. 80/81).

${ }^{13}$ ARANHA, Adalberto José Q. T. de Camargo. Da prova no processo penal. 7. ed. São Paulo: Saraiva, 2006. p. 157.

${ }^{14}$ MENDRONI, Marcelo Batlouni, op. cit., p. 90. Também é possível citar Adalberto Aranha, que menciona o modo pelo qual a testemunha viu o fato que deve narrar (distância, ângulo, estado emocional), sua opinião pessoal sobre o fato e os envolvidos (repugnância ou aceitação, amigo ou inimigo etc.) a maneira pela qual lhe são feitas as perguntas (impositiva ou com liberdade) e o estado emocional quando de seu depoimento (ARANHA, Adalberto José, op. cit., loc. cit.).
} 
A prova testemunhal tem, de fato, valor relativo e diretamente proporcional ao grau de confiabilidade transmitido ao juiz pelo depoente e pode ser adversária da verdade. $\mathrm{O}$ seu valor deve ser aferido em cada caso ${ }^{15}$.

É inerente à natureza humana acreditar nas palavras ditas, até mesmo como certeza histórica, caso contrário não haveria livros de história e nem mesmo se acreditaria na existência de satélites gravitando no espaço ou na capacidade gigantesca dos nanoelementos produzidos pela atual tecnologia. $\mathrm{O}$ testemunho é a fonte por excelência da certeza histórica $^{16}$.

O ritual de imprensa se baseia na transferência de informações que nada mais são do que depoimentos jornalísticos, cuja credibilidade é diretamente proporcional à idoneidade do veículo.

A despeito das fragilidades apontadas, a prova testemunhal é, ainda, necessária e muitas vezes a única fonte de certeza para eventual condenação do criminoso, não sendo possível ignorar sua importância no julgamento dos fatos.

Volta-se, então, ao eventual prejuízo causado ao contexto probatório quando houver receio justificado da testemunha em contar o que sabe, como é cediço, em razão da conhecida agressividade característica dos "guetos" de pobreza deste País.

E não é só. O aumento da criminalidade é estampado na imprensa como um "fenômeno terrificante" $" 17$, com o objetivo claro de "venda" da notícia, mas que estabelece um efeito secundário deletério, qual seja, a angústia popular decorrente do sentimento de

\footnotetext{
${ }^{15}$ Além disso, a prova colhida por uma só testemunha não pode ser considerada (ARANHA, Adalberto José Q. T. de Camargo. Da prova no processo penal, p. 157).

${ }^{16} \mathrm{Em}$ defesa da prova testemunhal, Tornaghi assinala que a finalidade da prova testemunhal é buscar a verdade a respeito de determinados fatos e, apesar de certa desconfiança, essa forma tem atravessado os séculos impondo-se nos mais variados tipos de procedimentos em todos os povos. Todos os operadores do direito procuram o aperfeiçoamento do procedimento para a distribuição exata de justiça e, em que pese ser tema de discussão, os defeitos da prova testemunhal nunca chegaram ao ponto de excluí-la, pois isso seria desprezar poderoso instrumento de investigação e, por vezes, o único de que é possível dispor. "A humanidade erraria se proscrevesse as coisas boas apenas pelo perigo decorrente de seu mau uso", assevera o autor (TORNAGHI, Hélio. Curso de processo penal, p. 397). Além disso, o conhecimento cada dia maior das regras de psicologia experimental, de crítica histórica dentre outras, torna progressivamente mais seguro e mais facilmente avaliável o testemunho (ibidem, loc. cit.).

${ }^{17}$ BECK, Francis Rafael. Perspectivas de controle ao crime organizado e crítica à flexibilização das garantias. São Paulo: Ibccrim, 2004. p. 93.
} 
medo, da necessidade de segurança e do inevitável receio de envolvimento, ainda que seja como simples testemunha de um fato criminoso ${ }^{18}$.

A prova testemunhal é, sem dúvida, fonte de prova muito importante no processo penal e deve ser preservado e cultivado no sentido de possibilitar à testemunha a liberdade de manifestação e de esclarecimento. Sem isso, o processo penal fica prejudicado, assim como a aplicação da lei penal, e a segurança pública é fragilizada.

Em meio a esse conflito, surge no Brasil o mecanismo da proteção de testemunhas, instituto já existente em outros ordenamentos estrangeiros. Começa muito tímido, com um programa no Estado do Pernambuco, mas de forma insipiente, sem recursos e absolutamente dependente de pessoas devotadas à causa, mais pelo altruísmo à questão jurídica e de segurança pública.

Em seguida, o instituto ganha contornos legislativos e outros programas vão se formando para, por fim, alcançar a maioria dos estados brasileiros ${ }^{19}$ e garantir, ainda que de maneira parcial e por conta do altruísmo das pessoas envolvidas, a segurança da testemunha e a efetividade do processo penal.

A vontade de alcançar a solenidade da verdade - e esse deve ser o objetivo do operador do direito - leva este trabalho de pesquisa a encarar o instituto da prova testemunhal e, por consequência, da proteção de vítimas e testemunhas como um dos caminhos necessários para o cumprimento da lei penal ou, bem assim, como mecanismo de efetividade do processo penal.

Evidente que não se pode pensar tudo isso e, ao mesmo tempo, olvidar-se das

\footnotetext{
18 Segundo Mendroni: "Se a condição das testemunhas em um processo penal comum já é relativamente delicada, tratando-se de situação em que se atestam circunstâncias que se refiram a pessoas ligadas ou supostamente ligadas a organizações criminosas, torna-se fortemente agravada. Para ser testemunha, prestar depoimento com isenção e sem temerosidade, deve a pessoa estar serena e segura dos fatos que relata. Não é possível obter-se um testemunho convincente sem proporcionar à testemunha a tranqüilidade da garantia da sua vida, integridade física e seus próximos" (MENDRONI, Marcelo Batlouni. Crime organizado - aspectos gerais e mecanismos legais, p. 92).

${ }_{19}$ Existe, hoje, um programa federal, cuja abrangência está sobre todo o território nacional e supre as omissões de alguns Estados-membros, pois são somente dezesseis estados que patrocinam o programa no formato Provita e mais um Estado (Rio Grande do Sul) em um formato diferente. O formato do programa e como é feita a execução da proteção serão melhor explicados no Capítulo 8 deste trabalho.
} 
garantias constitucionais previstas ao réu no processo penal. São as limitações do poder estatal em detrimento dos direitos assegurados para a liberdade individual ${ }^{20}$.

É da história recente que o Estado intervencionista prejudica os direitos fundamentais sem o equilíbrio necessário das garantias previstas na Constituição Federal $^{21}$. Ensina Scarance Fernandes, que houve inserção, em especial após as duas grandes guerras mundiais, de regras de cunho garantista nas leis maiores dos países, com a finalidade de impor à sociedade o "respeito aos direitos individuais", além das várias convenções internacionais firmadas nesse sentido ${ }^{22}$.

Assinala o autor pré-citado, como fundamentais, na construção do garantismo, a Declaração dos Direitos Universais do Homem, produzida na Assembleia das Nações Unidas, em 10 de dezembro de 1948; a Convenção Europeia para a Salvaguarda dos Direitos do Homem e das Liberdades Fundamentais, subscrita em Roma aos 10 de novembro de 1948; o Pacto Internacional dos Direitos Civis e Políticos adotado pela Resolução 2.200, da XXI Sessão da Assembleia Geral das Nações Unidas, de 16 de dezembro de 1966, e ratificada pelo Brasil em 24 de janeiro de 1992; a Convenção dos Direitos Humanos, também conhecida por Pacto de São José da Costa Rica, ratificada pelo Brasil em 25 de setembro de $1992^{23}$.

Impossível simplesmente ignorar todas essas regras, que formam o conjunto dos direitos e garantias individuais do Brasil, para buscar a efetividade do processo penal. $\mathrm{O}$ grande desafio é alcançar essa efetividade, sem, no entanto, deixar de cumprir tais normas de âmbito constitucional. É o equilíbrio entre as regras da segurança jurídica do devido processo legal e o curso de tempo razoável ${ }^{24}$.

\footnotetext{
${ }^{20}$ BECHARA, Fábio Ramazzini. Criminalidade organizada e procedimento diferenciado: entre eficiência e garantismo. In: COSTA, José de Faria; SILVA, Marco Antonio Marques da (Org.). Direito penal especial, processo penal e direitos fundamentais. Visão luso-brasileira. São Paulo: Quartier Latin, 2006. p. 915. Acrescenta, ainda, o autor, que somente houve restrição da liberdade individual pelo estabelecimento das inúmeras garantias, como o devido processo legal, o contraditório, a ampla defesa, a necessidade de motivação das decisões judiciais, a garantia do juiz natural, a vedação das provas ilícitas e a impossibilidade de antecipação dos efeitos da condenação.

${ }^{21}$ Importante a reflexão de que as garantias processuais impõem limites ao poder punitivo do Estado, estabelecendo os mecanismos de defesa e que não podem ser violados, ainda que para busca da verdade absoluta (PLETSCH, Natalie Ribeiro. Formação da prova no jogo processual penal. O atuar dos sujeitos e a construção da sentença. São Paulo: Ibccrim, 2007. p. 13).

${ }_{22}^{2}$ FERNANDES, Antonio Scarance. Processo penal constitucional, p. 13.

${ }^{23}$ Ibidem, p. 14.

24 ALMEIDA, José Raul Gavião de. Acesso efetivo à justiça. In: COSTA, José de Faria; SILVA, Marco Antonio Marques da (Org.). Direito penal especial, processo penal e direitos fundamentais. Visão lusobrasileira, p. 569. Acrescenta, ainda, o autor: "Nem o garantismo radical, nem o procedimento desenfreado
} 
A garantia do devido processo legal prevista na Constituição Federal brasileira é suficiente para condicionar a condenação criminal aos princípios mais comezinhos do direito, como a participação do réu em audiência ${ }^{25}$, notadamente na oitiva de testemunhas arroladas pela acusação ${ }^{26}$. Trata-se da tutela da liberdade individual que foi tolhida pelo Estado totalitário.

É pertinente lembrar, então, o princípio da proporcionalidade, pelo qual deverá o operador do direito sopesar os valores colocados em conflito, a fim de estabelecer a possibilidade plena da produção da prova, sem, no entanto, atingir os direitos fundamentais assegurados ao réu no processo penal.

O princípio da proporcionalidade limita a atuação do poder estatal em benefício da garantia do direito à liberdade, mas também equipara àquele o direito da maioria, atendendo aos interesses da investigação, procurando ajustar a obtenção das provas ao devido processo legal.

Cada vez mais os profissionais do direito processual têm buscado soluções para o estabelecimento do efetivo processo penal, e nessa busca se verifica que alguns elementos são partes integrantes da equação do problema: a difusão do crime organizado; a deficiência na instrução probatória; os mecanismos próprios para a eficiência do processo penal, em específico a proteção de testemunhas, vítimas e réus colaboradores; e a aplicação prática do instituto em face dos ordenamentos jurídicos brasileiro e estrangeiro.

atuam em benefício da Justiça" (ALMEIDA, José Raul Gavião de. Acesso efetivo à justiça. In: COSTA, José de Faria; SILVA, Marco Antonio Marques da (Org.). Direito penal especial, processo penal e direitos fundamentais. Visão luso-brasileira, p. 569).

${ }^{25}$ Ensina Scarance Fernandes: "A presença do acusado no momento da produção da prova testemunhal é essencial, sendo exigência decorrente do princípio constitucional da ampla defesa. Estando na audiência, pode ele auxiliar o advogado nas reperguntas a serem dirigidas à testemunha ouvida. Por isso, em caso de acusado preso, este deve ser requisitado, ainda que a prova testemunhal seja colhida em precatória" (FERNANDES, Antonio Scarance. Processo penal constitucional, p. 81). Acrescentaria, ainda, a necessidade do réu em participar da audiência para ver, com seus olhos, que os atos processuais são efetivamente realizados, que existem pessoas que podem confirmar, ou não, a sua participação e que a futura condenação (se for o caso) está baseada em prova lícita, produzida por meios lícitos e que não há qualquer criação fantasiosa dos fatos. É inadmissível o réu kafkiano nos dias atuais. Por óbvio, todas essas regras devem ser aplicadas levando-se em consideração vários outros fatores e essa construção também será buscada neste trabalho.

${ }^{26}$ Como se verá no Capítulo 3, em outros ordenamentos, são utilizados expedientes diferenciados para a manutenção dessas garantias. Por exemplo, nos Estados Unidos a audiência é transmitida por via de canal fechado de televisão e podem o réu e seu advogado, ao menos, ver que existe uma pessoa (ainda que escondida) prestando depoimento e que os fatos mencionados formam a prova que será o fundamento de futura condenação. Em El Salvador, como em outros tantos países, a testemunha presta seu depoimento encapuzada. 
Insta salientar que o presente trabalho não avançará no estudo de todos os mecanismos processuais para apuração de crimes praticados por organizações criminosas, limitando-se à análise do instituto específico da proteção de testemunhas e vítimas estabelecido pela Lei $\mathrm{n}^{\mathrm{o}}$ 9.807/99 e do instituto da delação premiada prevista na Lei $\mathrm{n}^{\mathrm{o}}$ 9.034/95. 


\section{NOÇÕES PRELIMINARES SOBRE A PROVA}

O termo prova tem significado oriundo do latim probatio, que significa prova, ensaio, verificação, e deriva do verbo provare (probo, as, are). Vem de probus, que conceitua o que é bom, escorreito. Ou seja, provar tem sentido em estabelecer o que é correto, mas comumente se verifica a prova como sendo o "meio pelo qual a inteligência chega à descoberta da verdade ${ }^{, 27}$ ou, como ensina Tornaghi, consiste em averiguar a verdade e formar a convicção do julgador ${ }^{28}$.

Saliente-se que há muitos significados na doutrina ${ }^{29}$, mas se conclui que sempre se busca a verdade sobre um fato, nada obstante seja objeto da prova a alegação de um fato e não o fato em si mesmo. O fato é o acontecimento propriamente dito, não comportando qualquer variação ou diferenças, dados os elementos de prova apresentados. $\mathrm{O}$ fato simplesmente existe.

Os "fatos debatidos no processo", por sua vez, são enunciados sobre os acontecimentos reais, sendo verdadeiras ou falsas as percepções dos atuantes no mundo jurídico do processo ${ }^{30}$. Em função disso, as alegações é que são objeto de prova.

Como função do processo, leciona Badaró que a relação entre o meio e o escopo do processo dependerá da concepção do processo, pois, em razão da existência de teorias negativas da possibilidade de conhecimento verdadeiro dos fatos, não é devida uma teoria pura de prova como busca da verdade. Com base no entendimento propugnado pelo autor, "a prova acaba servindo para dar uma aparência de legitimação racional para um conjunto de mecanismos teatrais cuja função é dissimular a realidade irracional e injusta da decisão judicial" ${ }^{\prime 1}$.

\footnotetext{
${ }^{27}$ BADARÓ, Gustavo Henrique Righi Ivahy. Ônus da prova no processo penal, p. 156.

${ }^{28}$ TORNAGHI, Hélio. Curso de processo penal, p. 271.

${ }^{29}$ ARANHA, Adalberto José Q. T. de Camargo. Da prova no processo penal, p. 5. Hélio Tornaghi descreve em sua obra todas essas acepções: prova como atividade probatória, ou conjunto de atos praticados para busca da verdade e convencimento do juiz; procedimento de prova, como dizem os franceses, administration de la preuve; o próprio resultado da atividade probatória, e.g., arts. 131 do CPC e 157 do CPP; ou quando o vocábulo indica qualquer elemento de convicção, pois o CPP (art. $\left.6^{\circ}\right)$ determina à autoridade policial "colher todas as provas que servirem para o esclarecimento do fato e suas circunstâncias"; e, por fim, quando se refere aos meios de prova (TORNAGHI, Hélio, op. cit., p. 272).

${ }^{30}$ BADARÓ, Gustavo Henrique Righi Ivahy, op. cit., p. 159.

${ }^{31}$ Ibidem, p. 161.
} 
Existem, em contrapartida, entendimentos sobre a prova como um elemento de persuasão, em que cada parte convence (ou procura convencer) o julgador de sua alegação e, nesse caso, a função da prova será "argumentativa”, ainda de acordo com Badaró.

Também não será possível asseverar que a prova alcance o conhecimento verdadeiro dos fatos da causa, de forma absoluta. A função da prova será, então, criar circunstâncias racionais de escolha da versão mais próxima apresentada.

Faz-se necessário, em seguida, diferenciar meio de prova e fonte de prova, como fez Carnelutti, citado por Badaró: "fontes de prova são fatos dos quais o juiz se serve para deduzir a verdade, enquanto os meios de prova são a atividade do juiz mediante a qual busca a verdade de um fato a se provar" ${ }^{\text {"32 }}$. Em razão disso, a testemunha de um fato se traduz em fonte de prova, uma vez que o juiz não tem contato com o fato probandum, mas sim com uma pessoa que lhe relatará o acontecimento. Na prova testemunhal, entre o juiz e o fato existe um elemento intermediário e o resultado da prova advém por uma atividade perceptiva e dedutiva, eis que o juiz "deduz" a verdade dos fatos por meio do relato da testemunha. As declarações da testemunha em juízo, por sua vez, se revelam como meio de prova.

Assevera Tornaghi que a expressão meio de prova é utilizada para explicar o "meio de conhecimento" e não o "meio de demonstração"33.

Na prova direta, segundo a qual o juiz tem contato imediato com o fato a ser provado, não há atividade dedutiva, bastando a simples percepção e, nesse caso, o juiz recebe como meio de prova. Segundo Badaró, ${ }^{34}$ são exemplos a inspeção judicial como meio de prova e prova testemunhal como fonte de prova.

Verifica-se, portanto, que prova testemunhal é "fonte de prova" e não "meio de prova".

É finalidade precípua da prova o convencimento do julgador (iudici fit probatio), eis que a ele a prova será dirigida com a finalidade de que efetue sua avaliação. No procedimento inquisitório não haverá nenhum outro objetivo à prova, enquanto no

\footnotetext{
${ }^{32}$ CARNELUTTI, Francesco. La prova civile. In: BADARÓ, Gustavo Henrique Righi Ivahy. Ônus da prova no processo penal, p. 164.

${ }^{33}$ TORNAGHI, Hélio. Curso de processo penal, p. 278.

${ }^{34}$ BADARÓ, Gustavo Henrique Righi Ivahy, op. cit., p. 164.
} 
procedimento acusatório ainda se poderá atribuir à prova a demonstração, pelas partes, até mesmo uma para a outra, da verdade de suas alegações ${ }^{35}$.

A par disso, merece destaque, no direito processual brasileiro, o princípio da comunhão das provas, que significa não pertencer a prova exclusivamente ao julgador, pois uma vez no mundo dos autos, pode ser utilizada, desde que existente o permissivo legal, por qualquer dos sujeitos da relação processual. Resulta disso a possibilidade de reperguntas às testemunhas, ainda que arroladas pelo adverso ${ }^{36}$.

É verdade que esse entendimento poderia impor a obrigatoriedade de concordância de ambas as partes para eventual desistência de produção por aquele que efetuou inicialmente o pedido. Entretanto, a comunhão das provas faz alusão à prova produzida e não à postulação da prova.

São três momentos importantes: o da postulação ou pedido de produção de provas (e.g., apresentação do rol de testemunhas na denúncia/queixa ou resposta) e seu deferimento ou não pelo juiz, o da produção propriamente dita e o da avaliação da prova ${ }^{37}$.

Enquanto não houver a passagem do primeiro para o segundo momento, a prova não terá sido produzida e não seria razoável exigir a concordância de ambas as partes para eventual desistência daquele que postulou a prova.

Entendimento contrário demonstra Hélio Tornaghi, que assevera a necessidade de consentimento da parte contrária, o que ocorre de forma tácita na maioria das vezes ${ }^{38}$.

\footnotetext{
35 TORNAGHI, Hélio. Curso de processo penal, p. 272.

${ }^{36}$ É a regra testes et documenta per productionem fiunt communia (testemunhos e documentos, uma vez produzidos, tornam-se comuns) (ibidem, p. 275).

${ }^{37}$ Explica Tourinho, que o procedimento probatório se divide em quatro momentos: proposição ou indicação; admissão; produção; e valoração (TOURINHO FILHO, Fernando da Costa. Processo penal. São Paulo: Saraiva, 1990. v. 3, p. 216). São, na verdade, variáveis as classificações feitas pela doutrina.

38 TORNAGHI, Hélio, op. cit., loc. cit.
} 


\section{A PROVA TESTEMUNHAL}

A prova testemunhal é a fonte de prova pela qual o julgador obtém, por meio de depoimento verbal de pessoa, ${ }^{39}$ o conhecimento dos fatos que são objeto do litígio. As testemunhas são terceiros chamados a depor sobre suas percepções sensoriais ${ }^{40}$, ou seja, sobre o que viu e/ou ouviu, assim como sobre outras percepções obtidas dos demais sentidos como olfato ou tato.

Define Frederico Marques que essas percepções se referem aos fatos que constituem objeto do litígio penal e não cabe à testemunha dar "parecer" ou "opinião" a respeito da quaestio juris e "tampouco manifestar suas apreciações pessoais, salvo quando inseparáveis do fato" (art. 213, CPP, sem grifos no original) ${ }^{41}$.

Em suma, a testemunha é a pessoa, estranha ao feito, que levará ao julgador a declaração dos fatos que tem conhecimento acerca dos limites do que se litiga.

Escorreita é a definição elaborada por Borges da Rosa: “Testemunha, no sentido próprio da palavra, é a pessoa chamada a depor acerca de determinado fato. Testemunhar, do latim testari, é o mesmo que afirmar, mostrar, atestando; daí testemunha, testi - ou testemunho, testemonium, significando genericamente prova". O termo latino testibus significa dar fé da veracidade de um fato ${ }^{42}$.

\footnotetext{
${ }^{39}$ Testemunha é todo homem, estranho ao feito e equidistante às partes, capaz de depor, chamado ao processo para falar sobre fatos caídos sob seus sentidos e relativos ao objeto do litígio. É a pessoa idônea, diferente das partes, convocada pelo juiz, por iniciativa própria ou a pedido das partes, para depor em juízo sobre fatos sabidos e concernentes à causa (ARANHA, Adalberto José. Da prova no processo penal, p. 158). 40 "As testemunhas são os olhos e os ouvidos da justiça. Desde que os homens existem e desde que têm a pretensão de fazer justiça hão se valido das testemunhas como o mais fácil e comum meio de prova; sua importância no campo criminal é considerável; frequentemente é a única base das acusações". Sábias palavras de Bentham, reproduzindo, numa essência, todo o significado da prova testemunhal (ARANHA, Adalberto José, op. cit., p. 156).

${ }^{41}$ MARQUES, José Frederico. Elementos de direito processual penal. São Paulo: Millenium, 2003. p. 403. Acrescenta, ainda, Adalberto Aranha, que a testemunha não emite opinião nem fala sobre conjeturas, mas apenas reproduz fatos percebidos por seus sentidos: presenciou a cena (vista), ouviu dois disparos (audição), o cheiro era de sangue (olfato), a arma ainda estava quente (tato), era grande o teor alcoólico (paladar) (ARANHA, Adalberto José, op. cit., p. 159).

${ }^{42}$ ROSA, Inocêncio Borges da. Comentários ao Código de processo penal. 3. ed. São Paulo: RT, 1982. p. 315. In: DECOMAIN, Pedro Roberto. Proteção a testemunhas: redução de pena para o acusado que colabora com a investigação criminal. Revista do Ministério Público/Ministério Público do Estado do Rio de Janeiro, n. 12, p. 140, jul./dez. 2000.
} 
Em simples classificação, a prova testemunhal pode, quanto ao modo, ser instrumental ou judicial; no que tange ao conteúdo, direta ou indireta, e, em razão do objeto, própria ou imprópria.

Instrumentária é a testemunha chamada para reproduzir os fatos que de qualquer forma tiveram conhecimento, em específico de atos processuais que demandem a presença de testemunhas (reconhecimento de pessoas e coisas - art. 22, IV, CPP), na busca e apreensão (art. 245, § 7º, CPP) e no auto de prisão em flagrante (art. 304, § $3^{\mathrm{o}}$, CPP) ${ }^{43}$. As demais são chamadas porque pelos sentidos tiveram conhecimento de fatos relevantes acerca da imputação ou do objeto do feito.

Testemunhas diretas são as pessoas que revelam fatos que presenciaram, "reproduzindo uma sensação obtida de ciência própria", enquanto as indiretas depõem sobre fatos sabidos por terceiros ${ }^{44}$. Tornaghi, citando Manzini, lembra que testemunha indireta não é testemunha, mas sim um informante inseguro, com base no qual se alcança a verdadeira testemunha ${ }^{45}$.

Por fim, testemunha própria é a que depõe sobre o thema probandum, pois a testemunha imprópria atesta a regularidade de um ato (como testemunha instrumentária) ${ }^{46}$.

O depoimento testemunhal se reveste dos caracteres de judicialidade, oralidade, objetividade e retrospectividade. Judicialidade porque se trata de prova produzida somente perante a autoridade judiciária. Oralidade também é exigida pela legislação processual porque o escrito se torna um documento, permitindo-se, excepcionalmente, consulta breve a apontamentos (art. 204, parágrafo único, CPP). A objetividade do depoimento testemunhal cinge-se na limitação imposta à testemunha de não emitir opinião, parecer ou fazer conjeturas, salvo, evidentemente, quando inseparáveis da narrativa do fato (art. 213, CPP). Por último, retrospectividade, que se baseia na declaração de acontecimentos pretéritos, ainda que haja conhecimento técnico para alguma avaliação ${ }^{47}$.

Toda pessoa pode ser testemunha (art. 202, CPP), mas, em razão de função, ministério, ofício ou profissão, algumas pessoas devem guardar segredo e, por

\footnotetext{
${ }^{43}$ ARANHA, Adalberto José. Da prova no processo penal, p. 160.

${ }^{44}$ Ibidem, loc. cit.

${ }^{45}$ TORNAGHI, Hélio. Curso de processo penal, p. 398.

${ }^{46}$ ARANHA, Adalberto José, op. cit., p. 161.

47 TORNAGHI, Hélio, op. cit., p. 399-401.
} 
consequência, ficam proibidas de depor sobre determinados fatos (art. 207, CPP). São as testemunhas incapazes ou impedidas.

Outras, entretanto, serão ouvidas, mas não haverá compromisso de falar a verdade (art. 208, CPP), dada a proximidade com as partes ou com os fatos, como é o caso dos ascendentes, descendentes e afins em linha reta, o cônjuge, ainda que depois da separação, irmão, pai, mãe ou filho adotivo do acusado (art. 206, CPP), assim também os deficientes mentais e menores de 14 anos (art. 208, CPP).

No caso em tela, trata-se das chamadas testemunhas inidôneas, suspeitas ou defeituosas, que por motivos psíquicos ou morais não farão de seus depoimentos atos perfeitos na busca da verdade. Por vezes não querem faltar com a verdade, mas, pelos motivos elencados na lei, está justificada a diminuição ou exclusão da credibilidade de sua narrativa $^{48}$.

A testemunha "suspeita de parcialidade, ou indigna de fé" (art. 214, CPP) não será, assim, dispensada do depoimento, nem tampouco lhe será dispensado o compromisso de falar a verdade. É, no entanto, cabível a contradita com o objetivo de orientar o julgador na avaliação da prova em vista dos motivos que lhe retirem a isenção.

Testemunhas referidas são aquelas citadas por outras em depoimento judicial e podem ser ouvidas a critério do juiz, que também poderá convocar outras que entenda convenientes ao esclarecimento da verdade (art. 209, CPP).

São obrigações das testemunhas: comparecer em juízo, no dia, local e horário previamente determinados para o depoimento (art. 218, CPP); prestar depoimento (art.

\footnotetext{
${ }^{48}$ ARANHA, Adalberto José. Da prova no processo penal, p. 165. O mesmo autor explica que existem quatro sistemas que regulam diferentemente as testemunhas suspeitas ou inidôneas. O primeiro, mais rígido, adotado na França, estabelece os motivos da suspeição e impedem o depoimento. Na Argentina e na Espanha, há um sistema menos rigoroso, pelo qual, embora descritos os motivos ensejadores na legislação processual, não impedem o depoimento e o julgador confere a esses depoimentos o valor que entender devido. Um terceiro sistema é adotado pelas legislações da Alemanha, Áustria e Reino Unido, nas quais não existe qualquer alusão à testemunha suspeita e o julgador é o encarregado de apreciar eventuais alegações de inidoneidade. Por último, ressalta-se o sistema adotado pela legislação brasileira, em que a existência de causas de suspeição não se apresenta com enumeração taxativa e cabe ao juiz avaliar as causas invocadas quando as testemunhas forem contraditadas (ibidem, p. 166). Descreve o art. 214 do Código de Processo Penal: "Antes de iniciado o depoimento, as partes poderão contraditar a testemunha ou argüir circunstâncias ou defeitos, que a tornem suspeita de parcialidade, ou indigna de fé. O juiz fará consignar a contradita ou argüição e a resposta da testemunha, mas só excluirá a testemunha ou não lhe deferirá compromisso nos casos previstos nos arts. 207 e 208.".
} 
206, CPP); e dizer a verdade a respeito do que souber ou lhe for perguntado (art. 203, CPP).

Adalberto Aranha também estabelece como obrigação da testemunha a de identificar-se, como corolário do princípio da ampla defesa ${ }^{49}$. Evidente que este item deverá ser desenvolvido com mais profundidade neste trabalho, dada a necessidade de se preservar a testemunha como forma de assegurar sua proteção ${ }^{50}$.

A ausência da testemunha no horário determinado acarretará a sua condução coercitiva, podendo o juiz requisitar a força policial (art. 218, CPP). O magistrado poderá, ainda, aplicar à testemunha faltosa multa pecuniária, sem prejuízo do processo penal por desobediência e condenação às custas das diligências (art. 219, CPP). São exceções e se aplicam diferentemente a esta regra as hipóteses de testemunhas residentes fora do território de competência daquele Juízo, caso em que serão ouvidas por carta precatória (art. 222, CPP), os impossibilitados fisicamente, que serão ouvidos onde estiverem (art. 220, CPP) e os ocupantes de cargos, cujo rol está expresso no artigo 221 do Código de Processo Penal ${ }^{51}$.

A testemunha também deverá prestar depoimento, ou seja, "não poderá eximir-se da obrigação de depor" (art. 206, CPP), muito embora não haja sanção específica. Será caso de se aplicar a sanção genérica do crime de desobediência (art. 330, CP). Há quem defina, no descumprimento desse dever, a "omissão da verdade", caracterizando-se, com isso, o delito tipificado no artigo 342 do Código Penal, qual seja, o crime de falso testemunho ${ }^{52}$.

Por fim, em relação às obrigações, antes do início da inquirição, o juiz advertirá a testemunha que está prestando seu depoimento em juízo e que deve falar a verdade, não podendo a respeito dela mentir ou calar-se sob pena de incorrer no crime de falso testemunho (art. 203, CPP, e art. 342, CP).

\footnotetext{
${ }^{49}$ A testemunha tem a obrigação de, ao início de seu depoimento, qualificar-se, indicando seu nome, idade, estado civil, residência, profissão, local onde exerce sua atividade, se há relação de parentesco ou possível relacionamento com as partes. Deverá, portanto, indicar não só os elementos identificadores como também explicitar o grau de relacionamento com os envolvidos no processo (ARANHA, Adalberto José. Da prova no processo penal, p. 168).

${ }^{50}$ Vejam-se observações ao longo deste Capítulo.

${ }^{51}$ ARANHA, Adalberto José, op. cit., loc. cit.

${ }^{52}$ Ibidem, loc. cit.
} 
Vítima não é testemunha, pois não está na mesma condição daquele que simplesmente presenciou, ouviu ou de alguma outra forma teve ciência dos fatos delituosos.

Com amparo em Heleno Fragoso, o autor Pedro Roberto Decomain assinala que a vítima é o titular do bem jurídico ofendido. Trata-se do sujeito passivo do crime; ele não se confunde com o objeto material do crime, que é a coisa ou pessoa sobre a qual recai a ação delituosa. Porém, no caso do homicídio, v.g., o sujeito passivo se confunde com o objeto material $^{53}$.

Para Tourinho, ofendido ou vítima é o titular do direito lesado ou simplesmente posto em perigo, ou seja, é quem sofre a ação violatória da norma penal ${ }^{54}$.

Insta estabelecer que a vítima não é testemunha, muito embora, para os fins da proteção que consiste no objeto central deste trabalho, isso não faça diferença, como se verá adiante.

Antes da reforma de 2008, com as alterações trazidas pela Lei n⿳o 11.690 , o Código de Processo Penal já previa um capítulo separado para as "perguntas do ofendido", deixando claro que fazia distinção entre ofendido e testemunha. Essa distinção agora está muito mais acentuada, dado que estabeleceu verdadeiro procedimento para a colheita da prova oral da vítima, conforme estudo apresentado no capítulo seguinte, que trata das inovações legislativas no tocante à prova.

De qualquer forma, para justificar, verifica-se a nova descrição do artigo 201 do Código de Processo Penal, o qual determina atenção à eventual necessidade de atendimento psicossocial, assistência jurídica e de saúde, além de se preservar a intimidade, a vida privada, a honra e a imagem.

Isso traz inúmeras consequências ao procedimento, pois se vítima não é testemunha e, "sempre que possível, o ofendido será qualificado e perguntado sobre as circunstâncias da infração" (art. 201, caput, CPP), não deve ser contada como testemunha para a limitação do número legal do rol a ser apresentado na denúncia ou na defesa preliminar.

\footnotetext{
${ }^{53}$ DECOMAIN, Pedro Roberto. Proteção a testemunhas: redução de pena para o acusado que colabora com a investigação criminal. Revista do Ministério Público/Ministério Público do Estado do Rio de Janeiro, n. 12, p. 140.

${ }^{54}$ TOURINHO FILHO, Fernando. Processo penal, p. 257.
} 
Com isso, no procedimento comum ordinário, além das oito testemunhas passíveis de serem arroladas, também será ouvido o ofendido. No caso do procedimento sumário, serão cinco testemunhas e mais a vítima.

A vítima não presta compromisso e nem está obrigada a dizer a verdade. O compromisso legal somente será efetuado em relação às testemunhas, não sendo sujeito ativo do crime de falso testemunho, o que traz inevitável contorno diferenciado na avaliação da prova. Ensina Tourinho Filho que:

“(..) a vítima do crime, em geral, é quem pode esclarecer,
suficientemente, como e de que maneira teria ele ocorrido. Foi ela quem
sofreu a ação delituosa e, por isso mesmo, estará apta a prestar os
necessários esclarecimentos à Justiça. Sendo assim, qual seria o valor
probatório de suas palavras? Prima facie, parecerá que suas declarações
devem ser aceitas sem reservas, pois ninguém melhor que a vítima para
esclarecer o ocorrido. É de se ponderar, entretanto, que aquele que foi
objeto material do crime, levado pela paixão, pelo ódio, pelo
ressentimento e até mesmo pela emoção, procura narrar os fatos como lhe
pareçam convenientes; às vezes, a emoção causada pela cena delituosa é
tão intensa, que o ofendido, julgando estar narrando com fidelidade,
omite ou acrescenta circunstâncias, desvirtuando os fatos. (...) Desse
modo, a sua palavra deve ser aceita com reservas, devendo o Juiz
confrontá-la com os demais elementos de convicção, por se tratar de parte
interessada no desfecho do processo." 55

Isso se aplica com mais razão agora com a descrição do artigo 387, inciso IV, do Código de Processo Penal que determina ao juiz fixar o "valor mínimo para reparação dos danos causados pela infração, considerando os prejuízos sofridos pelo ofendido" ao proferir sentença condenatória.

O tratamento dado à vítima não é, assim, o mesmo dado à testemunha em relação ao procedimento. Quando se tratar da necessidade de proteção da pessoa da vítima, no entanto, por óbvio que não será possível estabelecer a diferença do tratamento concedido às testemunhas, quiçá por estar o ofendido mais sujeito à ação violenta do acusado.

${ }^{55}$ TOURINHO FILHO, Fernando. Processo penal, p. 262. 
A importância desses relatos trazidos por testemunhas e por vítimas é indiscutível. A prova técnica, detalhada e materialmente absoluta, demonstra na maior parte das vezes a ocorrência do crime, sua materialidade, mas quase nunca traduz a autoria. A título exemplificativo, salienta-se o caso de um crime de homicídio, em que o exame necroscópico é absoluto para demonstrar a realidade da morte e sua causa (resultado lesivo e nexo de causalidade), mas que nunca poderá trazer ao Juízo a identificação do autor da conduta. A prova trazida pelos relatos de testemunhas (e vítimas em outros casos) é de fundamental importância para o deslinde da autoria, terceiro elemento necessário para a condenação. Isso ocorre, ainda que essa prova seja absolutamente falível ${ }^{56}$.

É, portanto, possível atribuir à prova testemunhal caráter de essencialidade, muito embora se tenham tantas críticas a esse meio probatório.

\footnotetext{
56 "A ciência da testemunha lhe é dada por seus sentidos, principalmente a vista e a audição, não se excluindo, entretanto, os outros, pois, em determinados casos, o paladar, o olfato e o tato lhe podem fornecer o conhecimento de um fato. É dos mais discutidos o valor do testemunho humano, sabido que nossos sentidos frequentemente nos iludem. Influem ainda diversamente a capacidade de observação e a memória, já não se falando na mendacidade que frequentemente vicia o depoimento. Como quer que seja, máxime no processo penal, é ele a prova por excelência. O crime é um fato, é um trecho da vida e, consequentemente, é, em regra, percebido por outrem. 'O depoimento - lembra Vishinski - é uma das provas mais antigas e generalizadas. Não há sistema probatório que lhe negue um lugar mais ou menos importante entre as demais provas'. Falível que é o testemunho, sujeito a vícios que o deturpam, deve merecer toda a cautela do Juiz, não apenas quanto ao conteúdo, mas também quanto à idoneidade de quem presta, o modo por que o faz, etc." (NORONHA, E. Magalhães. Curso de direito processual penal. Atualizado por Adalberto José Q. T. de Camargo Aranha. 27. ed. São Paulo: Saraiva, 1999. p. 148).
} 


\section{PRESENÇA FÍSICA DO RÉU EM AUDIÊNCIA}

É necessário refletir, ainda que en passant, sobre a circunstância da presença física do réu em audiência no momento da colheita da prova oral, dada a possibilidade de constrangimento da testemunha ou vítima.

É entendimento deste pesquisador que não paira dúvida sobre o direito do acusado em permanecer em sala de audiência ou no plenário do júri para assistir aos depoimentos de testemunhas e vítimas por se tratar de corolário do devido processo legal que prevê o direito de ampla defesa.

Assegura o artigo $5^{\circ}$, inciso LV, da Constituição Federal, aos litigantes em processo judicial ou administrativo, e aos acusados em geral, o contraditório e a ampla defesa, com os meios e recursos a esta última inerentes.

Integra o direito de defesa: conhecimento da imputação; poder contrariar a imputação inicial; acompanhar a prova produzida e fazer contraprova; defesa técnica de advogado; e duplo grau de jurisdição ${ }^{57}$. Inevitável, todavia, a possibilidade de influência dessa situação no estado de espírito do depoente. O constrangimento e o receio de vingança são inerentes à pessoa humana nessas circunstâncias.

Em razão disso, fez previsão o Código de Processo Penal da realização do ato sem a presença do acusado (ao menos sem a sua presença física), o que retira do direito de ampla defesa, o direito absoluto de o acusado acompanhar a prova produzida, ao menos pessoalmente. Ressalte-se que, aliás, não é estranha a limitação nos direitos advindos da ampla defesa em relação à prova ${ }^{58}$.

O artigo 217 do Código de Processo Penal, alterado pela Lei no 11.690/08, dispõe sobre a possibilidade de decisão, devidamente fundamentada, do magistrado em realizar a

\footnotetext{
57 BRUNO NETO, Mario Augusto. O direito em debate: breves considerações acerca do Provimento $\mathrm{n}^{\mathrm{o}}$ 32/00. Boletim Ibccrim, v. 13, n. 152, p. 14-15, jul. 2005.

${ }^{58} \mathrm{O}$ direito das partes à introdução, no processo, das provas que entendam úteis e necessárias à demonstração dos fatos em se assentam suas pretensões, embora de índole constitucional, não é, entretanto, absoluto. Ao contrário, como qualquer direito também está sujeito a limitações decorrentes da tutela que o ordenamento confere a outros valores e interesses igualmente dignos de proteção (GOMES FILHO, Antonio Magalhães. Direito à prova no processo penal. São Paulo: RT, 1997. p. 91).
} 
audiência sem a presença física do acusado, com a tomada de seus depoimentos por videoconferência e, na impossibilidade disso, poderá ordenar sua retirada da sala de audiência.

O texto do artigo deixa muito clara a intenção legislativa de estabelecer, nessa situação, uma exceção e não uma regra ${ }^{59}$. Com isso, deve o magistrado verificar com diligência se de fato a testemunha tem receio de prestar seu depoimento ou se há sério constrangimento. Inquestionável o confronto com o direito do acusado em acompanhar a produção da prova e discutível até a vulnerabilidade do direito de defesa, dado que advogado e réu não estarão juntos para eventuais reperguntas e na videoconferência não haverá nem mesmo contato direto com a testemunha. É irrefutável, pois, equilibrar o interesse público de proporcionar à vítima ou testemunha a tranquilidade necessária para prestar todos os esclarecimentos em busca da verdade com a atenuação, ainda que mínima, do direito de defesa, o que se autoriza tendo em vista o valor constitucional do jus puniendi pela busca da regularidade processual ${ }^{60}$.

Tornaghi anota que, por obra de glosadores, no procedimento inquisitorial, o juiz já tomava depoimentos sem a presença do réu, justamente para evitar a influência no estado de ânimo do depoente, tendo liberdade para os esclarecimentos em busca da verdade (testis non libere contra praesentem testificaret $)^{61}$.

O juiz deverá procurar contornar eventual prejuízo à defesa com outras medidas que podem ser úteis, como, v.g., a possibilidade de consulta do advogado com o réu antes de suas reperguntas. São medidas que, excepcionalmente, não prejudicarão o regular andamento do ato.

A presença do réu em audiência não é, portanto, direito essencial, núcleo impenetrável de sua amplitude de defesa, uma vez que é possível sua retirada da sala de audiência, bastando a adequada oportunidade de contrariar o depoimento da vítima e/ou da testemunha, ainda que sucessivamente à sua produção ${ }^{62}$.

\footnotetext{
${ }^{59}$ É muito comum se ver nos fóruns criminais a "automática" retirada do réu da sala de audiência, sem a preocupação, ao menos, de verificar se a testemunha realmente se sente ameaçada, tem receio de prestar seu depoimento com a presença física do acusado ou se haverá prejuízo para seu depoimento. Não é raro ver até mesmo depoimentos de policiais com a ausência do acusado pela prática indiscriminada desse expediente.

${ }^{60}$ SILVA, Eduardo Araújo. Crime organizado. São Paulo: Atlas, 2003. p. 132.

${ }^{61}$ TORNAGHI, Hélio. Curso de processo penal, p. 429.

${ }^{62}$ SILVA, Eduardo Araújo, op. cit., p. 133.
} 
Essa possibilidade também se verifica no direito estrangeiro.

No direito italiano, na disciplina dos programas de proteção à testemunha, são admitidas as medidas de "declarações a distância" dos arrependidos que colaboram com a justiça, desde que se trate de criminalidade organizada ${ }^{63}$.

Na Alemanha, desde 1998, a lei sobre "tutela de testemunhas" também fez referência ao depoimento a distância ou mediante videoconferência, mas estabeleceu a medida para os depoimentos de menores, vítimas, pessoas idosas com saúde precária ou doentes e as testemunhas ou corréus que colaboram com a justiça, em vista da possibilidade de exposição a intimidações ou ameaças ${ }^{64}$.

Nos Estados Unidos, a retirada do acusado do local onde se prestam depoimentos dependerá da possibilidade dele em acompanhar por sistema de vídeo e televisão ${ }^{65}$.

Por razões óbvias, entretanto, o acusado poderá ser retirado da sala de audiência se houver influência no "ânimo" ou causar humilhação, temor, ou sério constrangimento da testemunha (art. 217, CPP).

Conforme salientado no intróito deste trabalho, o aumento da criminalidade é estampado na imprensa como um "fenômeno terrificante",66, com o objetivo claro de "venda" da notícia, mas que estabelece um efeito secundário deletério, qual seja, a angústia popular decorrente do sentimento de medo, da necessidade de segurança e do inevitável receio de envolvimento, ainda que seja como simples testemunha de um fato criminoso.

É verdade que a vingança contra testemunhas não é tão comum, mas a escalada do crime cada vez mais aumenta a agressividade e a violência, notadamente nas comunidades carentes, onde se pratica a maioria dos crimes contra a pessoa.

\footnotetext{
${ }^{63}$ Eduardo Silva explica que o juiz deverá verificar se a coligação audiovisual assegura a visibilidade entre todas as pessoas que participam do ato processual, bem como se um auxiliar judicial está presente no local onde a testemunha ou colaborador prestará seu depoimento. Se a pessoa arguida tiver direito de ser assistida por seu defensor, será assegurada sua presença ou de seus assistentes, tanto no local onde se encontra, como naquele onde o ato processual se desenvolve perante o juiz (art. 146-bis, n. 3) (SILVA, Eduardo de Araújo. Crime organizado, p. 133).

${ }^{64}$ Ibidem, p. 134.

${ }^{65}$ Vejam-se observações deste trabalho no Capítulo 8, no item que trata dos programas de proteção no direito estrangeiro.

${ }^{66}$ BECK, Francis Rafael. Perspectivas de controle ao crime organizado e crítica à flexibilização das garantias, p. 93.
} 
Conclui-se que, estando presentes os requisitos legais, é viável a retirada do acusado do ambiente da audiência, garantindo à testemunha total segurança para declarar seus conhecimentos sobre os fatos.

Descreve o artigo 217 do Código de Processo Penal, com redação dada pela Lei no 11.690/08:

\begin{abstract}
"Se o juiz verificar que a presença do réu poderá causar humilhação, temor, ou sério constrangimento à testemunha ou ao ofendido, de modo que prejudique a verdade do depoimento, fará a inquirição por videoconferência e, somente na impossibilidade dessa forma, determinará a retirada do réu, prosseguindo na inquirição, com a presença do seu defensor.

Parágrafo único - A adoção de qualquer das medidas previstas no 'caput' deste artigo deverá constar do termo, assim como os motivos que o determinaram."
\end{abstract}

A redação antiga do dispositivo pré-citado não se diferenciava na substância. Foi, diga-se, atualizado dada a possibilidade da realização de audiência por videoconferência ${ }^{67}$.

Duas alterações chamam a atenção: a primeira, a regra de impor videoconferência e somente na impossibilidade ser simplesmente retirado o réu da sala de audiência e, a segunda, a inclusão do ofendido, interessado cuja figura não constava da redação anterior.

No tocante à videoconferência, a questão ainda é polêmica. O Supremo Tribunal Federal (STF) já impôs seu entendimento no sentido de que essa forma ofende as cláusulas do justo processo da lei (due process of law), limitando a ampla defesa, assim compreendidas a autodefesa e a defesa técnica ${ }^{68}$.

\footnotetext{
${ }^{67}$ Descrevia o artigo 217: "Se o juiz verificar que a presença do réu, pela sua atitude, poderá influir no ânimo da testemunha, de modo que prejudique a verdade do depoimento, fará retirá-lo, prosseguindo na inquirição, com a presença do seu defensor. Neste caso deverão constar do termo a ocorrência e os motivos que a determinaram.".

${ }^{68}$ Ementa Oficial: “Ação penal. Ato processual. Interrogatório. Realização mediante videoconferência. Inadmissibilidade. Forma singular não prevista no ordenamento jurídico. Ofensa a cláusulas do justo processo da lei (due process of law). Limitação ao exercício da ampla defesa, compreendidas a autodefesa e a defesa técnica. Insulto às regras ordinárias do local de realização dos atos processuais penais e às garantias constitucionais do réu preso, apenas instado a comparecer à sala da cadeia pública. Nulidade processual caracterizada. HC concedido para renovação do processo desde o interrogatório, inclusive. Inteligência dos arts. $5^{\circ}$, LIV, LV, LVII, XXXVII e LIII, da CF, e 792, caput e $\S 2^{\circ}, 403,2^{\underline{a}}$ parte, 185, caput e $\S 2^{-}$, 192, $\S$ único, 193, 188, todos do CPP. Enquanto modalidade de ato processual não prevista no ordenamento jurídico vigente, é absolutamente nulo o interrogatório penal realizado mediante videoconferência, sobretudo quando
} 
$\mathrm{Na}$ mesma esteira vieram outros julgados ${ }^{69}$, todos considerando inconstitucional a Lei $\mathrm{n}^{\mathrm{o}}$ 11.819/05 do Estado de São Paulo, por suplantar a legislação federal pertinente ${ }^{70}$.

Ora, a falta de determinação legal para o ato foi superada com a Lei no 11.900 , de 8 de janeiro de 2009, que especifica: "O interrogatório do réu preso será realizado, em sala própria, no estabelecimento em que estiver recolhido, desde que estejam garantidas a segurança do juiz, do membro do Ministério Público e dos auxiliares bem como a presença do defensor e a publicidade do ato.”. Nos parágrafos que seguem, existe especificação de, nos casos excepcionais, a realização do interrogatório ocorrer por videoconferência ou outro recurso tecnológico de transmissão de sons e imagens.

No que alude à audiência para a oitiva das testemunhas, o artigo 217 do Código de Processo Penal, com redação dada pela Lei $n^{\underline{0}} 11.690 / 08$, também possibilita o uso da videoconferência.

O STF ainda não se pronunciou a respeito dessa questão, restando aguardar decisão que elucide o assunto.

De qualquer forma, este trabalho não tem como linha de pesquisa a videoconferência; portanto, estabeleça-se a hipótese de sua não realização, mormente porque essa é a questão colocada da presença física do réu em audiência.

A providência, então, de retirada do réu, que excepciona o direito da defesa pelo devido processo legal, não é regra adotada somente nos tribunais pátrios. O Conselho da União Europeia, desde 1995, já fazia previsão de audiências a distância com o objetivo de assegurar a proteção de testemunhas. ${ }^{71}$

tal forma é determinada sem motivação alguma, nem citação do réu." (Habeas Corpus nº 88.914-0 São Paulo, Rel. Min. Cezar Peluso - Segunda Turma, j. 14 de agosto de 2007 - DJE no ${ }^{\text {o }}$ 117, divulgação 04.10.07, p.

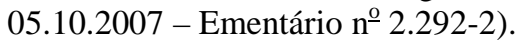

${ }^{69}$ HC90.900-SP, Rel. Min. Menezes Direito, j. 19.12.2008 e HC91.859-SP, Rel. Min. Carlos Britto, j. 04.11.2008. In: http://www.stf.jus.br/portal/jurisprudencia/listarJurisprudencia.asp?s1=videoconferencia \&base $=$ baseAcordaos. Acesso em: 3 nov. 2009.

${ }^{70}$ Acrescenta o Ministro Cezar Peluso em seu voto: Não existe, em nosso ordenamento jurídico, previsão legal para realização de interrogatório por videoconferência. E, suposto a houvesse, a decisão de fazê-lo não poderia deixar de ser suficiente motivada, com demonstração plena da sua excepcional necessidade no caso concreto (Habeas Corpus n⿳0 88.914-0 São Paulo, Rel. Min. Cezar Peluso).

${ }^{71}$ SILVA, Eduardo Araújo. Crime organizado, p. 131. 
No tocante à figura do ofendido, ainda que a antiga redação do artigo 217 do Código de Processo Penal não previsse a possibilidade, era pacífico o entendimento de que se aplicava também a ele a disposição por analogia ${ }^{72}$.

Resta dizer, por fim, sobre os casos simples de autodefesa ${ }^{73}$.

Para a autodefesa, um único ponto deve ser abordado, qual seja, o da omissão do nome da testemunha, pois enquanto o réu seja privado de ver ou ouvir o depoimento, poderia ele ser privado de saber quem o acusa?

Essa questão será abordada no Capítulo 8, que trata da Lei $\mathrm{n}^{0}$ 9.807/99, sobre as medidas protetivas - direito de preservação da identidade, imagem e dados pessoais.

72 TOURINHO FILHO, Fernando da Costa. Código de processo penal comentado. 10. ed. São Paulo: Saraiva, 2007. v. 1, notas ao artigo 217.

73 Autodefesa é aquela exercida pelo próprio réu em alguns momentos do processo, como o interrogatório, exemplo clássico de autodefesa (BRUNO NETO, Mario Augusto. O direito em debate: breves considerações acerca do Provimento n. 32/00. Boletim Ibccrim, v. 13, n. 152). 


\section{AS INOVAÇÕES DA LEI № ${ }^{\mathbf{0}} \mathbf{1 1 . 6 9 0 / 0 8}$}

A Lei n⿳0 11.690, de 9 de junho de 2008, alterou o Código de Processo Penal no que tange à prova. São três pontos principais:

- a disciplina geral das provas, tratando-se, entre outros, das provas ilícitas, inclusive por derivação;

- o procedimento da prova pericial, com intuito de agilizá-lo, de um lado, e de, assegurar o adequado contraditório e acompanhamento das provas periciais pelas partes, de outro; e

- o procedimento de colheita de prova testemunhal, com a finalidade de agilizar a sua produção e assegurar maior fidelidade aos depoimentos ${ }^{74}$.

A este trabalho interessa tão somente $\mathrm{o}$ procedimento referente à prova testemunhal, assim também entendida a oitiva do ofendido, eis que seu escopo é o estudo das medidas de proteção das vítimas e testemunhas diante de seus relatos no processo penal.

O artigo 201 do Código de Processo Penal foi alterado para incluir determinações referentes à vítima, notadamente sobre a sua proteção. Descreve a nova legislação três procedimentos em relação à vítima:

- comunicação de atos;

- atendimento específico antes da audiência; e

- medidas de proteção.

O ofendido tinha posição de simples "testemunha" no processo e assim era chamado para prestar seu depoimento e esclarecer os fatos e trazer ao conhecimento do juiz os acontecimentos relevantes para o julgamento da causa. Com o decorrer do tempo,

\footnotetext{
${ }^{74}$ MENDONÇA, Andrey Borges de. Nova reforma do Código de processo penal. São Paulo: Método, 2008. p. 153.
} 
todavia, passou-se a dar maior atenção àquele que foi o maior prejudicado com a ação criminosa.

O direito trouxe, inicialmente, relevância à sua vontade na medida em que aumentou os casos de ação penal pública condicionada à representação da vítima, v.g., lesão culposa em acidente de trânsito prevista na Lei $n^{0}$ 9.503/97 e lesão corporal leve vaticinada no artigo 88 da Lei no 9.099/95.

Além disso, nos crimes de menor potencial ofensivo (Lei nº 9.099/95), passou a haver possibilidade de composição dos danos civis (art. 75 da Lei em comento), o que repara com justiça o ato praticado contra o ofendido.

Agora, com a Lei n ${ }^{0}$ 11.690/08, também será necessária a comunicação ao ofendido de todos os atos processuais que se refiram "ao ingresso e à saída do acusado da prisão, à designação de data para audiência e à sentença e respectivos acórdãos que a mantenham ou modifiquem" (art. 155, $\left.\S 2^{\circ}, \mathrm{CPP}\right)$. Tais comunicações deverão ser efetuadas pessoalmente ou em seu endereço, admitindo-se, por opção da vítima, a comunicação por e-mail.

Quando da audiência, prevê o artigo a colocação da vítima em local próprio, ou seja, longe do acusado, sua família ou outras testemunhas.

Por fim, a novel legislação fez a previsão de medidas, as quais serão estudadas com mais profundidade neste trabalho. Descrevem os $\S \S 5^{\circ}$ e $6^{\circ}$ do art. 201:

\footnotetext{
“§ 5ำ - Se o juiz entender necessário, poderá encaminhar o ofendido para atendimento multidisciplinar, especialmente nas áreas psicossocial, de assistência jurídica e de saúde, a expensas do ofensor ou do Estado.

$\S 6^{0}-\mathrm{O}$ juiz tomará as providências necessárias à preservação da intimidade, vida privada, honra e imagem do ofendido, podendo, inclusive, determinar o segredo de justiça em relação aos dados, depoimentos e outras informações constantes dos autos a seu respeito para evitar sua exposição aos meios de comunicação."
}

Houve alteração também relativa ao procedimento de inquirição das testemunhas, introduzindo a nova legislação o sistema de inquirição direta (cross-examination), com base no direito norte-americano, pelo qual as partes efetuam as perguntas diretamente à testemunha, mantendo o magistrado uma posição diferenciada nesse momento processual 
daquela que exercia antes, mas não menos importante, dado que deverá efetuar fiscalização sobre a inquirição, em particular com o indeferimento de perguntas que possam induzir respostas, que não tiverem relação com a causa ou que sejam tão somente repetições injustificadas ${ }^{75}$.

Para efeito de complementação deste capítulo, reitera-se, conforme salientado neste trabalho, que também houve alteração do artigo 217, o qual já possibilitava a retirada do acusado da sala de audiência se a sua presença pudesse influenciar no "ânimo" da testemunha. A descrição do artigo ficou mais completa, pois não se fala em simples ânimo, mas em humilhação, temor ou sério constrangimento.

A retirada do acusado da sala também não é a solução buscada, pois o artigo impõe que o depoimento seja efetuado por videoconferência e somente na impossibilidade do emprego dessa forma é que o acusado será retirado do mesmo ambiente em que a testemunha prestará seu depoimento ${ }^{76}$.

\footnotetext{
${ }^{75}$ MENDONÇA, Andrey Borges de. Nova reforma do Código de processo penal, p. 195.
}

${ }^{76}$ Nesse sentido, a recente Lei n⿳⺈ 11.900 , de 8 de janeiro de 2008. 


\title{
5. HISTÓRICO DA CRIMINALIDADE E DA AGRESSIVIDADE CONTRA VÍTIMAS E TESTEMUNHAS
}

\begin{abstract}
"Estava no bar com amigos quando eles entraram armados. Mostrei minha carteira de trabalho, mas atiraram assim mesmo. Levei cinco tiros. Nasci de novo, mas não sei se valeu a pena. Talvez quisesse ter morrido. Não estaria passando por tanto sofrimento e medo. Proteção mesmo, só tive de São Jorge, de Deus e da comunidade de Vigário Geral. O governo nunca me protegeu. Nos dois primeiros depoimentos fui de ônibus com minha mulher. Por causa das ameaças, quisemos ir para Niterói, mas um dos policiais da escolta estava indiciado. Hoje é a própria comunidade que nos protege, inclusive alguns traficantes. Continuo trabalhando, mas deixei de desfilar na Acadêmicos de Vigário Geral e de ver o Flamengo jogar. Só me submeto a isso por causa de meus amigos mortos". Jadir

"Já faz sete meses que corro como um fugitivo. Vendi tudo o que tinha e mandei minha mulher e meus filhos para a casa da família. Em Manaus, invadiram o quarto do hotel que eu tinha ocupado na véspera e mataram o hóspede. Fui para um seringai [sic] em Tarauacá (divisa entre o Acre e o Amazonas), mas me encontraram lá. Fiquei três dias na mata. Fui para casa de parentes em São Paulo. Comecei a receber telefonemas suspeitos. Fugi para Santarém. Lá comecei a ser seguido pela própria polícia. Capotei duas vezes o carro. Aqui, estou clandestino. Não tenho sequer um passaporte para poder procurar um trabalho decente. Só tive oferta para traficar. Isso não faço. Gravei uma fita contando tudo. Ofereceram $\mathrm{R} \$ 30$ mil pela minha cabeça. O último por quem ofereceram recompensa foi morto no Piauí. O matador levou R\$50 mil. Só durmo com tranqüilizantes. Minha família está passando necessidades. Tem dia que acordo pensando em fazer alguma besteira. Não vejo sentido em viver assim. Tenho 29 anos e meu maior crime foi ter visto o que não devia”. F.P.
\end{abstract}

(Relatos de testemunhas perseguidas, Revista Época, n. 14, ago. 1998)

O homem é um ser que vive em sociedade. Não tem a natureza solitária como alguns animais conhecidos. Desde os primórdios e, decerto, desde a primeira comunidade formada, as relações humanas já apresentavam conflitos $^{77}$ e violação de seus direitos, e esse é o maior desafio do direito, ou seja, assegurar aos seres humanos o respeito a seus direitos fundamentais ${ }^{78}$.

\footnotetext{
${ }^{77}$ Escreve Lipinski: "Desde os primórdios dos tempos o homem foi obrigado a conviver com fatos delituosos nas suas mais diversas formas. Na sociedade sempre foi cultuado o poder, o mais forte subjugando o mais fraco, um país dominando o outro, e uma determinada civilização impondo a sua cultura a um povo dominado. Estas atividades estavam sempre relacionadas ao comércio, marco das expansões territoriais de diversos países e o ciclo da colonização. Iniciara-se com o comércio de especiarias e escravos nos primeiros tempos da Era Cristã, depois as guerras com objetivo de conquista e para a imposição do cristianismo" (LIPINSKI, Antonio Carlos. Crime organizado e a prova penal. 4. tiragem. Curitiba: Juruá, 2006. v. I, p. 15). ${ }^{78}$ LOURENÇO, Messias José. Crime organizado e lei de proteção de testemunhas. Lex - Jurisprudência do Superior Tribunal de Justiça e Tribunais Regionais Federais, v. 16, n. 181, p. 9/22, set. 2004, p. 9.
} 
A violação de direitos subjetivos veio acompanhada da violência e agressividade e a tendência do homem viver em grupos propiciou a formação de associações criminosas, que apresenta íntima relação com as transformações sociais. Não se pode afirmar, portanto, que a existência de um grupo de pessoas unidas para as atividades criminosas seja considerado um fenômeno moderno, muito embora a globalização e a evolução tecnológica tenham contribuído para o desenvolvimento das máfias contemporâneas ${ }^{79}$. A verdade é que a participação de duas ou mais pessoas em atividades ilícitas é tão antiga quanto a sociedade, e a organização para essa prática também sempre existiu. Ocorre, entretanto, que na sociedade moderna a união de pessoas ganhou alto grau de sofisticação e $\operatorname{organização~}^{80}$.

Do ponto de vista sociológico, as atividades de uma tribo que se armava e treinava para dominação e saques de uma tribo vizinha há duzentos anos são analogicamente as mesmas do grupo armado que efetua roubo de cargas com condutas ordenadas e combinadas de forma objetiva ${ }^{81}$. Por óbvio que as formas foram aprimoradas, mas os objetivos são exatamente iguais.

Em percuciente pesquisa, Eduardo Araújo da Silva apresenta um histórico da formação desses grupos criminosos nos mais variados países e conclui para destacar:

$$
\begin{aligned}
& \text { “(...) alguns traços comuns entre as diversas origens das organizações } \\
& \text { criminosas nos diferentes países: a maioria teve como nascedouro } \\
& \text { movimentos populares, o que facilitou sobremaneira sua aceitação na } \\
& \text { comunidade local, assim como o recrutamento de voluntários para o } \\
& \text { exercício de suas posteriores atividades ilícitas; muitas delas passaram a } \\
& \text { atuar no vácuo de algumas proibições estatais (exploração da } \\
& \text { prostituição, jogos de azar, venda de entorpecentes e de armas } \\
& \text { sofisticadas), contaram com a conivência de agentes do Estado para o } \\
& \text { desenvolvimento de suas atividades ilícitas; e impuseram sua lei pelo } \\
& \text { emprego da ameaça e violência, voltada sobretudo para delatores e } \\
& \text { integrantes de grupos concorrentes. Tais pontos semelhantes na verdade } \\
& \text { constituem algumas das principais características do fenômeno (......" }
\end{aligned}
$$

\footnotetext{
79 BECK, Francis Rafael. Perspectivas de controle ao crime organizado e crítica à flexibilização das garantias, p. 57.

${ }^{80}$ Ibidem, p. 56.

${ }^{81}$ LIPINSKI, Antonio Carlos. Crime organizado e a prova penal, p. 15.

${ }^{82}$ SILVA, Eduardo Araújo. Crime organizado, p. 27.
} 
As primeiras organizações formadas para a prática de delitos apareceram em 1644, com as Tríades Chinesas ${ }^{83}$ e logo em seguida com a máfia japonesa denominada Yakusa do século XVIII ${ }^{84}$. Por fim, culminou esse processo com as máfias italianas no ano de $1812^{85}$, mas somente no século XX passaram à prática de crimes. Surgiram as máfias específicas na Itália, como a Cosa Nostra da Sicília, a Camorra da região da Campânia, a Sacra Corona Unita, da região da Apúlia, na costa do Mar Adriático, e a N'Dranghetta ${ }^{86}$. O modelo mafioso se desenvolveu com as atividades características e marcadamente criminosas de tráfico de drogas, exploração do lenocínio e de jogos de azar, fraudes em concorrências públicas, venda de proteção, sequestro de pessoas, usura, dentre outras, o que não lhes impedia algumas atividades lícitas como aplicação em bolsa de valores, empreendimentos imobiliários e turismo ${ }^{87}$.

No Oriente Médio também apareceram organizações criminosas, mas com finalidades terroristas, como é o caso do Hezbollah, que significa "partido de Deus". Formado na década de 1980, no Líbano, o Hezbollah, de natureza islâmica, teve sempre por objetivo lutar contra a ocupação israelense. Outra organização é o Hamas, símbolo da resistência islâmica palestina de 1987, responsável por vários atentados contra Israel, dentre outros grupos terroristas como o Grupo Armado Islâmico (GIA) de 1992, na Argélia, realizando massacres civis e atentados contra estrangeiros; a Gama'al-Islamiyya, grupo islâmico egípcio formado em 1970; a Al-Qaeda, de Osama Bin Laden no Afeganistão; Abu Sayyaf e Frente Moro de Libertação Nacional, grupo do sul das Filipinas; o PKK - Partido dos Trabalhadores do Curdistão, na Turquia; os Tigres da Libertação do Eelam Tâmil, contra o governo do Sri Lanka ${ }^{88}$.

\footnotetext{
${ }^{83}$ Eduardo Araújo da Silva salienta que se tratou de um movimento popular formado com o objetivo de expulsar os invasores do Império Ming: "Com a declaração de Hong Kong como colônia britânica em 1842, seus membros migraram para essa colônia e posteriormente para Taiwan, onde não encontraram dificuldades para incentivar os camponeses para o cultivo da papoula e exploração do ópio" (SILVA, Eduardo Araújo. Crime organizado, p. 20).

${ }^{84}$ A Yakusa desenvolveu-se nas sombras do Estado explorando atividades ilícitas (cassinos, prostíbulos, turismo pornográfico, tráfico de mulheres, drogas e armas, lavagem de dinheiro e usura). Eduardo Araújo da Silva também salienta que houve exploração de negócios lícitos como casas noturnas, teatros, cinema e publicidade e eventos esportivos. "Com o desenvolvimento industrial do Japão durante o século XX, seus membros também passaram a dedicar-se à prática das chamadas 'chantagens corporativas', pela atuação dos sokaiya (chantagistas profissionais) que, após adquirirem ações de empresas, exigem lucros exorbitantes, sob pena de revelarem os segredos aos concorrentes" (SILVA, Eduardo Araújo, op. cit., loc. cit.).

${ }^{85}$ As máfias italianas surgiram como movimento de resistência contra o rei de Nápoles, que em 1812 baixou decreto responsável por abalar a secular estrutura agrária da Sicília, reduzindo os privilégios feudais e limitando os poderes dos príncipes, que contrataram uomini d'onore para proteger as investidas contra a região, os quais passaram a constituir associações secretas denominadas máfias (ibidem, loc. cit.).

${ }^{86}$ Ibidem, p. 21.

${ }^{87}$ LIPINSKI, Antonio Carlos. Crime organizado e a prova penal, p. 17.

${ }^{88}$ SILVA, Eduardo Araújo da, op. cit., p. 22.
} 
Na Rússia, as organizações criminosas passaram a existir na última década do século XIX, ainda na época czarista, nos campos da Sibéria. Os crimes mais comuns eram extorsão, tráfico de mulheres, corrupção, desvio de dinheiro público e roubo. Segundo Eduardo Silva, na “implantação da perestroika, essas organizações empunharam a bandeira da defesa do Estado contra a agressão do capitalismo ocidental, transformando-se para muitos num verdadeiro refúgio da dignidade nacional" $" 89$.

Nos Estados Unidos, as organizações criminosas começam a se formar após a década de 1920, particularmente em razão da lei seca, com o contrabando de bebida, corrupção de autoridades e várias chantagens. As famiglias se associaram a alguns produtores de bebidas alcoólicas e dominaram, com o tempo, toda a cadeia produtiva ${ }^{90}$. As lutas violentas com muitas mortes ${ }^{91}$ ocorreram pela disputa entre as várias gangs pelos territórios ocupados do contrabando. Com isso, os grupos passaram a patrocinar também a prostituição e o jogo. Havia as lavanderias, que faziam a lavagem de dinheiro, o que mostra, na história, a vinculação do crime organizado com toda espécie de ilícito e que a forma de acabar com essa prática é a descoberta da origem do dinheiro ${ }^{92}$.

\begin{abstract}
"Após o desenvolvimento econômico norte-americano, verificado a partir da Segunda Guerra Mundial, mais nítida ficou a influência dessas atividades no poder político e econômico. A migração de algumas famílias da Cosa Nostra para o território norte-americano, sobretudo na década de 60 (século passado), ensejou a criação da Máfia ítaloamericana, passando esse grupo a atuar em diversas frentes, inclusive no tráfico de entorpecentes." 93
\end{abstract}

$\mathrm{Na}$ América do Sul, basicamente, as organizações criminosas focam suas ações no cultivo e exploração da coca, bem como sua transformação na pasta base para o refinamento da cocaína.

\footnotetext{
${ }^{89}$ SILVA, Eduardo Araújo. Crime organizado, p. 23.

${ }^{90}$ LIPINSKI, Antonio Carlos. Crime organizado e a prova penal, p. 16.

91 O marco foi a guerra havida entre as famílias Matranga e Provenzano em New Orleans, de 1890 (LOURENÇO, Messias José. Crime organizado e lei de proteção de testemunhas. Lex - Jurisprudência do Superior Tribunal de Justiça e Tribunais Regionais Federais, v. 16, n. 181, p. 9/22, p. 9).

92 LIPINSKI, Antonio Carlos, op. cit., loc. cit.

${ }^{93}$ SILVA, Eduardo Araújo da, op. cit., p. 24.
} 
$\mathrm{Na}$ Argentina, as ações de organizações criminosas estão restritas ao narcotráfico, ao tráfico de armas e de pessoas, à corrupção e ao contrabando. Não há notícia de organizações mafiosas, apenas menções a grupos estrangeiros, em especial italianos e israelitas - Mão Negra, Chico Grande, Zwi Migdal -, os quais se estabeleceram em determinadas regiões (Rosário). Atualmente, há notícia sobre atuação das Tríades Chinesas, que respondem por dois terços do tráfico de heroína no mundo e, segundo estimativas da Polícia Nacional do Paraguai, movimentam cerca de US\$ 9 milhões por mês na Tríplice Fronteira. Na Argentina é registrado também envolvimento dessa organização com o tráfico de mulheres.

A Argentina é signatária de diversos tratados internacionais de combate ao terrorismo e seu financiamento, além de integrar organizações com a mesma finalidade ${ }^{94}$.

Destacam-se apenas dois atentados terroristas: em 1992, contra a Embaixada de Israel, e em 1994, contra a Associação Mútua Israelita. A Argentina - a Tríplice Fronteira como um todo - também é destacada como refúgio ou sede de núcleos de organizações terroristas internacionais.

Nos convênios internacionais e nos trabalhos desenvolvidos pelos órgãos, percebese uma preocupação muito grande com o financiamento das organizações terroristas, mas não há registros de casos, na Argentina, de congelamento, embargos ou confiscos de bens cuja finalidade seria o financiamento de atividades terroristas.

No plano interno há uma definição legal de atos de terrorismo (Lei n⿳ํㅡㄹ 25.241/2000), muito embora não exista definição legal do terrorismo como delito autônomo ${ }^{95}$.

No Brasil, as primeiras organizações criminosas foram identificadas com o cangaço $^{96}$ no final do século XIX em razão do coronelismo que vigia na época e da

\footnotetext{
${ }^{94}$ Em resumo, as organizações criminosas na Argentina são: Grupo de Acción Financiera (Gafi) e Grupo de Acción Financiera de Sudamérica contra el Lavado de Activos (Gafisud), Tríplice Frontera, entre outras. No âmbito interno, há as seguintes organizações: Representación Especial para Asuntos de Terrorismo y Otros Delitos Conexos (Retod); Plan Nacional de Prevención del Delito - vinculada ao Ministério da Justiça; e Unidad de Información Financiera (UIF). Comunicam-se com o Comitê Contra o Terrorismo (CCT) da Organização das Nações Unidas (ONU) e o Comitê Interamericano contra o Terrorismo (CICTE) da Organização dos Estados Americanos (OEA).

95 “(...) se consideran hechos de terrorismo las acciones delictivas cometidas por integrantes de asociaciones ilícitas u organizaciones constituidas con el fin de causar alarma o temor, y que se realicen empleando sustancias explosivas, inflamables, armas o en general elementos de elevado poder ofensivo, siempre que sean idóneos para poner en peligro la vida o integridad de un número indeterminado de personas" (art. $1^{\underline{0}}$ ).

96 A palavra se origina de canga, o conjunto de arreios que amarram o boi ao carro. Segundo Olivieri, é provável que esse nome tenha surgido porque os bandoleiros usavam as espingardas a tiracolo ou com as
} 
necessidade da atividade violenta de jagunços e capangas de grandes fazendeiros. Essa violência evoluiu para saques de vilas e pequenas cidades, com a extorsão de dinheiro mediante sequestro de pessoas e ameaças ${ }^{97}$. No século XX surgiu o "jogo do bicho", primeira prática delituosa organizada após o cangaço ${ }^{98}$.

A partir daí, a organização para o tráfico nos morros e favelas e para a atuação no interior dos presídios foi rápida, com o aparecimento de movimentos como "Comando Vermelho", "Terceiro Comando" e "Falange Vermelha"99 no Rio de Janeiro e Primeiro Comando da Capital (PCC) em São Paulo. Os primeiros movimentos desses grupos ocorreram em 1970 no Rio de Janeiro, notadamente nas favelas, que praticavam tráfico de entorpecentes e assaltos a bancos ${ }^{100}$.

O fortalecimento da proteção nos bancos com a instalação de novos mecanismos porta giratória detectora de metais, agentes de segurança fardados ou não, alarmes de ligação direta com a polícia, cofres com segredo de tempo e outros - trouxe dificuldades ao empreendimento, o que resultou em vertiginosa queda dos números atinentes a esse crime. Com isso, houve o incremento das práticas de roubos de $\operatorname{cargas}^{101}$.

Não se pode olvidar da organização silenciosa (não violenta) como a biopirataria comércio irregular de madeiras nobres, por exemplo -, que já alcança mais de um bilhão de dólares, superada apenas pelo tráfico de entorpecentes e de armas.

Em verdade, os "profissionais do crime" estão sempre inovando ou pensando em formas de fugirem da responsabilização penal. Além disso, desenvolvem estratégias empresariais dignas de grandes empreendimentos com a finalidade da busca do lucro. Como essas atividades têm caráter empresarial, os indivíduos que delas participam devem ser chamados de "profissionais do crime" ou "profissionais do crime organizado".

correias no peito, lembrando a canga do boi (OLIVIERI, Antonio Carlos. O cangaço. 2. ed. São Paulo: Ática, 1997. p. 9. In: SILVA, Eduardo Araújo da. Crime organizado, p. 25.

${ }^{97}$ SILVA, Eduardo Araújo da, op. cit., loc. cit.

${ }^{98}$ Tratava-se de sorteio de prêmios a apostadores mediante recolhimento de apostas iniciada no limiar do século XX. A origem dessa contravenção penal é atribuída ao Barão de Drumond, que teria criado o inocente jogo de azar para arrecadar dinheiro com a finalidade de salvar os animais do Jardim Zoológico do Estado do Rio de Janeiro. A ideia foi posteriormente popularizada e patrocinada por grupos organizados, que passaram a monopolizar o jogo, mediante corrupção de policiais e políticos. Na década de 1980 , os praticantes dessa contravenção movimentavam cerca de US\$ 500.000 por dia com apostas, sendo $4 \%$ a $10 \%$ desse montante destinado aos banqueiros (ibidem, loc. cit.).

${ }^{99}$ Quadrilhas de roubo a bancos formadas no Presídio de Illha Grande.

${ }^{100}$ LIPINSKI, Antonio Carlos. Crime organizado e a prova penal, p. 24.

${ }^{101}$ O mapa do Brasil apresentou "pontos negros" de alta incidência de roubos de caminhões e cargas, que são negociadas muito rápido, com o ingresso, na organização, de agentes públicos (ibidem, p. 23). 
A ausência de política de proteção e de prevenção ao crime possibilitou o desenvolvimento de organismos criminosos interligados em todos os Estados da Federação, contaminando todos os níveis da sociedade e até altos escalões do Poder Público.

O Brasil atual apresenta todos os fatores favoráveis à explosão da criminalidade, como fome, desemprego, diferenças sociais, racismo e preconceito, defasagem nas vagas de escola e completa despreocupação com educação e cultura ${ }^{102}$. Esse cenário acarreta inevitável crescimento da macrocriminalidade e torna núcleos habitacionais pobres verdadeiros guetos sem controle e inacessíveis ao Estado.

O uso da violência e intimidação é característica do crime organizado. Dizer que isso somente ocorreu na "fase clássica" da máfia, como do começo do século passado com as máfias americanas do tráfico de bebidas ou nos grupos armados terroristas, é desconhecer a situação atual do crime organizado no Brasil e no mundo, muito embora não seja necessário suceder tal intimidação para que fique caracterizada a ocorrência do crime organizado.

Sabe-se que é possível a diminuição dessa modalidade criminosa em decorrência do desenvolvimento do caráter empresarial e tecnológico da organização, mas isso somente até o momento em que a "empresa" do crime não se verificar ameaçada por delação ou pela possibilidade do depoimento comprometedor.

Como bem avaliou Francis Beck:

"Esta violência ou intimidação também pode ser enquadrada na utilização da chamada 'lei do silêncio', ou omertà, que guarda algumas semelhanças com o tradicional método criminoso de ameaçar com morte os possíveis delatores. Esta obrigação de manter sigilo acerca das atividades da organização tanto pode se dirigir aos seus membros (como é mais comum) quanto a terceiros sem nenhum vínculo aparente com a organização. Este último é o caso, por exemplo, dos moradores dos morros cariocas 'controlados' pelo tráfico de drogas"103.

\footnotetext{
${ }^{102}$ LIPINSKI, Antonio Carlos. Crime organizado e a prova penal, p. 24.

${ }^{103}$ BECK, Francis Rafael. Perspectivas de controle ao crime organizado e crítica à flexibilização das garantias, p. 88.
} 
Essa situação pôde ser constatada com clareza já na década de 1980, em razão de uma política de contenção das atividades das organizações criminosas no Brasil, mais a falta de aparelhamento da polícia. A legislação não foi suficiente para conter o avanço rápido do crime organizado, ramificado entre os estados da Federação. Já nessa época era comum a "queima de arquivo" com homicídios dos membros de quadrilhas presos ${ }^{104}$.

O uso da violência é absolutamente aceitável a esses grupos criminosos, na medida em que em determinadas circunstâncias essa é a única maneira de se alcançar seus objetivos. Claro que tudo é feito na forma de dissimulação, eis que a prática de homicídios e "queima de arquivo", notadamente de testemunhas, poderá causar "repulsa por parte da população fazendo nascer sentimento de revolta" ${ }^{105}$, o que não é interessante nem mesmo para a criminalidade.

Embora não exista definição legal para crime organizado, a doutrina estabelece suas principais características:

- colaboração de certo número de pessoas;

- tempo prolongado e indefinido;

- disciplina e controle internos;

- operação em âmbito internacional;

- violência e intimidação;

- estrutura comercial por meio de empresas legais;

- influência política;

- tecnologia de instrumentos.

Como já se verificou, a prova testemunhal é basilar para investigação do crime e sua persecução e, por razões óbvias, as testemunhas-chave se tornam alvos dos criminosos que buscam a impunidade.

Não é sem razão que cada dia mais testemunhas se mostram receosas de prestarem seus depoimentos na polícia ou em Juízo e, por consequência, o prejuízo para a instrução é certo. São raras as situações em que a testemunha aceita prestar seu depoimento na presença do acusado.

\footnotetext{
${ }^{104}$ LIPINSKI, Antonio Carlos. Crime organizado e a prova penal, p. 23.

${ }^{105}$ MENDRONI, Marcelo Batlouni. Crime organizado - aspectos gerais e mecanismos legais, p. 19.
} 
Além disso, era necessário mesmo estabelecer uma verdadeira proteção dessa testemunha, pois, afinal, ela está prestando um serviço de utilidade pública, mas com ônus somente a sua pessoa.

O relator do substitutivo que se tornou a Lei $\mathrm{n}^{\mathrm{o}}$ 9.807/99, Deputado Alberto Mourão, na oportunidade dos trabalhos legislativos, já levantava essa problemática ao ressaltar que tudo se deve ao "sentimento de impunidade" e que isso ocorria fundamentalmente pela falta de provas no processo penal. As testemunhas têm medo de colocar em risco não apenas suas vidas, mas as de sua família também ${ }^{106}$.

Luiz Flávio Gomes ressalta as práticas graves (chacinas, conflitos agrários, violência de policiais e corrupção) como "etiologia criminógena própria", virtualmente mais intimidantes ${ }^{107}$.

A respeito do assunto em comento, Pedro Roberto Decomain pondera:

“(...) em crime graves, pode surgir - e com freqüência surge - interesse da parte dos respectivos autores em intimidar testemunhas e vítimas, tentando, com isso, evitar que prestem os informes de que dispõem, o que assegurará ou facilitará a impunidade do delinqüente. Quem se presta à autoria de crimes graves não mede esforços, usualmente, para assegurar a impunidade. E o alvo desses ilícitos esforços frequentemente são as pessoas que, vitimadas ou não, podem esclarecer a autoria. Um fator adicional a colocar em risco o valor da prova testemunhal, e, até mesmo, em situações extremas, a própria vida da testemunha ou da vítima."108

\footnotetext{
${ }^{106}$ Entrevista publicada pela Câmara dos Deputados, Brasília: 2000.

${ }^{107}$ GOMES, Luiz Flávio. Lei de proteção a vítimas e testemunhas: primeiras considerações. Repertório IOB Jurisprudência, n. 18/99, 2ª quinzena de set. 1999, Caderno 3, p. 436.

${ }^{108}$ DECOMAIN, Pedro Roberto. Proteção a testemunhas: redução de pena para o acusado que colabora com a investigação criminal. Revista do Ministério Público/Ministério Público do Estado do Rio de Janeiro, n. 12, p. 144.
} 


\section{MECANISMOS DE COMBATE AO CRIME ORGANIZADO}

Na década de 1980, em função da ausência absoluta de uma legislação eficiente, houve início dos debates a respeito do crime organizado, em que se discutiram os vários mecanismos, como identificação criminal, delação premiada, interceptações telefônicas e possibilidade de quebra de sigilos bancário e fiscal.

Em 1995 surgiu a Lei $n^{0}$ 9.034/95, conhecida como a Lei de Combate ao Crime Organizado, mas, por óbvio, saliente-se que somente a promulgação de leis não seria mesmo suficiente ao combate a esse crime organizado ${ }^{109}$. A implementação de projetos de segurança e combate ao crime passa muito mais por orçamento público, boa vontade política e coragem para extrair dos poderes públicos qualquer influência do banditismo.

De qualquer forma, o debate em torno da política criminal deu origem ao Projeto 3.516/89, que já anotava correntes conceituais e definia organização criminosa como "aquela que, por suas características, demonstre a existência de estrutura criminal, operando de forma sistematizada, com atuação regional, nacional e/ou internacional”.

O Projeto não foi, no entanto, aprovado conforme instituído e a Lei $\mathrm{n}^{\mathrm{o}}$ 9.034/95 abandona todas as correntes doutrinárias, estabelecendo que "define e regula meios de prova e procedimentos investigatórios que versarem sobre crime resultante de ações de quadrilha ou bando".

Como se verifica, nem mesmo a definição sobre crime organizado foi mantida do Projeto em comento, causando uma lacuna jurídica e consequente prejuízo à aplicação de

\footnotetext{
109 Como bem escreveu Átila da Rold Roesler: "Todas as medidas que forem tomadas em termos de segurança pública só surtirão efeitos se acompanhadas de ações de alcance social. Em longo prazo, o investimento em políticas sociais trará mais resultados do que aquisições de viaturas e armamentos, criação de delegacias especializadas, promulgação de leis ineficazes, construção de novos presídios e discursos inflamados da lei e da ordem. Nesse sentido, Juarez Cirino dos Santos alerta que a resposta penal contra o chamado crime organizado é mais ou menos semelhante em toda parte: maior rigor repressivo, introdução de novas modalidades de prisões cautelares, instituição de 'prêmio' ao acusado colaborador, criação de programas de proteção de testemunhas... A experiência mostra que essa resposta penal se situa no plano simbólico, como satisfação retórica à opinião pública pela estigmatização oficial do crime organizado, mas tem sua utilidade: cumpre o papel de evitar discussões sobre o modelo político neoliberal dominante nas sociedades contemporâneas, ocultando responsabilidades do capital financeiro internacional, aliado às elites conservadoras dos países do Terceiro Mundo, na criação de condições adequadas à expansão da criminalidade em geral e, eventualmente, de organizações locais de tipo mafioso" (SANTOS, Juarez Cirino dos. Crime organizado. In: Direito penal e direito processual penal - uma visão garantista. Rio de Janeiro: Lumen Juris, 2001. p. 148, publicado em A falácia do combate ao crime organizado. In: http://jus2.uol.com.br/doutrina/texto.asp?id=5214, Jus Navigandi. Acesso em: 22 maio 2007).
} 
todos os institutos ali previstos, frutos do desenvolvimento das legislações processuais penais dos países mais desenvolvidos. Ora, a lei combate o crime organizado, mas nem sequer o define. É como uma caça a um fantasma, cuja feição, cor, tamanho e forma não se conhecem.

Surgem, assim, as discussões a respeito da efetiva aplicação - crimes de quadrilha ou bando ou só crime organizado -, mas como aplicar ao crime organizado se não há eficácia?

Nova disciplina aparece com a Lei $\mathrm{n}^{\mathrm{o}}$ 10.217/01; porém, houve avanço tímido no sentido de acrescentar à lei anterior que os procedimentos seriam estendidos a organizações ou associações criminosas de qualquer tipo. E continua a não definir organização criminosa.

Nos termos das leis promulgadas, portanto, são três conteúdos diversos:

- organização criminosa (não tipificada);

- associação criminosa (tipificada na lei de tóxicos e Lei $\mathrm{n}^{\mathrm{o}}$ 2.889/56 - associação para a prática de genocídio); e

- quadrilha ou bando.

Luiz Flávio Gomes entende que se trata de um conceito vago e, portanto, não possibilita eficácia aos dispositivos que fazem previsão legal a qualquer aplicação referente ao crime organizado ${ }^{110}$.

\footnotetext{
110 Descreve o autor: Não existe em nenhuma parte do nosso ordenamento jurídico a definição de organização criminosa. Cuida-se, portanto, de um conceito vago, totalmente aberto, absolutamente poroso. Considerando-se que (diferentemente do que ocorria antes) o legislador não ofereceu nem sequer a descrição típica mínima do fenômeno, só nos resta concluir que, nesse ponto, a lei (9.034/95) passou a ser letra morta. Organização criminosa, portanto, hoje, no ordenamento jurídico brasileiro, é uma alma (uma enunciação abstrata) em busca de um corpo (de um conteúdo normativo, que atenda o princípio da legalidade). Se as leis do crime organizado no Brasil (Lei 9.034/95 e Lei 10.217/01), que existem para definir o que se entende por organização criminosa, não nos explicaram o que é isso, não cabe outra conclusão: desde 12.04 .01 perderam eficácia todos os dispositivos legais fundados nesse conceito que ninguém sabe o que é. São eles: arts. $2^{\circ}$, inciso II (flagrante prorrogado), $4^{\circ}$ (organização da polícia judiciária), $5^{\circ}$ (identificação criminal), $6^{\circ}$ (delação premiada), $7^{\circ}$ (proibição de liberdade provisória) e $10^{\circ}$ (progressão de regime) da Lei 9.034/95, que só se aplicam para as (por ora, indecifráveis) "organizações criminosas". É caso de perda de eficácia (por não sabermos o que se entende por organização criminosa), não de revogação (perda de vigência). No dia em que o legislador revelar o conteúdo desse conceito vago, tais dispositivos legais voltarão a ter eficácia. Por ora continuam vigentes, mas não podem ser aplicados. (GOMES, Luiz Flávio. Crime organizado: que se entende por isso depois da Lei noำ12.217/01?, Jus Navigandi, 22 maio 2007).
} 
A Convenção das Nações Unidas contra o Crime Organizado Transnacional definiu Grupo criminoso organizado como:

“(...) grupo estruturado de três ou mais pessoas, existente há algum tempo
e atuando concertadamente com o propósito de cometer uma ou mais
infrações graves ou enunciadas na presente Convenção, com a intenção
de obter, direta ou indiretamente, um benefício econômico ou outro
benefício material". ${ }^{111}$

Segundo Eduardo Araújo da Silva, eventualmente será possível utilizar a definição de crime organizado do Tratado de Palermo, resultante da Convenção da Organização das Nações Unidas sobre a Delinquência Organizada Transnacional, realizada no período de 12 a 15 de novembro de 2000, que prevê como organização criminosa a reunião de mais de três pessoas (requisito estrutural), de forma estável (requisito temporal) e que vise à prática de crimes graves, assim considerados com pena igual ou superior a quatro anos, com intuito de lucro (requisito finalístico) ${ }^{112}$.

Também foram promulgadas outras leis específicas como mecanismos de controle ou de investigação do crime organizado: a Lei no 9.296/96 - que regulamenta a violabilidade das comunicações telefônicas; a Lei $\mathrm{n}^{0}$ 9.613/98 - que dispõe sobre o crime de lavagem de dinheiro e estabelece os tipos penais correspondentes, bem como as medidas assecuratórias; a Lei n. 9.807/99 - sobre a organização e manutenção de programas especiais de proteção às vítimas e testemunhas (objeto de estudo específico adiante, neste trabalho) e, por fim, a Lei Complementar $n^{-}$105/01 - sobre o sigilo das operações de instituições financeiras.

A Lei Complementar pré-citada faz previsão específica em seu Art. $1^{1}$ :

“(..)

$\S 4^{\underline{0}}$ - A quebra de sigilo poderá ser decretada, quando necessária para apuração de ocorrência de qualquer ilícito, em qualquer fase do inquérito ou do processo judicial, e especialmente nos seguintes crimes:

I - de terrorismo;

\footnotetext{
${ }^{111}$ Convenção adotada em Nova York, em 15 de novembro de 2000, e ratificada pelo Brasil com o Decreto no 5.015, de 12 de março de 2004.

${ }^{112}$ SILVA, Eduardo Araújo da. Crime organizado, p. 35.
} 
II - de tráfico ilícito de substâncias entorpecentes ou drogas afins;

III - de contrabando ou tráfico de armas, munições ou material destinado a sua produção;

IV - de extorsão mediante seqüestro;

$\mathrm{V}$ - contra o sistema financeiro nacional;

VI - contra a Administração Pública;

VII - contra a ordem tributária e a previdência social;

VIII - lavagem de dinheiro ou ocultação de bens, direitos e valores;

IX - praticado por organização criminosa."

Conclui-se, pois, que tudo isso faz emergir a necessidade de se buscarem alternativas para a eficiência do processo penal, com vistas - reiterando-se o que é propugnado ao longo deste trabalho - ao resultado prático positivo da persecução criminal, sem, no entanto, desviar-se das garantias constitucionais do devido processo legal. 


\section{O EQUILÍBRIO ENTRE A EFICIÊNCIA E O GARANTISMO}

Conforme salientado neste trabalho, a vontade de alcançar a solenidade da verdade - e esse deve ser o objetivo do operador do direito - leva este pesquisador a encarar o instituto da prova testemunhal e, por consequência, da proteção de vítimas e testemunhas como um dos caminhos necessários para o cumprimento da lei penal ou, bem assim, como mecanismo de efetividade do processo penal.

A efetividade do processo é a busca principal do direito processual moderno. Em análise perfunctória da evolução legislativa se verifica que a tentativa é, com frequência, de simplificação com escopo de alcançar o resultado da forma mais rápida e com menos custos ao Estado e às partes. Assevera Scarance Fernandes que será eficiente o processo que, em tempo razoável, permitir um resultado justo, seja possibilitando aos órgãos da persecução penal agir para fazer atuar o direito punitivo, seja assegurando ao acusado as garantias do processo legal ${ }^{113}$.

No processo civil as últimas alterações legislativas eliminaram etapas do procedimento, até mesmo extinguindo-as com a execução de título judicial, ao unificar no processo de conhecimento as duas fases de julgamento e execução do próprio julgado.

No processo penal não é outra a preocupação, na medida em que a população clama por rigor na aplicação da lei penal instituindo movimentos como o do Direito Penal do Inimigo.

Evidente que não se pode pensar tudo isso e, ao mesmo tempo ${ }^{114}$, olvidar-se das garantias constitucionais previstas ao réu no processo penal. São as limitações do poder estatal em detrimento dos direitos assegurados para a liberdade individual. Não se pode ignorar a exigência de assegurar ao investigado, ao acusado e ao condenado a aplicação

\footnotetext{
${ }^{113}$ FERNANDES, Antonio Scarance. O equilíbrio entre a eficiência e o garantismo e o crime organizado. Revista Brasileira de Ciências Criminais, São Paulo, ano 16, n. 70, jan./fev. 2008, p. 234.

${ }^{114}$ A compreensão de toda e qualquer instituição de direito público, positivamente adotada por um povo, depende da prévia percepção dos princípios fundamentais postos na sua base por esse mesmo povo, na sua manifestação política plena: a Constituição (ATALIBA, Geraldo. República e Constituição. 2. ed. atualizada por Rosolea Miranda Folgosi. São Paulo: Malheiros, 1998. p. 15).
} 
das garantias fundamentais do devido processo legal, o que faz surgir a necessidade do equilíbrio entre essas duas forças jurídicas ${ }^{115}$.

Segundo Scarance Fernandes, não é a criminalidade de bagatela ${ }^{116}$ ou a criminalidade comum ${ }^{117}$ que estabelecem a dificuldade de se definir o ponto de equilíbrio necessário entre a eficiência e o garantismo, mas o campo de aplicação da lei para o crime $\operatorname{organizado}^{118}$.

O princípio da proporcionalidade deve ser invocado para a aplicação das medidas excepcionais que buscam eficiência no processo penal, a fim de que não sejam confrontados os princípios do direito à liberdade e à segurança jurídica. Trata-se, entretanto, não de utilizar a proporcionalidade para flexibilizar a lei em prol da instrumentalidade punitiva, o que confrontaria o princípio da legalidade ${ }^{119}$, mas de solucionar colisões de direitos, bens, interesses ou valores ${ }^{120}$.

A aplicação do princípio da proporcionalidade somente ocorre, no entanto, com a presença de requisitos específicos da adequação, da necessidade e da proporcionalidade em sentido estrito $^{121}$, aplicados de forma sucessiva e apenas se passa ao seguinte com o preenchimento adequado e suficiente do anterior.

A adequação, também chamada de idoneidade, significa que toda intervenção nos direitos fundamentais deve ser adequada para contribuir à obtenção de fim constitucionalmente legítimo ${ }^{122}$. É exemplo dessa aplicação a possibilidade de interceptação telefônica para os fins de investigação criminal ou instrução processual

\footnotetext{
${ }^{115}$ FERNANDES, Antonio Scarance. O equilíbrio entre a eficiência e o garantismo e o crime organizado. Revista Brasileira de Ciências Criminais, n. 70, p. 234.

116 Trata-se das infrações leves e que atualmente são encaminhadas à transformação em infrações administrativas ou se evita a instauração do processo ou, ainda, são aplicadas as medidas alternativas de pena como as restritivas de direitos (ibidem, p. 231).

${ }^{117}$ A criminalidade comum é a que atua no sistema tradicional de regime progressivo de pena e prisão processual excepcional (ibidem, p. 232).

${ }_{118}^{18}$ Ibidem, p. 233.

${ }^{119}$ PACHECO, Denílson Feitoza. O princípio da proporcionalidade no direito processual penal brasileiro. Rio de Janeiro: Lumen Juris, 2007, p. 90, onde especifica: "A aplicação do princípio da proporcionalidade evidencia que seu caráter formal não possibilita um processo penal meramente punitivo, uma vez que o caráter jurídico dos próprios direitos fundamentais, enquanto entes normativos submetidos ao princípio da proporcionalidade, especialmente [...] fundamentalidade, multifuncionalidade e integralidade, compele a persecução criminal a um processo penal garantista de direitos fundamentais".

${ }^{120}$ Ibidem, p. 3.

${ }^{121}$ Também chamados de regras ou subprincípios (ibidem, p. 150).

${ }^{122}$ Ibidem, p. 153. Significa dizer que o fim só é legítimo quando não está proibido explícita ou implicitamente pela Constituição (ibidem, p. 154).
} 
penal, mediante autorização judicial, medida expressamente prevista no artigo $5^{\circ}$, inciso XII, da Constituição Federal.

A retirada do réu da audiência para a oitiva de testemunha protegida respeita ao subprincípio da adequação? Crê-se que sim, pois ainda que seja direito do réu a sua presença física na sala de audiência para acompanhar a prova, a Constituição Federal não impõe como regra absoluta e permite tal circunstância.

A regra da necessidade significa que, na intervenção dos direitos fundamentais, a medida escolhida deve ser a mais branda, benigna ou menos gravosa ${ }^{123}$. Diante daquelas possibilidades de intervenção, deverá o legislador ou o julgador, nos variados momentos da norma, escolher a medida que menos prejudique o direito fundamental que está a ser violado.

Isso parece ter ocorrido com a alteração recente do artigo 217 do Código de Processo Penal, em que a simples retirada do acusado da sala de audiência foi substituída inicialmente pela realização do ato mediante aplicação da tecnologia da videoconferência. Ou seja, entre impedir simplesmente a presença física do acusado e possibilitar outra forma de acompanhamento da audiência, esta última foi a preferida pelo legislador.

Caberá ao juiz, no caso concreto, verificar quais as situações específicas que se mostram a fim de escolher a medida própria e menos gravosa aos direitos fundamentais do acusado.

Por último, o subprincípio da proporcionalidade stricto sensu, pelo qual a importância da intervenção no direito fundamental deve estar justificada pela importância da realização do fim perseguido pela intervenção estatal na circunstância ${ }^{124}$.

${ }^{123}$ PACHECO, Denílson Feitoza. O princípio da proporcionalidade no direito processual penal brasileiro, p. 199. O princípio da necessidade, também denominado "de intervenção mínimna", "da alternativa menos gravosa" ou "de subsidiariedade", é um subprincípio constitucional da proibição de excesso que tende à otimização do grau de eficácia dos direitos individuais em face das limitações que possam impor, em seu exercício, os poderes públicos. Obriga os órgãos do Estado a comparar as medidas restritivas aplicáveis que sejam suficientemente aptas para a satisfação do fim perseguido e a eleger, finalmente, aquela que seja menos lesiva para os direitos do cidadão (ibidem, p. 199).

124 Ibidem, p. 211. Com amparo em Gonzalez-Cuellar Serrano, Pacheco diz: "O princípio da proporcionalidade em sentido estrito é o terceiro subprincípio do princípio constitucional da proibição de excesso ou proporcionalidade em sentido amplo e se aplica, uma vez aceita a idoneidade e necessidade de uma medida, com o fim de determinar, mediante a utilização das técnicas do contrapeso de bens e valores e da ponderação de interesses segundo as circunstâncias do caso concreto, se o sacrifício dos interesses individuais que comporta a ingerência guarda uma relação razoável ou proporcional com a importância do interesse estatal que se trata de salvaguardar. Se o sacrifício resulta excessivo, a medida deverá considerar-se 
Essa regra tem aplicação mais complicada, na medida em que se trabalha com a dimensão dos "pesos" ou "importância" dos valores em equilíbrio. Em verdade, esse conflito não pode ser solucionado com base em precedência absoluta de um só dos valores, ou seja, nenhum valor goza, por si só, de prioridade absoluta. Tal conflito tem como premissa um sopesamento que define qual dos valores tem maior peso no caso concreto, se em termos abstratos estão no mesmo nível ${ }^{125}$.

Segundo Scarance Fernandes, não se trata de uma ponderação abstrata e genérica entre o direito a obter ou produzir prova criminal e o direito fundamental do indivíduo, mas de uma verificação do justo equilíbrio em cada caso ${ }^{126}$.

Eduardo Araújo Silva identifica quatro critérios para sopesar a importância dos interesses em equilíbrio:

- consequência jurídica;

- importância da causa;

- grau de imputação; e

- $\quad$ exito previsível da medida ${ }^{127}$.

Pela consequência jurídica, qualquer restrição a direito ou garantia individual somente pode ocorrer se for proporcional à pena prevista para a infração penal apurada ${ }^{128}$.

inadmissível, embora satisfaça o resto de pressupostos e requisitos derivados do princípio da proporcionalidade" (PACHECO, Denílson Feitoza. O princípio da proporcionalidade no direito processual penal brasileiro, p. 212).

${ }^{125}$ ALEXY, Robert. Teoria dos direitos fundamentais. Tradução de Virgílio Afonso da Silva. 5. ed. São Paulo: Malheiros, 2008. p. 95. Descreve ainda o autor: "Se esse sopesamento levar à conclusão de que os interesses do acusado, que se opõem à intervenção, têm, no caso concreto, um peso sensivelmente maior que os interesses em que se baseia a ação estatal, então, a intervenção estatal viola o princípio da proporcionalidade e, com isso, o direito fundamental do acusado que deriva do art. $2^{\underline{o}}$, § $2^{\underline{o}}$, 1 , da Constituição. Essa situação de decisão corresponde exatamente à colisão entre princípios. As diferenças são de caráter terminológico. Na decisão não se fala em 'colisão', mas de uma 'situação de tensão' e de um 'conflito'; e aquilo que colide e que é sopesado não é caracterizado como 'princípio', mas como 'dever', 'direito fundamental', 'pretensão' e 'interesse'. Mas a caracterização da situação decisória como uma colisão de princípios é perfeitamente possível. Isso ocorre quando se fala, de um lado, do dever de garantir, na maior medida possível, a operacionalidade do direito penal e, de outro lado, do dever de manter incólume, na maior medida possível, a vida e a integridade física do acusado. Esses deveres devem ser aplicados na medida das possibilidades fáticas e jurídicas de sua realização".

${ }^{126}$ FERNANDES, Antonio Scarance. O equilíbrio entre a eficiência e o garantismo e o crime organizado. Revista Brasileira de Ciências Criminais, n. 70, p. 239.

${ }^{127}$ SILVA, Eduardo Araújo. Crime organizado, p. 59.

${ }^{128}$ Ibidem, loc. cit. 
Não é, assim, possível determinar prisão provisória em investigação de crime que sequer prevê pena privativa de liberdade, v.g., artigo 28 da Lei de Drogas.

Para a importância da causa, exige-se a análise sobre a gravidade da infração penal apurada, confrontada com a intensidade da restrição do direito individual ${ }^{129}$. Em razão disso, algumas medidas somente são aplicadas aos crimes previstos em um catálogo, como é exemplo a lei de crimes hediondos, que estipulou exatamente a lista de crimes que permite a aplicação ou não dos institutos ali arrolados.

Pelo grau de imputação, que consiste na ponderação a respeito da força da suspeita sobre a autoria ou a participação no fato investigado, é possível avaliar antecipadamente a probabilidade de uma futura condenação ${ }^{130}$.

Por fim, há o êxito previsível da medida, que exige do aplicador a análise ou aferição de previsibilidade sobre o êxito na medida em que impõe, pois, se nenhum resultado positivo for esperado, a medida não deve ser implementada, ainda que todos os demais requisitos e subprincípios estejam presentes ${ }^{131}$.

A aplicação desses critérios para a efetividade do processo penal é de extrema importância, notadamente nos casos de crime organizado. É essencial para a sobrevivência do crime organizado a manutenção de sua agressividade contra membros e eventuais testemunhas, pois importante a atuação que evite o encontro de provas dos crimes praticados. Em razão disso, faz com que desapareçam instrumentos, estabelece a lei do silêncio, intimida testemunhas, rastreia, com o auxílio de tecnologias avançadas, os locais de reunião para evitar interceptação e se utiliza de vários meios tecnológicos para a comunicação entre os inúmeros membros. Os mecanismos criados pelo Estado tentam evitar o crescimento do crime organizado, prevenindo-o e reprimindo-o ${ }^{132}$.

São vários os mecanismos entabulados pela lei recentemente, como os meios de obtenção de prova não específicos, com acesso a dados, documentos e informações fiscais, bancárias, financeiras e eleitorais (Lei $\mathrm{n}^{\underline{0}}$ 9.034/95), interceptação ambiental (Lei $\mathrm{n}^{\mathrm{o}}$

\footnotetext{
${ }^{129}$ SILVA, Eduardo Araújo. Crime organizado, p. 60.

${ }^{130}$ Ibidem, loc. cit.

${ }^{131}$ Ibidem, p. 61.

${ }^{132}$ FERNANDES, Antonio Scarance. O equilíbrio entre a eficiência e o garantismo e o crime organizado. Revista Brasileira de Ciências Criminais, n. 70, p. 245.
} 
9.296/96) ou os meios de obtenção da prova específicos, como ação controlada, infiltração de agentes, colaboração processual e regras excepcionais na colheita da prova.

Para este trabalho, interessam somente as regras excepcionais de produção da prova testemunhal, a colaboração processual e a delação premiada, e que são estudadas em capítulos próprios, analisadas à luz da doutrina e da legislação vigente. 


\section{MEDIDAS ESPECIAIS DE PROTEÇÃO}

A apuração, investigação, descoberta da verdade e devida punição do agente criminoso são posturas cada vez mais exigidas pela sociedade brasileira. É irrefutável o anseio social pela verificação de um sistema efetivo não só de segurança pública, mas também de repressão ao crime praticado.

É, contudo, proporcional a dificuldade encontrada pelos operadores do direito com a efetividade do processo penal, dado que a agressividade e ousadia dos agentes criminosos prejudicam a colheita das provas.

Não é possível investigar, descobrir a verdade e punir sem que a instrução processual seja efetuada com acurácia, garantindo em especial a perfeição na colheita da prova oral, como já se verificou em capítulos precedentes deste estudo.

O sistema de provas do processo penal permite ao operador trazer ao julgamento os mais variados elementos para convicção e convencimento do julgador, mas às vezes tudo isso fica muito reduzido, na medida em que o delito é praticado e o agente conta com o sigilo absoluto dos envolvidos.

A prova testemunhal é de importância ímpar, mormente para a comprovação da autoria e muitas vezes o depoimento de testemunhas e da própria vítima ficam prejudicados, embora se considere um dever cívico a prestação, por parte das pessoas que presenciaram os fatos, de suas declarações na polícia e em Juízo.

A impunidade é inevitável em razão do receio de tais pessoas das ameaças e represálias, mormente quando se tratar de envolvimento do crime organizado.

É muito comum, notadamente nos casos de crimes dolosos contra a vida, que testemunhas vivam no mesmo distrito da culpa. É possível atribuir a isso a impossibilidade de se alcançar a prova absoluta sobre a autoria por simples medo ou receio diante de ameaças concretas.

Proteger vítimas, testemunhas e réus colaboradores pode, portanto, ser uma medida eficiente na busca da verdade e da efetiva punição do agressor. Decomain conclui que há, 
"mais até do que a utilidade, a necessidade mesmo, em situações mais agudas, de que vítimas e testemunhas recebam proteção que lhes garanta a segurança e a tranquilidade para prestarem seus depoimentos, em prol da administração da Justiça Criminal" "133.

Em vista disso, foi promulgada a Lei $\mathrm{n}^{\mathrm{o}}$ 9.807, em 13 de julho de 1999, a qual estabelece normas para a organização e a manutenção de programas especiais de proteção a vítimas e a testemunhas ameaçadas.

Interessante observar que a lei não delimita os casos em que vítimas e testemunhas devem ser protegidas, muito menos cataloga crimes, como é comum em diplomas que estabelecem normas processuais agressivas, mas a "gravidade da coação ou da ameaça à integridade física ou psicológica, a dificuldade de preveni-las ou reprimi-las pelos meios convencionais e a sua importância para a produção da prova" (art. $2^{\underline{o}}$ ).

Verifica-se, então, que a lei tem por escopo possibilitar à testemunha um meio seguro de poder contribuir com a investigação, apuração e punição ao crime com suas declarações em Juízo ou na polícia, sem ficar à mercê das ameaças e de eventual mal injusto do agressor que vise à impunidade.

Outros países já adotam o mecanismo há mais tempo e serão analisados adiante.

\subsection{A Lei no 9.807/99}

A lei promulgada em 13 de julho de 1999 cria programas especiais de proteção que estabelecem medidas de assistência visando excluir os riscos sofridos pelas testemunhas e vítimas coagidas ou expostas ao perigo em decorrência de colaboração com a investigação ou no processo penal.

O objetivo foi criar mecanismos eficazes de proteção a testemunhas e vítimas que, em razão da importância de seus depoimentos no processo penal, provocam os delinquentes perigosos e, com frequência, organizados.

${ }^{133}$ DECOMAIN, Pedro Roberto. Proteção a testemunhas: redução de pena para o acusado que colabora com a investigação criminal. Revista do Ministério Público/Ministério Público do Estado do Rio de Janeiro, n. 12, p. 144. 
A proteção, segundo a lei em comento, será executada mediante providências específicas que vão desde o abrigo temporário com vigilância ininterrupta para a testemunha e seus familiares até a substituição do próprio nome da pessoa, bem como seus documentos e toda identificação civil.

Convém esclarecer que a Lei $\mathrm{n}^{\circ}$ 9.807/99 foi regulamentada pelo Decreto 3.518, de 20 de junho de 2000, e que também deverá ser citado neste estudo.

\subsubsection{Legitimidade para o requerimento}

Segundo o artigo $1^{\circ}$ da Lei, a proteção pode ser requerida pela vítima ou testemunha que se sentir ameaçada ou sofrer qualquer coação. Não significa, portanto, aplicação automática da proteção, nem tampouco "oferecimento" por parte da autoridade policial. Esse já é um requisito necessário, pelo qual a vítima ou testemunha deve "querer" a proteção, mesmo porque, como se verá, ela deve encaixar-se nos vários requisitos do programa e cumprir rigorosamente com as obrigações que lhe são impostas:

"O ingresso no programa, as restrições de segurança e demais medidas por ele adotadas terão sempre a anuência da pessoa protegida, ou de seu representante legal.

Após ingressar no programa, o protegido ficará obrigado ao cumprimento das normas por ele prescritas.

As medidas e providências relacionadas com os programas serão adotadas, executadas e mantidas em sigilo pelos protegidos e pelos agentes envolvidos em sua execução." (artigo $2^{\underline{o}}$, $\S \S 3^{\circ}, 4^{\underline{0}}$ e $5^{\circ}$, Lei $n^{\circ}$ 9.807/99)

Insta também salientar, que a vítima ou testemunha não podem ser compelidas a aceitar a proteção se realmente não quiserem. É diferente da obrigação de depor, na qual o comparecimento e a declaração dos fatos que sabe verdadeiros são devidos no processo penal. 
Não é rara a situação da testemunha incluída no programa de proteção que desiste ao conhecer as restrições à vida cotidiana.

O pedido, entretanto, segundo a vontade do interessado, poderá ser efetuado, nos termos do artigo $5^{\circ}$ da Lei, pelo interessado; por representante do Ministério Público; pela autoridade policial que conduz a investigação criminal; pelo juiz competente para a instrução do processo criminal; e por órgãos públicos e entidades com atribuições de defesa dos direitos humanos.

O mesmo artigo define que "a solicitação será instruída com a qualificação da pessoa a ser protegida e com informações sobre a sua vida pregressa, o fato delituoso e a coação ou ameaça que a motiva".

\subsubsection{Critérios e requisitos para inclusão}

Verifica-se, de início, que a lei estipula critérios objetivos e subjetivos para a inclusão no programa de proteção da vítima ou testemunha. Prevê o artigo $1^{1}$, que as medidas de proteção serão requeridas por vítimas ou testemunhas que estejam coagidas ou expostas a grave ameaça em razão de colaborarem com investigação em processo criminal. $\mathrm{O}$ artigo $2^{\underline{o}}, \S 2^{\underline{o}}$, estipula que ficam excluídos os indivíduos cuja personalidade ou conduta sejam incompatíveis com as restrições de comportamento exigidas no programa ou acusados sob prisão cautelar em qualquer modalidade. Por último, o artigo 15, no capítulo da proteção aos réus colaboradores, prevê medidas especiais de segurança e proteção à integridade do colaborador efetivo na investigação e processo criminal.

Para sistematizar, é, dessa forma, possível estabelecer, preliminarmente, um rol de requisitos para a inclusão no programa de proteção. Salienta-se, no entanto, que nessa descrição inicial ficarão de fora dos parâmetros os réus colaboradores, em razão de o instituto requerer estudo separado:

- ser vítima ou testemunha de crime que possam colaborar em investigação ou processo criminal; 
- ter sido coagida ou exposta a grave ameaça;

- não ter personalidade ou conduta incompatível com as restrições de comportamento exigidas no programa; e

- não ser condenado cumprindo pena e não estar sob prisão cautelar, seja qual for a modalidade.

\subsubsection{Ser vítima ou testemunha de crime que possam colaborar em investigação ou processo criminal}

As características principais da vítima ou ofendido e da testemunha já foram estudadas no capítulo próprio da prova testemunhal. Cabe, então, analisar outros itens do requisito estabelecido pela lei.

O termo "crime" induz, numa interpretação meramente gramatical, que somente ocorrência de crime, stricto sensu, autorizaria a inclusão de testemunha na proteção estatal, deixando fora situações como as de contravenções.

Todavia, ao verificar que a lei trata em especial de proteção de vítimas e testemunhas ameaçadas, bem como a falta de estipulação específica de crimes, tem-se que o termo "crime" do primeiro artigo teria o sentido lato de "delito", pois não seria crível que uma testemunha de uma contravenção, uma vez ameaçada, não pudesse ser incluída na proteção estatal, ainda que se tenham situações menos graves.

O fato único de a testemunha ter presenciado uma contravenção, por sua vez, não significa que o contraventor não seja uma pessoa perigosa e que subjacente àquele delito não existam outros mais graves ou mesmo uma organização criminosa.

É oportuno lembrar que a prática do "jogo do bicho" constitui, ainda, uma contravenção, mas que esconde verdadeiras empresas criminosas. 
O requisito também estabelece, nas palavras da lei, vítimas e testemunhas que estejam coagidas ou expostas a grave ameaça em "razão de colaborarem" com a investigação ou processo criminal.

Testemunhas e vítimas colaboram? Colaborar significa auxílio voluntário?

Trata-se de um aspecto muito importante a ser analisado, pois a testemunha só é testemunha após constar de rol da denúncia ou, antes mesmo, na investigação já pode ser assim classificada? A testemunha que nada sabe sobre os fatos ou sabe muito pouco, mas que foi arrolada na denúncia, também pode ser incluída no programa de proteção?

Colaborar significa que suas declarações são relevantes para o contexto probatório. Não se trata de uma testemunha de "ouvir dizer", nem tampouco desconhece os fatos como ocorreram. Colaborar tem um sentido positivo de trazer aos autos informações importantes sobre a ocorrência do crime e sua autoria.

Como já se verificou, testemunha, no sentido próprio da palavra, é a pessoa chamada a depor acerca de determinado fato, ao passo que vítima é a pessoa titular do direito violado pela prática do delito.

Cabe, ainda, salientar que a testemunha é chamada a depor pelos fatos que teve conhecimento por quaisquer de seus sentidos: visão, audição, tato, olfato ou, ainda, paladar.

Difícil, assim, estabelecer que uma pessoa chamada a depor não possa ser alvo de ameaça ou constrangimento por essa posição. Ademais, não é coerente proceder à inclusão de uma pessoa que nada ou pouco e de irrelevância possa trazer à investigação criminal ou ao processo no sistema de proteção.

Conclui-se, pois, que toda e qualquer pessoa chamada a depor, ainda que seja na fase inquisitorial, somente para efeito de investigação, e que possa trazer algum fato relevante - daí o significado de "colaborar" -, pode e deve ser objeto de proteção do Estado.

Por fim, salienta-se a possibilidade da proteção desde logo na fase da investigação criminal. 
Outra questão aqui, entretanto, gera dúvida: seria possível estabelecer a proteção do mecanismo estudado em face de uma testemunha coagida ou exposta a grave ameaça em processo de natureza cível?

Entende-se, neste estudo, que não. Em primeiro lugar, não caberia a aplicação do instituto sob o prisma do princípio da proporcionalidade, dado o caráter particular da discussão do direito privado e, ainda que haja interesse público, o contraditório não poderia ser mitigado.

Também não é da exegese do dispositivo legal a aplicação a toda e qualquer discussão judicial, estipulando o artigo $1^{\circ}$, da Lei nº 9.807/99 a colaboração de testemunha ou vítima em investigação ou processo criminal.

\subsubsection{Ter sido coagida ou exposta a grave ameaça}

Outro requisito para inclusão da testemunha ou vítima em proteção estatal é o constrangimento ilegal caracterizado pela coação ou exposição a grave ameaça.

\subsubsection{Não ter personalidade ou conduta incompatível com as restrições de comportamento exigidas no programa}

Este requisito somente pode ser analisado após o conhecimento total das restrições de comportamento exigidas pelo programa. Depois, especificamente o comportamento e a conduta do protegido são de ordem subjetiva.

A primeira grande restrição do programa é o sigilo. Entende-se que esse é caráter imprescindível para a manutenção do programa, até mesmo para que seja bem-sucedido. Descreve o artigo $2^{\circ}$, $\S 5^{\circ}$, da lei: “As medidas e providências relacionadas com os programas serão adotadas, executadas e mantidas em sigilo pelos protegidos e pelos agentes envolvidos em sua execução". 
Conclui Decomain a respeito do sigilo:

"As medidas acautelatórias inerentes ao programa devem ser mantidas em sigilo tanto pelos protegidos quanto pelos protetores. Essa a regra do $\S 5^{0}$ do artigo, que se explica pela própria razão de ser do programa: proteger a pessoa contra a investida daqueles que tenham interesse em impedir que seu depoimento venha à tona, porque prejudicial a eles. Se houvesse alarde em torno das medidas protetivas adotadas, fosse por parte de seus protegidos, a eficácia do programa poderia ficar comprometida, principalmente quando se cuidasse de manter o protegido em local seguro e desconhecido daqueles que teriam interesse em intimidá-lo ou até em impor-lhe mal maior"134.

O Decreto 3.518 também fez previsão ao sigilo e regulamentou da seguinte forma:

“Art. 15. O Conselho, o Órgão Executor, o Serviço de Proteção e demais órgãos e entidades envolvidos nas atividades de assistência e proteção aos admitidos no Programa devem agir de modo a preservar a segurança e a privacidade dos indivíduos protegidos.

Parágrafo único - Serão utilizados mecanismos que garantam a segurança e o sigilo das comunicações decorrentes das atividades de assistência e proteção.

$(\ldots)$

Art. 17. A gestão de dados pessoais sigilosos deve observar, no que couber, as medidas de salvaguarda estabelecidas pelo Decreto $\mathrm{n}^{\mathrm{o}} 2.910$, de 29 de dezembro de 1998.

$\S 1^{\underline{0}}-\mathrm{O}$ tratamento dos dados a que se refere este artigo deve ser processado por funcionários previamente cadastrados e seu uso, autorizado pela autoridade competente, no objetivo de assegurar os direitos e as garantias fundamentais do protegido.

$\S 2^{\underline{o}}$ - Os responsáveis pelo tratamento dos dados pessoais dos indivíduos protegidos, assim como as pessoas que, no exercício de suas funções, tenham conhecimento dos referidos dados, estão obrigados a manter

\footnotetext{
${ }^{134}$ DECOMAIN, Pedro Roberto. Proteção a testemunhas: redução de pena para o acusado que colabora com a investigação criminal. Revista do Ministério Público/Ministério Público do Estado do Rio de Janeiro, n. 12, p. 151.
} 
sigilo profissional sobre eles, inclusive após o seu desligamento dessas funções.

$\S 3^{0}$ - Os responsáveis por tratamento de dados a que se refere este artigo devem aplicar as medidas técnicas e de organização adequadas para a proteção desses dados contra a destruição, acidental ou ilícita, perda, alteração, divulgação ou acesso não autorizado." (sem grifos no original)

Verifica-se, de início, a salvaguarda da "privacidade" das pessoas dos protegidos, significando que o sigilo não resguarda a somente um protegido, mas a todos. O protegido poderá, muitas vezes, ser mantido em habitação coletiva e, com isso, a quebra de sigilo não coloca somente a sua pessoa em risco, mas de todos que ali estão na mesma situação.

A cautela é, ainda, necessária em relação às pessoas encarregadas da manutenção da proteção, que também serão alvos dos delinquentes ameaçadores e dependem da mesma garantia de segredo de suas identidades e locais de residência.

O Regulamento também faz previsão ao sigilo de comunicações e toda forma de ligação do protegido com o órgão executor responsável pela proteção.

Como se verifica pelo texto do artigo 17, os funcionários responsáveis pela guarda ou utilização dos dados pessoais dos protegidos, que naturalmente também são sigilosos, ficam submetidos ao sigilo profissional, incidindo, assim, na obrigação de manter o segredo, sob pena de incidir nas sanções do artigo que prevê o crime de sigilo profissional.

$\mathrm{O} \S 3^{\circ}$ do artigo em comento não admitirá nem mesmo a justificativa de vazamento culposo de tais informações.

O sigilo, por óbvio, não será a única restrição imposta ao protegido, eis que, dependendo da providência tomada, ou seja, variam as necessidades pelas medidas acautelatórias adotadas em cada caso.

É de se verificar que a retirada do protegido de seu local de habitação atual será a medida mais eficaz para sua proteção. Isso, naturalmente, acarretará uma série de providências de logística para a adaptação, o que também impõe restrições ao protegido.

Descreve, v.g., o decreto regulamentador: 
"Art. 16 - Os deslocamentos de pessoas protegidas para o cumprimento de atos decorrentes da investigação ou do processo criminal, assim como para compromissos que impliquem exposição pública, são precedidos das providências necessárias à proteção, incluindo, conforme o caso, escolta policial, uso de colete à prova de balas, disfarces e outros artifícios capazes de dificultar sua identificação.”

Ora, caberá ao protegido se adaptar a essas necessidades e não poderá deixar de cumprir com os cuidados necessários para seu deslocamento, seja para o depoimento judicial propriamente, seja, ainda, para outros compromissos.

Como se verá no item 8.1.5 deste Capítulo, o descumprimento de tais restrições acarretará a exclusão do protegido do programa.

\subsubsection{Não ser condenado cumprindo pena e não estar sob prisão cautelar, seja qual for a modalidade}

Tem-se, por fim, o requisito especial para as vítimas e testemunhas que eventualmente estejam cumprindo pena ou sob prisão processual.

Isso é possível. Evidente que não se fala do mesmo processo em que a pessoa é vítima ou testemunha, mas por outros motivos, e isso impedirá a inclusão da testemunha no programa, até mesmo por razões óbvias.

O programa de proteção a testemunhas é executado de acordo com as providências estabelecidas na lei. Por certo, não há possibilidade de manutenção de pessoa no programa com a cautela necessária se ela estiver impossibilitada de ser deslocada ou protegida. Isso ocorre para as pessoas presas, pois não é compatível com as medidas acautelatórias, a prisão da pessoa do protegido.

A lei ressalva, todavia, a necessidade de medidas no âmbito prisional, seja ao apenado, seja ao que somente responde ao feito criminal, descrevendo que "tal exclusão não trará prejuízo a eventual prestação de medidas de preservação da integridade física 
desses indivíduos por parte dos órgãos de segurança pública" (art. $2^{\circ}, \S 2^{\circ}$, parte final, Lei $\mathrm{n}^{\mathrm{o}}$ 9.807/99). Na parte referente ao réu colaborador, descreve ainda o diploma legal, medidas especiais ao que estiver em cumprimento de pena ou prisão cautelar (art. 15), mas esse estudo será efetuado em profundidade no Capítulo 9.

O decreto regulamentador cria uma figura não prevista na Lei, que é o chamado “depoente especial”. Inclui nessa figura o réu colaborador, estudado adiante na delação premiada, bem como "a pessoa que, não admitida ou excluída do Programa, corra risco pessoal e colabore na produção da prova" (art. 10).

Para tais "depoentes especiais", o regulamento fez previsão para algumas medidas acautelatórias de proteção, de acordo com a necessidade e situação de cada um. Na dicção do artigo 10 do Decreto em comento:

“(...) Entende-se por depoente especial:

I - o réu detido ou preso, aguardando julgamento, indiciado ou acusado sob prisão cautelar em qualquer de suas modalidades, que testemunhe em inquérito ou processo judicial, se dispondo a colaborar efetiva e voluntariamente com a investigação e o processo criminal, desde que dessa colaboração possa resultar a identificação de autores, co-autores ou partícipes da ação criminosa, a localização da vítima com sua integridade física preservada ou a recuperação do produto do crime; e

II - a pessoa que, não admitida ou excluída do Programa, corra risco pessoal e colabore na produção da prova.

Art. 11 - O Serviço de Proteção ao Depoente Especial consiste na prestação de medidas de proteção assecuratórias da integridade física e psicológica do depoente especial, aplicadas isoladas ou cumulativamente, consoante as especificidades de cada situação, compreendendo, dentre outras:

I - segurança na residência, incluindo o controle de telecomunicações;

II - escolta e segurança ostensiva nos deslocamentos da residência, inclusive para fins de trabalho ou para a prestação de depoimentos;

III - transferência de residência ou acomodação provisória em local compatível com a proteção; 
IV - sigilo em relação aos atos praticados em virtude da proteção concedida; e

V - medidas especiais de segurança e proteção da integridade física, inclusive dependência separada dos demais presos, na hipótese de o depoente especial encontrar-se sob prisão temporária, preventiva ou decorrente de flagrante delito.

$\S 1^{\text {o }}$ - A escolta de beneficiários do Programa, sempre que houver necessidade de seu deslocamento para prestar depoimento ou participar de ato relacionado a investigação, inquérito ou processo criminal, será efetuada pelo Serviço de Proteção.

$\S 2^{\underline{o}}$ - Cabe ao Departamento de Polícia Federal, do Ministério da Justiça, o planejamento e a execução do Serviço de Proteção, para tanto podendo celebrar convênios, acordos, ajustes e termos de parceria com órgãos da Administração Pública e entidades não-governamentais.

Art. 12 - $\mathrm{O}$ encaminhamento das pessoas que devem ser atendidas pelo Serviço de Proteção será efetuado pelo Conselho e pelo Ministro de Estado da Justiça.

Parágrafo único - $\mathrm{O}$ atendimento pode ser dirigido ou estendido ao cônjuge ou companheiro, descendente ou ascendente e dependentes que tenham convivência habitual com o depoente especial, conforme o especificamente necessário em cada caso.

Art. 13 - A exclusão da pessoa atendida pelo Serviço de Proteção poderá ocorrer a qualquer tempo:

I - mediante sua solicitação expressa ou de seu representante legal;

II - por decisão da autoridade policial responsável pelo Serviço de Proteção; ou

III - por deliberação do Conselho.

Parágrafo único - Será lavrado termo de exclusão, nele constando a ciência do excluído e os motivos do ato.

Art. 14 - Compete ao Serviço de Proteção acompanhar a investigação, o inquérito ou processo criminal, receber intimações endereçadas ao depoente especial ou a quem se encontre sob sua proteção, bem como 
providenciar seu comparecimento, adotando as medidas necessárias à sua segurança." (sem grifos no original)

Verifica-se que, mesmo aqueles não admitidos no programa ou excluídos em razão do cumprimento de pena ou de prisão cautelar, ainda assim poderão ser protegidos na medida da necessidade de cada um.

Para finalizar essa questão, cabe somente a seguinte indagação: quando a lei estipula o impedimento de inclusão de "condenados que estejam cumprindo pena" inclui também aqueles que não foram condenados a pena privativa de liberdade, a exemplo de penas alternativas como as restritivas de direito?

Entende-se, neste estudo, que sim. Como se verificou, o impedimento foi estipulado pela lei em razão da incompatibilidade das medidas acautelatórias e a impossibilidade de liberdade total do protegido para ser retirado de seu local de habitação ou domicílio e naturalmente o cumprimento de pena restritiva de direito não possibilitará essa liberdade necessária.

Em relação aos critérios estipulados para o Conselho Deliberativo, descreve o caput do artigo $2^{\underline{0}}$ da Lei $\mathrm{n}^{\mathrm{o}}$ 9.807/99:

"A proteção concedida pelos programas e as medidas dela decorrentes levarão em conta a gravidade da coação ou da ameaça à integridade física ou psicológica, a dificuldade de preveni-las ou reprimi-las pelos meios convencionais e a sua importância para a produção da prova."

Desse dispositivo se verificam os critérios seguintes que são analisados em termos globais:

- gravidade da coação ou da ameaça à integridade física ou psicológica da pessoa do protegido;

- dificuldade de preveni-las ou reprimi-las pelos meios convencionais; e

- importância da pessoa do protegido ou familiar para a produção da prova. 
Evidente que a análise, nesse caso, passa a ser subjetiva e o Conselho Deliberativo avaliará de acordo com as necessidades de cada situação.

\subsubsection{Procedimento}

O pedido será efetuado pelas pessoas ou entidades arroladas no artigo $5^{\circ}$, da Lei $\mathrm{n}^{\circ}$ 9.807/99, já verificadas no item "legitimidade", sendo o pedido instruído com:

- a qualificação da pessoa a ser protegida;

- as informações sobre sua vida pregressa;

- o fato delituoso; e

- a coação ou ameaça que a motiva.

$\mathrm{O} \S 2^{\underline{0}}$ dispõe que o órgão executor poderá requisitar outras informações, mas com aquiescência do interessado, uma vez que se trata de dados pessoais e exames ou pareceres técnicos sobre a personalidade. Como, no entanto, esse pedido de informações ocorre antes da decisão sobre a inclusão do protegido no programa e compete ao Conselho Deliberativo tomar essa decisão, deve-se entender, aqui, como Conselho Deliberativo, mesmo porque o parágrafo não está fazendo referência àquele órgão de execução previsto no artigo $4^{\underline{0}}, \S 1^{\circ}$.

Antes da decisão, entretanto, o pedido é submetido ao Ministério Público, como determina o artigo 3울 “Toda admissão no programa ou exclusão dele será precedida de consulta ao Ministério Público sobre o disposto no art. $2^{\underline{0}}$ e deverá ser subsequentemente comunicada à autoridade policial ou ao juiz competente".

Importante aqui verificar a presença do Ministério Público no procedimento de admissão. Não se trata aqui do Ministério Público enquanto participante do Conselho Deliberativo, mas da Instituição como parte da relação jurídica processual onde a prova deva ser produzida.

Sobre a questão, observa Decomain: 
"Qual o representante do Ministério Público a ser consultado sobre a inclusão ou exclusão de alguém em programa protetivo? A resposta é simples. O agente da Instituição que deve opinar sobra a matéria será o mesmo a quem já incumbe ou virá a incumbir oficiar no processo criminal ao qual a vítima ou testemunha se acha ligada. Em se tratando de solicitação formulada ainda na fase de inquérito ou outras investigações, o pedido deve ser normalmente distribuído. Registre-se, todavia, que a distribuição não deve consignar, em hipótese alguma, o nome da pessoa a ser protegida" ${ }^{, 135}$.

Essa manifestação inicial do Ministério Público não vincula o Conselho Deliberativo. Ao contrário, é a manifestação opinativa do Ministério Público sobre a inclusão ou não da pessoa que efetua o pedido de proteção. O membro do Parquet no Conselho Deliberativo, por sua vez, tem voto e será levado em consideração para a decisão, que é sempre tomada por maioria absoluta.

A opinião do promotor de justiça do processo é necessária na medida em que é a pessoa mais qualificada para verificar a importância do depoimento na prova a ser produzida naquela discussão judicial.

Conforme verificou-se alhures, acerca do disposto no artigo $2^{\circ}$ da Lei $n^{\circ}$ 9.807/99, a “importância da pessoa do protegido ou familiar para a produção da prova" é critério analisado para a inclusão no programa.

Para finalizar, é pertinente a observação de que a lei admite providências de urgência dado, em especial, que o Conselho Deliberativo não se reúne a qualquer momento. Com isso, é possível ao seu presidente decidir sobre inclusão ou exclusão provisórias decorrente da existência de risco pessoal.

\footnotetext{
${ }^{135}$ DECOMAIN, Pedro Roberto. Proteção a testemunhas: redução de pena para o acusado que colabora com a investigação criminal. Revista do Ministério Público/Ministério Público do Estado do Rio de Janeiro, n. 12, p. 152.
} 


\subsubsection{Formação do programa}

A Lei $n^{0} 9.807$ prevê a divisão do programa conforme a seguir:

"Art. $4^{\circ}$ - Cada programa será dirigido por um conselho deliberativo em cuja composição haverá representantes do Ministério Público, do Poder Judiciário e de órgãos públicos e privados relacionados com a segurança pública e a defesa dos direitos humanos.

$\S 1^{0}$ - A execução das atividades necessárias ao programa ficará a cargo de um dos órgãos representados no conselho deliberativo, devendo os agentes dela incumbidos ter formação e capacitação profissional compatíveis com suas tarefas."

O Decreto 3.518 faz a seguinte distribuição:

“Art. $2^{\underline{0}}$ - Integram o Programa:

I - o Conselho Deliberativo Federal;

II - o Órgão Executor Federal; e

III - a Rede Voluntária de Proteção.”

A natureza do funcionamento do programa é complexa. $\mathrm{O}$ orçamento para sua manutenção, com o custeio de pessoal e dos dispêndios com os protegidos, é público. De direção mista, na medida em que o Conselho Deliberativo é formado por entidades públicas e privadas, sua execução compete a um ente particular ${ }^{136}$.

A lei não especificou em detalhe a composição do Conselho, justamente para proporcionar certa liberdade aos Estados e Distrito Federal na organização e condução dos trabalhos e serviços de proteção.

A questão poderá ser disciplinada em legislação estadual, mas também por caráter administrativo, eis que o dispositivo deixa ampla a possibilidade de composição, desde que dirigido pelo Ministério Público.

O Decreto regulamentador, no âmbito federal, especifica a formação do Conselho de Sentença, estipulando a presença do Ministério Público, do Poder Judiciário e de órgãos

\footnotetext{
${ }^{136}$ Muito embora a lei faça previsão de execução a qualquer dos órgãos que componham o Conselho Deliberativo, em regra cabe a uma entidade associativa ou não governamental.
} 
públicos e privados relacionados com a segurança pública e a defesa dos direitos humanos. Nesse caso, o Decreto regulamentador estipulou o seguinte na formação do Conselho:

“Art. 7º - O Conselho é composto pelos seguintes membros, designados pelo Ministro de Estado da Justiça:

I - um representante da Secretaria de Estado dos Direitos Humanos;

II - um representante da Secretaria Nacional de Segurança Pública;

III - um representante da Secretaria Nacional de Justiça;

IV - um representante do Departamento de Polícia Federal;

V - um representante do Ministério Público Federal;

VI - um representante do Poder Judiciário Federal, indicado pelo Superior Tribunal de Justiça; e

VII - um representante de entidade não-governamental com atuação na proteção de vítimas e testemunhas ameaçadas, indicado pelo Secretário de Estado dos Direitos Humanos.

Parágrafo único - Os membros do Conselho têm mandato de dois anos, sendo permitida a recondução."

Veja-se que a nomeação será sempre pelo Ministro da Justiça, cabendo a ele a direção do Conselho.

A função do Conselho Deliberativo é primordialmente dirigir o programa, estabelecendo o orçamento e a fiscalização dos dispêndios, além de analisar os pedidos de proteção, a inclusão ou exclusão do programa.

"Art. 6ํㅡ - Ao Conselho Deliberativo Federal, instância de direção superior, compete:

I - decidir sobre os pedidos de admissão e exclusão do Programa;

II - solicitar às autoridades competentes medidas de proteção;

III - solicitar ao Ministério Público as providências necessárias à obtenção de medidas judiciais acautelatórias;

IV - encaminhar as pessoas que devem ser atendidas pelo Serviço de Proteção ao Depoente Especial, de que trata o Capítulo II deste Decreto; 
V - adotar as providências necessárias para a obtenção judicial de alteração da identidade civil;

VI - fixar o valor máximo da ajuda financeira mensal aos beneficiários da proteção; e

VII - deliberar sobre questões relativas ao funcionamento e aprimoramento do Programa.

$\S 1^{0}$ - As decisões do Conselho são tomadas pela maioria dos votos de seus membros.

$\S 2^{\underline{\underline{o}}}-$ O Presidente do Conselho, designado pelo Ministro de Estado da Justiça dentre seus membros, pode decidir, em caráter provisório, diante de situações emergenciais e na impossibilidade de imediata convocação de reunião do Colegiado, sobre a admissão e a adoção de medidas assecuratórias da integridade física e psicológica da pessoa ameaçada."

A execução do programa de proteção, no entanto, caberá a um dos órgãos representados no Conselho Deliberativo (art. $4^{\underline{0}}, \S 1^{\underline{0}}$ ), mas não há especificação se público ou privado, o que leva a estabelecer a possibilidade de execução por associações ou entidades não governamentais.

Imagina-se, dessa forma, que poderá ser chamado a servir no Conselho de Sentença um representante da Igreja Católica, assim entendido, devidamente nomeado pelos cânones próprios e legítimos daquele ente religioso. A execução, por decisão do Conselho, poderá ser atribuída à Igreja, a um ente ligado à Igreja ou a qualquer outro órgão que faça parte do Conselho Deliberativo.

Caberá ao órgão de execução tomar todas as providências necessárias para o cumprimento das determinações do Conselho Deliberativo e fornecer a esse mesmo Conselho relatórios sobre o andamento do programa, prestando contas dos valores utilizados.

Os agentes responsáveis por esse cumprimento deverão estar capacitados tecnicamente para o acompanhamento jurídico e assistencial aos protegidos, além de oferecer apoio psicológico para a manutenção do programa de forma a evitar prejuízos óbvios dada a circunstância especial em que a pessoa se encontra. A eles também caberá o 
apoio para cumprimento de todas as obrigações civis do protegido e sua escolta para o comparecimento em audiências e outros atos processuais de colheita de depoimentos.

Aos agentes de execução, também caberá a formação da Rede Voluntária de Proteção. A Lei n⿳⺈ 9.807/99 não se referiu a essa Rede Voluntária de Proteção, mas o Decreto Federal 3.518 estabeleceu a criação de um

\begin{abstract}
“(...) conjunto de associações civis, entidades e demais organizações nãogovernamentais que se dispõem a receber, sem auferir lucros ou benefícios, os admitidos no Programa, proporcionando-lhes moradia e oportunidades de inserção social em local diverso de sua residência.

Integram a Rede Voluntária de Proteção as organizações sem fins lucrativos que gozem de reconhecida atuação na área de assistência e desenvolvimento social, na defesa de direitos humanos ou na promoção da segurança pública e que tenham firmado com o Órgão Executor ou com entidade com ele conveniada termo de compromisso para o cumprimento dos procedimentos e das normas estabelecidos no Programa.” (artigo $9^{\circ}$ e parágrafo único do Decreto 3.518/2000)
\end{abstract}

O brasileiro é altruísta por natureza. Contando com isso, a legislação fez previsão de associações e pessoas voltadas à ajuda do próximo para contribuir com o programa oferecendo auxílio psicológico e até material aos protegidos. Por óbvio, essas pessoas devem contar com o mesmo sigilo que reveste toda a operação do órgão de execução e não se duvida que esse trabalho será plenamente eficaz.

No Estado de São Paulo existe essa Rede Voluntária de Proteção, que conta com várias pessoas nos locais onde estão os protegidos para auxílio material, psicológico e assistencial.

\title{
8.1.5 Exclusão do programa
}

Em princípio a proteção oferecida pelo programa terá prazo máximo de dois anos, nos termos do artigo 11 da Lei $\mathrm{n}^{\mathrm{o}}$ 9.807/99, podendo esse período ser prorrogado por 
“circunstâncias excepcionais"137. O protegido poderá, no entanto, ser excluído antes desse período nas seguintes situações:

- por solicitação do próprio interessado;

- por decisão do Conselho Deliberativo em consequência de cessação dos motivos que ensejaram a proteção; ou

- por decisão do Conselho Deliberativo em consequência de conduta incompatível do protegido.

As duas primeiras circunstâncias não merecem digressões mais extensas, porém a análise de conduta incompatível do protegido deixa margem para interpretações, pois cabe ao Conselho Deliberativo verificar se o protegido cumpre ou não com as restrições do programa e se pratica atos que possam colocar em risco a sua pessoa, de outros protegidos ou da equipe técnica da execução do programa.

Convém, preliminarmente, estabelecer que devem existir critérios para essa análise e esses critérios serão os mesmos já estabelecidos para a inclusão no programa. Não se trata, portanto, de o Conselho Deliberativo considerar uma conduta própria ou imprópria por seus valores internos.

Imagina-se que eventualmente pessoas com valores religiosos muito rigorosos no Conselho considerem que o protegido não possa, por exemplo, frequentar cultos religiosos diferentes daqueles que os conselheiros professem.

Relembrando os critérios de inclusão já assinalados neste estudo, tem-se que a incompatibilidade inaceitável é somente aquela que confronta as restrições do programa, quais sejam: sigilo, adaptação do protegido às necessidades e aos cuidados para seu deslocamento, bem como não ser condenado cumprindo pena e não estar sob prisão cautelar, independentemente da modalidade.

Talvez outro critério tenha sido estabelecido de forma implícita: a prática de delitos. Por óbvio, o programa não poderá esconder o criminoso que se utilize da proteção para impunidade de seus delitos praticados durante o período de proteção.

\footnotetext{
${ }^{137}$ Em circunstâncias excepcionais, perdurando os motivos que autorizam a admissão, a permanência poderá ser prorrogada (art. 11, parágrafo único, Lei nº 9.807/99).
} 


\subsection{Das medidas protetivas previstas na lei}

A lei fez previsão a tais providências no artigo $7^{\underline{0}}$, mas, é pertinente frisar, não limitou tais providências em numerus clausus, deixando clara a aplicação das medidas, isolada ou cumulativamente, dentre outras, assim compreendidas:

- segurança na residência, incluindo o controle de telecomunicações;

- escolta e segurança nos deslocamentos da residência, inclusive para fins de trabalho ou para prestação de depoimentos;

- transferência de residência ou acomodação provisória em local compatível com a proteção;

- preservação da identidade, imagem e dados pessoais;

- ajuda financeira mensal para prover as despesas necessárias à subsistência individual ou familiar, no caso de a pessoa protegida estar impossibilitada de desenvolver trabalho regular ou de inexistência de qualquer fonte de custeio;

- suspensão temporária das atividades funcionais, sem prejuízo dos respectivos vencimentos ou vantagens, quando servidor público;

- apoio e assistência social, médica e psicológica;

- $\quad$ sigilo em relação aos atos praticados em virtude da proteção concedida;

- apoio do órgão executor do programa para o cumprimento de obrigações civis e administrativas que exijam o comparecimento pessoal;

- alteração do nome do protegido.

\subsubsection{Segurança na residência, incluindo o controle de telecomunicações}

Conforme poderá ser observado, os protegidos em regra são retirados de sua moradia habitual, onde seus agressores podem encontrá-los com facilidade. O inciso II do 
artigo $7^{0}$, todavia, dispõe sobre aquela situação em que o protegido permanece em seu lar, mas a ele é fornecido policiamento, vigia ou outros aparatos de segurança normalmente possíveis e disponíveis no mercado.

A inclusão do controle das telecomunicações significa o monitoramento da comunicação externa, não com o objetivo de analisar as conversas telefônicas ou telemáticas do protegido, mas a tentativa de contato do agressor.

Essa não é uma medida eficiente, pois o protegido continuaria a manter sua identidade, seu endereço, sua profissão e outros vínculos com o mundo externo que o deixam desguarnecido. Há, porém, situações transitórias em que somente essa vigilância já seria suficiente, como é o caso de um marido agressor que tenta voltar à residência do casal. De qualquer sorte, seria possível a identificação de prováveis agressores.

As comunicações telefônicas gozam de sigilo e a própria Constituição Federal assim estabelece. A quebra desse sigilo pode ocorrer, mas somente nas situações previamente estabelecidas como exceções na Carta Maior e mediante autorização judicial. Mas ainda deve-se seguir o procedimento previsto pela Corregedoria do Conselho Nacional de Justiça.

Por outra via, aqui não se prevê a intromissão em ligações telefônicas alheias, mas em ligações efetuadas a um dos interlocutores, que por óbvio autoriza a escuta. Destarte, para tal "controle de comunicações”, dispensável é a autorização judicial.

\subsubsection{Escolta e segurança nos deslocamentos da residência, inclusive para fins de trabalho ou para prestação de depoimentos}

Outra medida transitória e de menor agressividade é a escolta nos deslocamentos, em que o protegido seria acompanhado quando fora da residência ou lugar de proteção.

Nesse caso, a proteção será efetivada também nas situações em que o protegido estiver no local de pouso seguro e sigiloso. Muitas vezes o protegido deverá ser acompanhado para seu depoimento em Juízo e, por óbvio, não poderá se apresentar 
sozinho ao Fórum ou ao Distrito Policial, sob pena de sofrer os riscos de ameaças. Nesse caso, o sigilo do local de moradia protegida também seria prejudicado.

A propósito dessa questão, explica Decomain:

"Seria de pouca valia a proteção em domicílio se não alcançasse também eventuais deslocamentos da pessoa protegida. A escolta e segurança durante esses deslocamentos vêm previstas, como segunda espécie de providência protetiva, no inciso II do art. $7^{\circ}$. Efetivamente, é impossível pretender que a testemunha ou vítima viva em clausura. No mínimo, seriam necessários deslocamentos seus para prestar depoimentos, ainda quando abdicasse de quaisquer outros, mesmo temporariamente. Todavia, talvez não lhe seja possível evitar esses deslocamentos. Nesse caso, de pouco valeria fosse protegida em sua residência. Se fosse o propósito de alguém intimidá-la ou mesmo ceifar-lhe a vida para que não viesse a depor, durante suas saídas da residência, tal seria possível." ${ }^{138}$

Conclui-se, pois, que a escolta e a segurança nos deslocamentos são de fundamental importância.

\subsubsection{Transferência de residência ou acomodação provisória em local compatível com a proteção}

Ao lado de outras medidas que se verificam nos incisos posteriores, a transferência da residência do protegido é a mais eficiente, na medida em que retira do local do risco a vítima ou testemunha e a coloca em segurança. É indispensável que o local seja desconhecido e isso acarreta ao órgão de execução encarregado da proteção uma responsabilidade muito grande, além de risco para as pessoas envolvidas.

No sistema de proteção empreendido atualmente, os órgãos de execução possuem funcionários especializados, mas que também se mantêm em anonimato, até mesmo

\footnotetext{
${ }^{138}$ DECOMAIN, Pedro Roberto. Proteção a testemunhas: redução de pena para o acusado que colabora com a investigação criminal. Revista do Ministério Público/Ministério Público do Estado do Rio de Janeiro, n. 12 , p. 162.
} 
porque estão se envolvendo com situações de alto risco. Em regra suas identidades são sigilosas e a atuação é recheada de medidas de segurança.

Como o financiamento do programa é público, todavia, o sistema sofre revezes enormes, como a prestação de contas e a verificação fiscal da utilização de valores, mas isso é assunto para ser tratado em outro item deste trabalho.

A transferência será, assim, feita de modo a assegurar ao protegido a inexistência de risco de ser encontrado, seja por aqueles que buscam atingi-lo para prejudicar seu depoimento, seja por seus amigos e familiares. É fundamental que o local de pouso seja absolutamente secreto, a fim de se garantir a eficiência da medida.

Isso traz a necessidade de algumas digressões. Em primeiro lugar, não se pode olvidar dos prejuízos que o protegido sofrerá em razão de ser retirado de seu lar, do convívio de familiares e amigos e colocado em situação de vida diferente daquela que sempre teve. A testemunha ou vítima, mutatis mutandis, viverá em situação bastante semelhante daquele que se quer punir com privação de liberdade.

Esta é, no entanto, uma daquelas situações da vida que são inevitáveis. Uma vez testemunha do fato investigado, ainda que isso possa acarretar um difícil encargo, a colaboração com a justiça é dever do cidadão e obrigação legal. Não há como evitar.

As regras de manutenção do programa também devem ser muito rígidas, pois o sigilo da nova vida do protegido não permite que velhos hábitos sejam mantidos. Com isso, muitos lugares por ele antes frequentado não serão mais acessíveis e eventuais vícios ilegais serão causas peremptórias de exclusão do programa.

É cediço que o protegido viciado no uso de entorpecentes será identificado com facilidade ao buscar fornecedores, notadamente pelo meio em que o comércio de drogas é efetuado. Além disso, há a possibilidade de o protegido ser, por exemplo, preso em flagrante, o que acarretará infinito prejuízo ao programa.

Eis aqui um dos problemas que exigem regras rígidas, pois o programa de proteção não pode evitar que outras ordens jurídicas sejam cumpridas e as consequências dos atos do protegido serão gravemente prejudiciais. Em vista disso, as regras de restrição verificadas no item 8.1.2 - "Critérios e requisitos para a inclusão" - deste trabalho. 


\title{
8.2.4 Preservação da identidade, imagem e dados pessoais
}

\author{
Dispõe o artigo 203 do Código de Processo Penal:
}

"Art. 203. A testemunha fará, sob palavra de honra, a promessa de dizer a verdade do que souber e lhe for perguntado, devendo declarar seu nome, sua idade, seu estado e sua residência, sua profissão, lugar onde exerce sua atividade, se é parente, e em que grau, de alguma das partes, ou quais suas relações com qualquer delas, e relatar o que souber, explicando sempre as razões de sua ciência ou circunstâncias pelas quais possa avaliar-se de sua credibilidade." (sem grifos no original)

Referido artigo faz menção específica à qualificação da testemunha, além de impor a descrição de nome, idade, estado, profissão e residência, e a exigência de dizer a verdade. Ora, a disposição de 1941 não previa a possibilidade de a testemunha ser ameaçada ou até mesmo a ousadia e agressividade de criminosos e organizações criminosas de hoje.

Com o artigo $7^{0}$, inciso IV, da Lei n⿳ํㅗ 9.807/99, o artigo 203 do Código de Processo Penal fica mitigado naquelas circunstâncias em que a testemunha ou vítima dependam de proteção estatal. Fica a questão: somente testemunhas inseridas no programa de proteção podem se valer da preservação de suas identidades? Creio que não.

$\mathrm{O}$ artigo $7^{\underline{0}}$, como já verificado, faz previsão geral a medidas e providências que concentram a proteção de testemunhas, na medida da necessidade. Então, é fácil verificar que se para a proteção da testemunha somente demandar a preservação de sua identidade, dispensável a inclusão em programa de proteção (que demandaria, v.g., transferência de residência).

No Estado de São Paulo vige o Provimento $32 / 2000^{139}$ da Corregedoria Geral da Justiça, pelo qual as vítimas ou testemunhas coagidas ou submetidas a grave ameaça, em

139 PROVIMENTO № 32/2000 - “O Desembargador Luís de Macedo, Corregedor Geral da Justiça do Estado de São Paulo, no uso de suas atribuições legais, Considerando o decidido no Processo CG 2573/2000, visando o aperfeiçoamento e eficácia da investigação policial e do processo criminal; Considerando que a segurança pública é dever do Estado, direito e responsabilidade de todos, exercida para a preservação da ordem pública e da incolumidade das pessoas; Considerando que a lei determina a adoção de medidas de proteção às vítimas e testemunhas, especialmente aquelas expostas a grave ameaça ou que estejam coagidas em razão de colaborarem com investigação ou processo criminal; Considerando que a lei restringe a publicidade dos atos processuais quando a defesa da intimidade ou o interesse social o exigirem, RESOLVE: Artigo $1^{\underline{0}}$ - Aplicam-se às disposições deste provimento aos inquéritos e processos em que os réus são acusados de crimes dentre aqueles discriminados no artigo $1^{\underline{0}}$, inciso III, da Lei Federal n⿳0 7.960, de 21 de 
assim desejando, não terão seus endereços e dados de qualificação lançados nos termos de seus depoimentos, cumprindo com o artigo $7^{\circ}$ da Lei $\mathrm{n}^{\mathrm{o}}$ 9.807/99.

Pelo Provimento 32/2000, os dados de qualificação das testemunhas são preservados, assim entendidos nos casos necessários para resguardar a segurança.

É necessário salientar, entretanto, que tais dados são importantes também para a defesa. Somente poderão ser preservados naquelas situações realmente necessárias. Não é sem motivo que o Código de Processo Penal determina a identificação das testemunhas.

Não se trata de simples direito da testemunha, ou seja, não é por capricho, por mera suposição de que o investigado queira vingança ou simplesmente por "se sentir melhor". É pertinente ressaltar que ao réu cabe o direito de assistir ao depoimento e que tudo seja feito

dezembro de 1989. Artigo $2^{\text {o }}$ - Quando vítimas ou testemunhas reclamarem de coação, ou grave ameaça, em decorrência de depoimentos que devam prestar ou tenham prestado, Juízes de Direito e Delegados de Polícia estão autorizados a proceder conforme dispõe o presente provimento. Artigo $3^{\circ}-$ As vítimas ou testemunhas coagidas ou submetidas a grave ameaça, em assim desejando, não terão quaisquer de seus endereços e dados de qualificação lançados nos termos de seus depoimentos. Aqueles ficarão anotados em impresso distinto, remetido pela Autoridade Policial ao Juiz competente juntamente com os autos do inquérito após edição do relatório. No Ofício de Justiça, será arquivada a comunicação em pasta própria, autuada com, no máximo, duzentas folhas, numeradas, sob responsabilidade do Escrivão. Artigo $4^{\mathrm{O}}-\mathrm{Na}$ capa do feito serão lançadas duas tarjas vermelhas, que identificam tratar-se de processo onde vítimas ou testemunhas postularam o sigilo de seus dados e endereços, consignando-se, ainda, os indicadores da pasta onde depositados os dados reservados. Artigo $5^{-}-\mathrm{O}$ acesso à pasta fica garantido ao Ministério Público e ao Defensor constituído ou nomeado nos autos, com controle de vistas, feito pelo Escrivão, declinando data. Artigo $6^{\circ} \mathrm{O}$ mandado de intimação de vítima ou testemunha, que reclame tais providências, será feito em separado, individualizado, de modo que os demais convocados para depoimentos não tenham acesso aos seus dados pessoais. Parágrafo único - Após cumprimento, apenas será juntada aos autos a correspondente certidão do Oficial de Justiça, sem identificação dos endereços, enquanto o original do mandado será destruído pelo Escrivão. Artigo $7^{0}-$ Ficam inseridas nas redações dos tópicos 15, 47 e 181 do capítulo V do tomo I das Normas de Serviço da Corregedoria Geral da Justiça os itens: I - '15. - DUAS TARJAS VERMELHAS: processo em que vítima ou testemunha pede para não ter identificados seus endereços e dados de qualificações’; II - '47.1 - Os mandados de intimação de vítimas ou testemunhas, quando estas derem conta de coação ou grave ameaça, após deferimento do Juiz, serão elaborados em separado, individualizados'; III - '47.2 - Uma vez cumpridos, apenas serão juntadas aos autos as certidões do Oficial de Justiça, nelas não sendo consignados os endereços e dados das pessoas procuradas. Os originais dos mandados serão destruídos pelo Escrivão'; IV - '181.1 - Os dados pessoais, em especial os endereços de vítimas e testemunhas, que tiverem reclamado de coação ou grave ameaça em decorrência de depoimentos que tenham prestado ou devam prestar no curso do inquérito ou do processo, após o deferimento da autoridade competente, devem ser anotados em separado, fora dos autos, arquivados sob a guarda do Escrivão do correspondente Ofício de Justiça, com acesso exclusivo aos Juízes de Direito, Promotores de Justiça e Advogados constituídos ou nomeados nos respectivos autos, com controle de vistas'. V - '181.2 - Na capa dos autos serão lançadas duas tarjas vermelhas, apontando tratar-se de processo onde vítimas ou testemunhas postularam o sigilo de seus endereços, bem como, consignando-se os dados identificadores da pasta onde foram depositados os dados reservados'. VI - '181.3 - As pastas terão, no máximo, duzentas folhas, serão numeradas e, após o encerramento, lacradas e arquivadas'. Artigo $8^{\circ}-\mathrm{O}$ presente provimento entrará em vigor na data de sua publicação. Publique-se. São Paulo, 24 de outubro de 2000. (a) Luís de Macedo - Corregedor Geral da Justiça." 
em sua presença, com transparência. Apenas em caráter excepcional far-se-á a preservação da identidade da testemunha nas situações previstas em lei ${ }^{140}$.

Cabe aqui uma discussão: existe diferença entre testemunha preservada e testemunha anônima?

A testemunha preservada conserva sua identificação e dados qualificativos em documentos sigilosos em poder do Juízo e que poderão ser objeto de verificação a qualquer tempo, como prevê o artigo $5^{\circ}$ do Provimento. Com isso, a testemunha não é anônima. Não se trata de uma testemunha que ninguém sabe o nome. A limitação é feita ao réu para a sua autodefesa somente, o que não indica nenhuma ilegalidade, como já se estudou neste trabalho.

Importante salientar que o defensor constituído ou nomeado, que está encarregado da defesa técnica - esta sim, indispensável e absoluta -, terá conhecimento do nome da testemunha.

Já houve entendimento propugnado no sentido de que a não divulgação do nome da testemunha ao acusado não lhe prejudica a defesa, pois no procedimento, a autodefesa aquela do réu em algumas fases do procedimento - é restrita, notadamente quando é retirado da sala de audiência para a colheita de prova oral. Assim sendo, a autodefesa é disponível desde o início do procedimento e não quando o juiz julga conveniente ${ }^{141}$.

Em sentido contrário, assemelhando as testemunhas não identificadas nos autos pelo Provimento 32/2000 com as testemunhas sem rosto do procedimento inquisitorial canônico, o Procurador Eduardo Depiné entende que a aplicação na primeira instância é equivocada e isso atinge, sim, o constitucional direito de defesa do acusado ${ }^{142}$.

\footnotetext{
${ }^{140}$ Veja-se Capítulo 3, que trata da presença física do réu em audiência.

141 BRUNO NETO, Mario Augusto. O direito em debate: breves considerações acerca do Provimento $\mathrm{n}^{\mathrm{o}}$ 32/00. Boletim Ibccrim, v. 13, n. 152, p. 14-15. Esclareceu ainda o autor: "A lei, portanto, não exige que se divulgue ao réu o nome da testemunha protegida, ao contrário, a supra-referida Lei $\mathrm{n}^{\mathrm{o}}$ 9.807/99 veda tal prática, sem que isto importe em qualquer cerceamento de autodefesa." (ibidem, loc. cit.).

${ }^{42}$ DEPINÉ FILHO, Davi Eduardo. O direito em debate: para que serve o Provimento n. 32/00. Boletim Ibccrim, v. 13, n. 152, p. 16-17, jul. 2005, citando, ainda, a obra A History of Continental Criminal Procedure (Augustus M. Kelley, New York, 1968, p. 92/93), segundo a qual, durante a evolução do processo inquisitorial canônico, em especialmente com os decretais dos Papas Bonifácio VIII, Pio IV e Paulo III, acabou-se por impedir ao acusado o conhecimento do nome das testemunhas que tivessem prestado, em sigilo, depoimentos que o incriminassem.
} 
A crítica do Procurador vem, inicialmente, pela absoluta falta de eficácia da medida, pois o defensor tem acesso às informações sigilosas e poderá, a qualquer tempo, passá-las ao réu, sendo-lhe imposto até pelos deveres advindos de seu mandato, não podendo sonegar informações.

Além disso, a testemunha, enganada, acredita que a defesa jamais terá conhecimento de seus dados e que estará protegida ${ }^{143}$.

Quanto à inconstitucionalidade, cita o procurador a competência exclusiva da União para legislar sobre o direito processual e isso só bastava para atingir o Provimento.

De fato, o Provimento data de época em que não havia nenhuma outra disposição legal que autorizasse a supressão de dados qualificativos das testemunhas. Todavia, com a promulgação da Lei $\mathrm{n}^{\mathrm{o}}$ 9.807/99, a questão fica resolvida, dada a legislação federal a respeito e que acolhe integralmente o procedimento do Provimento 32/2000.

Em relação à vitima, a Lei $n^{0}$ 11.690/08 trouxe providências específicas, alterando o artigo 155, do Código de Processo Penal, descrevendo os $\S \S 5^{\circ}$ e $6^{\circ}$.

"Se o juiz entender necessário, poderá encaminhar o ofendido para atendimento multidisciplinar, especialmente nas áreas psicossocial, de assistência jurídica e de saúde, a expensas do ofensor ou do Estado. O juiz tomará as providências necessárias à preservação da intimidade, vida privada, honra e imagem do ofendido, podendo, inclusive, determinar o segredo de justiça em relação aos dados, depoimentos e outras informações constantes dos autos a seu respeito para evitar sua exposição aos meios de comunicação."

\footnotetext{
${ }^{143}$ Percebe-se o engodo, pois o Estado não cumpre o que a lei lhe determina e oferece à testemunha amedrontada um placebo, apenas para que esta preste depoimento, acreditando na guarida do ineficaz aparato estatal. Nada mais cruel (DEPINÉ FILHO, Davi. O direito em debate: para que serve o Provimento n. 32/00. Boletim Ibccrim, v. 13, n. 152). Nesse sentido também a decisão do HC 376.330.3/5-00, Rel. Des. José Damião Pinheiro Machado Cogan, j. 18 de abril de 2002, cuja ementa oficial: Provimento no 32/2000 da Egrégia Corregedoria Geral de Justiça - Proteção de testemunhas ameaçadas ou com temor de represálias Permissão tão-somente de se omitir a qualificação e endereço nos autos, devendo ser remetidos em documento separado - Não cabimento de se omitir nome de testemunhas ou vítimas, para atendimento do princípio da ampla defesa - Inteligência do art. $3^{\frac{0}{}}$ do Provimento 32/2000 CGJ. Disponível em: http://esaj.tj.sp.gov.br/ cjsg/resultadoCompleta.do. Acesso em: 3 nov. 2009.
} 


\subsubsection{Ajuda financeira mensal para prover as despesas necessárias à subsistência individual ou familiar, no caso de a pessoa protegida estar impossibilitada de desenvolver trabalho regular ou de inexistência de qualquer fonte de custeio}

A ajuda financeira ao protegido também é primordial para a eficiência da medida, notadamente naqueles casos em que ocorre a transferência de residência. Ora, se o protegido é retirado de suas condições habituais e profissionais, não é de se exigir que ele possa, de imediato, conseguir outra colocação profissional, ainda que seja distante do distrito dos fatos. Não há medida de proteção segura e eficiente sem o custeio das despesas necessárias para a subsistência do protegido e também de sua família.

Evidente que o órgão encarregado da execução deve monitorar a utilização dessa ajuda financeira, até para que não haja desvio de verba pública.

Outra vez aqui deve ser salientada a fiscalização e administração de dinheiro público, considerando que o financiamento do programa é estatal.

Não se pode olvidar que o gasto público aqui tem natureza diferente de tudo aquilo que se verifica normalmente na administração pública. Neste ponto, o trabalho fará um pequeno apanhado de sistemas e princípios de administração pública.

A transparência tão exigida pelo direito administrativo não pode ser exigido na execução do programa de proteção à testemunha. O sigilo da utilização é necessário para que não haja prejuízo ao sigilo do local onde se encontra a testemunha.

A verificação de notas fiscais de aquisição de mercadorias e serviços, v.g., seriam com facilidade identificados os locais de pouso.

A situação requer, assim, tratamento especial, com sigilo máximo dos dados referentes aos protegidos. Porém, a legislação não faz essa previsão legal, o que significa a lacuna do ordenamento.

Convém lembrar do limite da ajuda financeira mensal, que será estabelecida pelo Conselho Deliberativo do respectivo programa no início de cada exercício financeiro (art. $7^{\text {o }}$, parágrafo único, Lei no ${ }^{9}$ 9.807/99). 


\subsubsection{Suspensão temporária das atividades funcionais, sem prejuízo dos respectivos vencimentos ou vantagens, quando servidor público}

Esta medida, por vias indiretas, atinge o mesmo financiamento público da subsistência do protegido, na medida em que a testemunha, servidora pública, deixa de trabalhar e continua recebendo seus vencimentos. Isso ocorrerá, em regra, nas situações de transferência de residência.

Uma dificuldade ocorre, qual seja, da comunicação ao superior hierárquico do servidor dos motivos de sua suspensão temporária, haja vista a necessidade de sigilo em relação a todas as circunstâncias que giram sobre a pessoa do protegido.

Decomain traz uma solução no sentido da impossibilidade de anotação em ficha funcional, ao menos durante o tempo em que durar a proteção estatal, estabelecendo ao superior hierárquico a obrigação legal de manutenção do sigilo ${ }^{144}$.

\subsubsection{Apoio e assistência social, médica e psicológica}

A lei ainda faz previsão para providência na qual o protegido seja amparado social e psicologicamente, o que possibilita à pessoa o enfrentamento da situação com menos prejuízos. É natural que a situação da testemunha ameaçada ou sob risco cause abalo psicológico e não é admissível que o Estado, ao amparar a testemunha ameaçada, não lhe proporcione tratamento psicológico adequado, até mesmo para que possa reingressar ao seio da sociedade após o período de risco.

\subsubsection{Sigilo em relação aos atos praticados em virtude da proteção concedida}

Sigilo é requisito para todas as demais providências, ainda que a lei o tenha destacado como uma providência isolada. Não é possível estabelecer a segurança ou a

\footnotetext{
${ }^{144}$ DECOMAIN, Pedro Roberto. Proteção a testemunhas: redução de pena para o acusado que colabora com a investigação criminal. Revista do Ministério Público/Ministério Público do Estado do Rio de Janeiro, n. 12, p. 165.
} 
transferência do protegido de sua residência e família se não houver o correspondente sigilo. Como, aliás, já salientado, a regra rigorosa do sigilo será, muitas vezes, impedimento de aceitação da testemunha à sua inclusão no programa.

\subsubsection{Apoio do órgão executor do programa para o cumprimento de obrigações civis e administrativas que exijam o comparecimento pessoal}

Como também já mencionado, o protegido, até sua inclusão no programa de proteção, estava envolvido e vinculado à sua vida social, profissional e familiar. Isso traz, por consequência, várias obrigações civis e administrativas.

Digamos que o protegido seja um pai acionado judicialmente para discussão de pensão alimentícia. Ora, isso demanda a contratação de advogado, comparecimento às audiências de conciliação e instrução, além de outras necessidades, em regra advindas da relação processual.

É inevitável que a realização de tais atos não pode ocorrer sem a contribuição do órgão executor do programa de proteção, até mesmo para garantir o sigilo dos dados e garantia de eficiência do próprio programa.

\subsubsection{Alteração do nome do protegido}

A lei também estabelece a providência de alteração do nome do protegido, mas evidente que será medida excepcional e somente em casos de extrema necessidade, dadas as consequências da providência.

De acordo com a lei de registros públicos, o prenome é definitivo, mas há três exceções, sendo a primeira de acordo com a vontade do titular, no primeiro ano após 
completar a maioridade ${ }^{145}$. A segunda exceção para substituir o prenome pelos "apelidos públicos notórios" ${ }^{\$ 146}$ e, por fim, a situação de nomes exóticos ou ridículos, que causem inevitável constrangimento ao titular ${ }^{147}$.

Agora, com a Lei $\mathrm{n}^{\mathrm{o}}$ 9.807/99, outra modalidade de alteração de registro aparece, sendo acrescentado o $\S 7^{\circ}$ ao artigo 57 e parágrafo único do artigo 58 , ambos da Lei $\mathrm{n}^{\mathrm{o}}$ 6.015/73:$$
\text { “(..) }
$$

§ 7ํㅡㄹ Quando a alteração de nome for concedida em razão de fundada coação ou ameaça decorrente de colaboração com a apuração de crime, o juiz competente determinará que haja a averbação no registro de origem de menção da existência de sentença concessiva da alteração, sem averbação do nome alterado, que somente poderá ser procedida mediante determinação posterior, que levará em consideração a cessação da coação ou ameaça que deu causa à alteração.

Art. 58. O prenome será definitivo, admitindo-se, todavia, a sua substituição por apelidos públicos notórios.

Parágrafo único: A substituição do prenome será ainda admitida em razão de fundada coação ou ameaça decorrente da colaboração com a apuração de crime, por determinação, em sentença, de juiz competente, ouvido o Ministério Público.”
\end{abstract}

A Lei $n^{0}$ 9.807/99 institui, assim, uma nova possibilidade de alteração do nome, incluindo o patronímico ou apelidos de família. Descreve o artigo 9ํㅡㄹ da lei: "Em casos excepcionais e considerando as características e gravidade da coação ou ameaça, poderá o conselho deliberativo encaminhar requerimento da pessoa protegida ao juiz competente para registros públicos objetivando a alteração do nome completo".

\footnotetext{
$145 \mathrm{O}$ interessado, no primeiro ano após ter atingido a maioridade civil, poderá, pessoalmente ou por procurador bastante, alterar o nome, desde que não prejudique os apelidos de família, averbando-se a alteração que será publicada pela imprensa (art. 56, Lei nº 6.015/73).

${ }^{146} \mathrm{O}$ prenome será definitivo, admitindo-se, todavia, a sua substituição por apelidos públicos notórios (art. 58, Lei n⿳0 6.015/73).

147 Qualquer alteração posterior de nome, somente por exceção e motivadamente após audiência do Ministério Público, será permitida por sentença do juiz a que estiver sujeito o registro, arquivando-se o mandado e publicando-se a alteração pela imprensa (art. 57, Lei $\mathrm{n}^{\mathrm{o}}$ 6.015/73).
} 
Inevitáveis as dificuldades que serão encontradas com a providência, dada a complexidade que existe na identificação civil e nos registros públicos, mormente nos dias de hoje, em que são vários os cadastros de nomes existentes - registro civil, registro de contribuintes, cadastro eleitoral, registro previdenciário, registro de motoristas habilitados e muitos outros, ainda na esfera particular, como cadastro de consumidores, devedores etc..

Imagina-se, então, que não seja simples a alteração do nome, pois não se trata de mais uma pessoa na imensidão de cadastros, mas a alteração de um deles. E o sigilo, dado o caráter público de tais cadastros, seria possível mantê-lo na alteração do nome quando da modificação de tantos cadastros?

Outra questão a ser observada é que, de início, a alteração deva ser somente do nome da pessoa protegida e não de seus pais e avós, significando a descontinuidade no patronímico de família. Já se pode antever as dificuldades que surgirão nas partilhas causa mortis.

A questão deve, enfim, ser melhor definida, pois a Lei $\mathrm{n}^{\mathrm{o}}$ 9.807/99 estabelece a providência e o procedimento para a alteração judicial, mas não resolve todas as questões aqui ventiladas.

Outra questão importante está prevista no $\S 1^{\underline{o}}$, parte final, que estabelece a alteração do nome precedida das providências necessárias ao resguardo de direitos de terceiros, dando-se a entender de que aquela providência não prejudicará o direito de terceiro.

A eventual dívida de Tício será, assim, mantida quando Tício alterar seu nome para Benvindo. Por óbvio isso prejudica o sigilo do programa e até a proteção propriamente dita, mas de fato o credor não pode ser prejudicado pela medida.

Entende-se, neste estudo, diante de todas essas dificuldades, que se a alteração do nome for causar problemas de outras ordens, não deve ser deferida, pois, por menor que seja o vazamento de informações com prejuízo ao sigilo, todo o programa será prejudicado.

A respeito da questão da eficácia da medida, manifesta-se Decomain: 
"Relembre-se que a alteração do nome tem, aqui, um nítido cunho de medida protetiva. Se não restar evidenciada a alteração do nome como providência para garantir efetiva proteção da vítima ou testemunha contra sua localização pelos que teriam interesse em coagi-la ou evitar seu depoimento, até mesmo através de providências mais drásticas, a alteração é de ser indeferida" ${ }^{148}$.

Pelo procedimento estabelecido, o pedido deve ser efetuado pela pessoa do protegido ao Conselho Deliberativo e este encaminha ao juiz competente. Ou, então, o pedido poderá ser efetuado diretamente pelo protegido ao juiz competente, mas, nesse caso, o Conselho Deliberativo deve ser consultado, pois a previsão legal é no sentido da providência como medida acautelatória de proteção e somente o Conselho Deliberativo pode decidir por sua inclusão no programa.

É cediço que essa providência nunca virá isolada de outras medidas acautelatórias, de modo que a tendência é a de partir do Conselho Deliberativo o pedido para alteração de nome.

Em Juízo, qual o procedimento de alteração a ser seguido? Via judicial ou via administrativa, conforme faz previsão a Lei de Registros Públicos? Para isso, descreve o dispositivo legal: "O requerimento será sempre fundamentado e o juiz ouvirá previamente o Ministério Público, determinando, em seguida, que o procedimento tenha rito sumaríssimo e corra em segredo de justiça” (art. 9ํㅗ $\S 2^{\underline{0}}$, Lei no $9.807 / 99$ ).

A alteração do nome poderá também alcançar as outras pessoas que também são incluídas no programa em vista da proximidade com a testemunha ou vítima ameaçada, inclusive filhos menores (art. $9^{\underline{o}}, \S 1^{\underline{0}}$ ).

Com a sentença, o juiz determinará as seguintes providências:

“§ $3^{0}$ - Concedida a alteração pretendida, o juiz determinará na sentença, observando o sigilo indispensável à proteção do interessado:

I - a averbação no registro original de nascimento da menção de que houve alteração de nome completo em conformidade com o estabelecido

\footnotetext{
${ }^{148}$ DECOMAIN, Pedro Roberto. Proteção a testemunhas: redução de pena para o acusado que colabora com a investigação criminal. Revista do Ministério Público/Ministério Público do Estado do Rio de Janeiro, n. 12, p. 171.
} 
nesta Lei, com expressa referência à sentença autorizatória e ao juiz que exarou e sem a aposição do nome alterado;

II - a determinação aos órgãos competentes para o fornecimento dos documentos decorrentes da alteração;

III - a remessa da sentença ao órgão nacional competente para o registro único de identificação civil, cujo procedimento obedecerá às necessárias restrições de sigilo."

Aqui surgem aquelas dificuldades mencionadas inicialmente a respeito do registro da alteração do nome. São vários os cadastros de nomes existentes (registro civil, registro de contribuintes, cadastro eleitoral, registro previdenciário, registro de motoristas habilitados e muitos outros, ainda na esfera particular, como cadastro de consumidores, devedores etc.). E o sigilo, seria possível manter o segredo da alteração do nome quando da modificação?

Decomain traz algumas soluções:

“O $\S 3^{\circ}$ do artigo disciplina as providências que deverão ser tomadas, na órbita do registro público, uma vez deferido o pedido de alteração de nome. A primeira delas, constante do inciso I daquele parágrafo, diz com a averbação da alteração do nome à margem do registro de nascimento da testemunha ou vítima. Diz a parte final do inciso que não haverá menção ao nome alterado. Ora, se o caso é de simples averbação da sentença, a referência ao nome seria inevitável, eis que o nome original da testemunha ou vítima continuaria figurando no registro. $\mathrm{O}$ que o inciso parece ordenar é mais do que simples averbação. Ordena a modificação do assento de nascimento da pessoa, no que diz respeito ao seu nome, averbando-se ainda à margem do assento, que esta modificação ocorreu por força da sentença proferida no pedido de alteração, com base na Lei no 9.807/99. A averbação indicará as razões que a motivaram, com referência à lei, ao nome do juiz que a ordenou e ao número do processo e vara judicial onde tramitou, por óbvio. Mas o nome original da pessoa, este não deverá continuar figurando no registro. Isso é o que lei pretende. E com tal providência procura resguardar, ainda mais, a identidade da 
testemunha ou vítima cujo nome tenha sido alterado para a sua própria proteção" ${ }^{149}$.

A medida nunca poderá ser implementada se não houver providências comezinhas como as de alteração do registro civil e este seria um ponto fraco, em vista da possibilidade de qualquer pessoa poder ter acesso ao assento de nascimento onde foi averbada a alteração do nome.

Como fazer, então, quando alguém pedir uma certidão de nascimento de Tício?

A solução talvez fosse criar uma nova figura jurídica de morte civil, com a declaração de óbito da pessoa do protegido, com novo registro de uma nova pessoa, resguardando-se a possibilidade de direito de terceiro. Somente nessa hipótese é que todas as dificuldades mencionadas seriam afastadas.

Todavia, com o intuito de minimizar essas fraquezas, a própria Lei $\mathrm{n}^{\mathrm{o}}$ 9.807/99 fez previsão à impossibilidade de se expedir certidão de registro público.

Prevê o artigo 16 da Lei de Registros Públicos que os oficiais e encarregados dos serviços registrários são obrigados a fornecer às partes as informações solicitadas e o artigo 17 determina a publicidade absoluta, pois "qualquer pessoa pode requerer certidão do registro sem informar ao oficial ou ao funcionário o motivo ou interesse do pedido”.

A nova descrição, entretanto, do artigo 18, dada pela Lei $n^{0} 9.807 / 99$, impede o fornecimento de certidão sem "despacho judicial", da seguinte forma: "Ressalvado o disposto nos arts. 45, 57, $\S 7^{\circ}$, e 95 , parágrafo único, a certidão será lavrada independentemente de despacho judicial, devendo mencionar o livro de registro ou o documento arquivado no cartório".

Isso parece mitigar as possibilidades de vazamento da informação, sendo indevida a expedição daquela certidão de nascimento sem anuência judicial. Talvez acarrete uma

\footnotetext{
${ }^{149}$ DECOMAIN, Pedro Roberto. Proteção a testemunhas: redução de pena para o acusado que colabora com a investigação criminal. Revista do Ministério Público/Ministério Público do Estado do Rio de Janeiro, n. 12, p. 174.
} 
celeuma no âmbito constitucional, dado o direito de petição e direito de obtenção de informações e certidões públicas pela publicidade do registro ${ }^{150}$.

A obtenção da certidão, no entanto, não será indeferida quando requerida com legitimidade, cumprindo, aliás, com a determinação constitucional. Sobre a questão afirmou Decomain:

"Em tema de certidões relativas ao registro de nascimento da pessoa cujo nome tenha sido alterado em proteção de sua identidade como testemunha ou vítima, o art. 18 da Lei no 9.807/99 determina que estas (certidões) somente podem ser expedidas por ordem judicial. É inerente aos registros públicos, exatamente porque são públicos, que certidões do que neles se acha contido devam ser expedidas a requerimento de qualquer interessado, sem que este necessite justificar por que necessita da certidão. Essa a regra do art. 18 da Lei dos Registros Públicos. Aquele artigo, todavia, contém exceções. Uma delas, introduzida exatamente pela Lei $\mathrm{n}^{\mathrm{o}}$ 9.807/99, é a de haver ocorrido, no registro de nascimento, alteração do nome de vítima ou testemunha como providência para sua proteção. A nova redação que o art. 18 da Lei dos Registros Públicos recebeu da Lei $n^{0}$ 9.807/99 faz referência ao § $7^{\underline{0}}$, do art. 57, também da Lei dos Registros Públicos. Esse parágrafo, a seu turno, foi inserido naquela lei pelo art. 16 da Lei $\mathrm{n}^{\mathbf{0}} 9.807 / 99$ e diz que trata da averbação da alteração de nome no registro de nascimento, para proteção de vítimas e testemunhas. Desta sorte, certidões do registro de nascimento da pessoa cujo nome tenha sido alterado para sua proteção como testemunha ou vítima, posteriores à averbação da alteração, somente poderão ser expedidas mediante determinação judicial ${ }^{\text {"151 }}$.

Por fim, prevê o artigo da lei:

\footnotetext{
${ }^{150}$ São a todos assegurados, independentemente do pagamento de taxas: a) o direito de petição aos Poderes Públicos em defesa de direitos ou contra ilegalidade ou abuso de poder; b) a obtenção de certidões em repartições públicas, para defesa de direitos e esclarecimento de situações de interesse pessoal (art. 5º XXXIV, CF).

${ }^{151}$ DECOMAIN, Pedro Roberto. Proteção a testemunhas: redução de pena para o acusado que colabora com a investigação criminal. Revista do Ministério Público/Ministério Público do Estado do Rio de Janeiro, n. 12 , p. 174/175.
} 
"§ $4^{0}-\mathrm{O}$ conselho deliberativo, resguardado o sigilo das informações, manterá controle sobre a localização do protegido cujo nome tenha sido alterado.

$\S 5^{0}$ - Cessada a coação ou ameaça que deu causa à alteração, ficará facultado ao protegido solicitar ao juiz competente o retorno à situação anterior, com a alteração para o nome original, em petição que será encaminhada pelo conselho deliberativo e terá manifestação prévia do Ministério Público.”

O protegido poderá cancelar a alteração de seu nome após o período de ameaça ou constrangimento, voltando a usar seu nome anterior.

\subsection{Programas de proteção no direito estrangeiro}

\subsubsection{Introdução}

O Brasil engatinha na proteção de suas vítimas e testemunhas, pois outros países como Estados Unidos e Itália já adotam o sistema de proteção há mais tempo.

Saliente-se a importância de se examinar os programas de proteção no mundo, como forma de melhor desenvolvimento do programa no País, além da possibilidade de se firmarem acordos para cooperação internacional.

É, no entanto, impossível a verificação dos programas em todos os países. Em razão disso, essa pesquisa será restrita aos principais países da Europa, mais Estados Unidos e dois países da América do Sul - Argentina e Colômbia. 


\subsubsection{Estados Unidos}

Nos Estados Unidos o sistema já funciona desde o ano de 1960, muito embora de forma diferente em relação ao formato atual, o qual passou, a partir de 1971, a ser implementado e regularmente são fornecidas novas identidades e documentos ao protegido, e, evidente, em segredo. Além disso, o programa conta com a proteção de uma polícia especial. Trata-se da U.S. Marshals Service, com estrutura que conta com orçamento de US\$ 50 milhões por ano. É tão sigilosa que nem mesmo o Congresso Nacional pode examiná-lo, como comenta Luiz Flávio Gomes ${ }^{152}$.

Sobre o Programa de Segurança de Testemunhas dos Estados Unidos, explica Victor Stone o funcionamento em documento fornecido em simpósio internacional ${ }^{153}$. O

${ }^{152}$ GOMES, Luiz Flávio. Lei de proteção a vítimas e testemunhas: primeiras considerações. Repertório IOB Jurisprudência, n. 18/99, p. 436.

153 4 $4^{\mathrm{O}}$ Simpósio Internacional dos Programas de Proteção a Vítimas e Testemunhas, de setembro de 2009 , Praia do Forte, Bahia. Algumas informações são sigilosas, mas o palestrante pontifica nos seguintes tópicos: “A. Goal: U.S. witness security actions should result in high profile prosecutions in order to publicly justify: 1. the appropriation and expenditure of significant public funds (well beyond what needy law abiding citizens receive); 2. the risk of future crimes to the public (and the risk to the careers of public officials) from hiding serious felon-witnesses (collaborators who are rarely rehabilitated) in plain view in an unsuspecting community, without bodyguards; 3 and shortening those serious felon-witnesses long sentences to gain cooperation, if they are still in prision. B. Program Requirements: 1. In a case of national significance (against an important high profile crime figure); 2. provide otherwise unavailable public testimony (because this is a costly tool of 'last resort'); 3. almost always from a serious criminal collaborator who can incriminate a gang leader but whom we predict will not, as a result of relocation or a shortened sentence, create an unacceptable danger to the community if released earlier than otherwise likely; 4. and who (along with other persons close to the witness) by an objective assessment, faces the risk of death from a retaliatory contract murder. C. Other concerns: 1 . Be vigilant and structure the program to defeat retaliation and program penetration from defendants, other similar gangs, and unstable persons in order to; 2 . maintain the crucial reputation of the program as 'safe harbor', or no witness will enter it. 3. Our program is very selective and unpleasant. A new start and identify amounts to total exile by choice. It is not normally appropriate for appealing to threatened government officials or bystander-victims, since it is designed as a law enforcement tool and not as a humanitarian program. D. Government infrastructure essential to our program: 1. trusted adequately paid staff and non-disclosure laws protecting de confidentiality of de the program's data (e.g. from corruption, organized crime, and political manipulation); 2. stable and substantial funding (in U.S., roughly $\$ 150,000$ per witness expended in first two years, not including program overhead expenses for perhaps 10 dedicated government personnel for 10 years); 3. the capacity and political will to initiate high profile prosecutions (and keeping those who would turn a blind eye to such cases from being able to veto program participation of key witness); 4. a domestic criminal procedure system where convictions can rely primarily upon a guilty person's testimony (note: the use of uncorroborated anonymous testimony rarely carries dispositive evidentiary weight. See, Euro Conv. Hum. Rights, Art. 6, para's 1\&3(d)); 5. secure prision and community relocation housing at home or abroad (plus foreign visas and work papers for witness, if the domestic population is less than 5 million); 6. a legal system that provides for both long sentences for supervisory criminals and incremental grants of leniency to induce witness to participate. Complete immunity works poorly since some such witnesses start to 'loose their memory' and jurors question whether they have been 'bribed' to lie; 7. criminal investigation and prosecution of any leak of program data or threats to a witness; 8. a narrowly focused program that is not responsible to perform unrelated responsibilities that could be performed by other government units (i.e. assistance to victims) because other public responsibilities both consume and expose the limited covert program personnel and assets". 
programa atende atualmente a quase dez mil pessoas ${ }^{154}$, sendo, sem dúvida, o maior programa de proteção de testemunhas, vítimas e réus colaboradores de que se tem notícia.

No mesmo simpósio, ainda outras informações foram fornecidas do programa norte-americano. Karine Moreno-Taxman ${ }^{155}$, que exerce um cargo no Ministério Público, refere-se aos casos de crime praticados por "gangues" utilizando o programa de proteção a vítimas e testemunhas (Prosecuting Gang Cases and Utilizing Witness Security Program). Explica a Promotora que 67\% dos novos casos que ingressam no programa são originários de crimes praticados pelas gangues, em razão da progressiva violência e agressividade praticada. Os protegidos são, em regra, informantes da polícia, membros de gangues rivais, traficantes rivais, namoradas ou esposas ou as "ex" e, também, pessoas da comunidade. Relata que o programa americano faz uma avaliação muito criteriosa das informações trazidas pela testemunha a ser protegida, pois a irrelevância de seu depoimento faz desaparecer o interesse do estado e a proteção pode não ocorrer. Não interessa a investigação custosa somente para condenação de "soldados". O programa tem financiamento para "resultados favoráveis" e proteger membros de gangues deve "valer a pena".

Os promotores, por sua vez, avaliam medidas alternativas, até mesmo poupando a testemunha de ser ouvida na corte, com a investigação sobre os fatos por ela trazidos. Ocorre que, em diversas situações, as informações trazidas pela testemunha são tão eficazes no sentido de se alcançar a condenação criminal de uma organização inteira, que sua vida será prejudicada em demasiado. Nesses casos, então, será possível poupar aquela testemunha, dado que será por demais visada, mesmo após o fim do processo.

É preciso sempre pensar na efetividade, buscando também ressocializar os membros das gangues que querem sair e para isso se servem do programa com oferta de seus depoimentos. Muitos, no entanto, não conseguem ter outra vida. Em razão disso, o programa recebe maciço ataque das gangues, que não querem perder seus "soldados", que sofrem ameaças quando querem deixar a vida de crimes.

\footnotetext{
${ }^{154}$ Informações do $4^{\text {o }}$ Simpósio Internacional dos Programas de Proteção a Vítimas e Testemunhas, de setembro de 2009, Praia do Forte, Bahia. Os autores Fábio Ramazzini Bechara e Luis Fernando de Moraes Manzano informam que se trata mais de pessoas arrependidas (95\%), sendo somente 5\% de testemunhas propriamente ditas (Crime organizado e terrorismo nos Estados Unidos da América. In: FERNANDES, Antonio Scarance; ALMEIDA, José Raul Gavião de; MORAES, Maurício Zanoide (Org.). Crime organizado - aspectos processuais. São Paulo: RT, 2009. p. 166).

${ }^{155}$ Resident Legal Advisor Brazil, U.S. Department of Justice, Office of Overseas Prosecutorial, Assistance and Training (OPDAT).
} 
Vários problemas são relatados pelos profissionais americanos do serviço de proteção e tudo depende muito da boa vontade dos servidores, criatividade na condução de cada caso e, em especial, ter em mente que não existem fórmulas mágicas (no magic pill exits).

Nos Estados Unidos, outros programas de proteção também são utilizados, assim como no Brasil, como os casos de proteção de adolescentes ameaçados, defensores de direitos difusos ou coletivos.

Nos Estados Unidos, ainda, o programa de proteção é conhecido como $U . S$. Marshals Service e está ligado ao Department of Justice, além de também se preocupar com a segurança nos tribunais, pois é o local onde a testemunha preservada prestará seu depoimento e onde certamente poderá ser encontrada. Também em palestra do Simpósio Internacional, o Inspetor-chefe Thomas Galgon explica o objetivo do programa americano:

"Entender que a segurança da testemunha é realizada através de uma abordagem significativa e abrangente da segurança dos tribunais e sistema judicial. Os tribunais são um dos pontos mais críticos no processo e para que a proteção seja eficaz, as testemunhas, juízes e promotores devem sentir-se seguros no tribunal."

\subsubsection{Argentina}

$\mathrm{Na}$ Argentina, no âmbito nacional, as medidas de proteção a testemunhas e acusados estão previstas na legislação ordinária, desde disposições mais simples, no Código de Processo Penal, até a edição de uma legislação específica para essa finalidade, a Lei $\mathrm{n}^{\mathrm{o}}$ 25.764, aprovada em 2003 e atualmente em vigor.

Como antecedentes legislativos da Lei $\mathrm{n}^{\mathrm{o}}$ 25.764/03, que dispôs sobre o assunto de modo pormenorizado, interessante destacar o já mencionado Código de Processo Penal (Lei $\mathrm{n}^{\mathrm{o}} 23.984$ de $1991^{156}$ ) que, em seu art. 79, prevê, ainda que de modo superficial, o

\footnotetext{
${ }^{156}$ Disponível em: http://www.infoleg.gov.ar/infolegInternet/buscarNormas.do. Acesso em: 7 maio 2007.
} 
direito das testemunhas e vítimas de receber tratamento digno das autoridades e proteção à integridade física e moral, própria e de seus familiares ${ }^{157}$.

Em 1995, a Lei $\mathrm{n}^{\mathrm{o}} 24.424^{158}$, dentre inúmeras alterações realizadas na Lei $\mathrm{n}^{\mathrm{o}}$ 23.737/89 ${ }^{159}$ (Combate ao Tráfico de Entorpecentes), incluiu o “Art. 33 Bis”, o qual inseriu no ordenamento jurídico a possibilidade, não apenas da testemunha, mas também do acusado, de receber medidas como mudança de domicílio, de identidade e até mesmo o temporário recebimento de quantia em dinheiro necessária para o próprio sustento durante o período de submissão às medidas ${ }^{160}$. A necessidade de tais medidas deveria ser analisada pelo Poder Judiciário e a execução, concretizada pelo Poder Executivo, por meio do Ministério da Justiça da Nação.

Apesar de a alteração legislativa e consequente previsão legal das medidas ter ocorrido em 1995, apenas em 1998, transcorridos três anos ${ }^{161}$, o Poder Executivo editou o Decreto $\mathrm{n}^{\mathrm{o}}$ 262/98 ${ }^{162}$ regulamentando o “Art. 33 Bis" da Lei $\mathrm{n}^{\mathrm{o}} 23.737$ e criando a Oficina de Proteção a Testemunhas e Acusados, sob a coordenação do Ministério da Justiça e apoio de outros Ministérios, em especial do Trabalho e Segurança Social.

${ }^{157}$ Código de Processo Penal Nacional: "Derechos de la víctima y el testigo

Art. 79 - Desde el inicio de un proceso penal hasta su finalización, el Estado nacional garantizará a las víctimas de un delito y a los testigos convocados a la causa por un órgano judicial el pleno respeto de los siguientes derechos:

a) A recibir un trato digno y respetuoso por parte de las autoridades competentes;

b) Al sufragio de los gastos de traslado al lugar donde la autoridad competente designe;

c) A la protección de la integridad física y moral, inclusive de su familia;

d) A ser informado sobre los resultados del acto procesal en el que ha participado;

e) Cuando se tratare de persona mayor de setenta (70) años, mujer embarazada o enfermo grave a cumplir el acto procesal en el lugar de su residencia; tal circunstancia deberá ser comunicada a la autoridad competente con la debida anticipación."

${ }^{158}$ Disponível em: http://www.infoleg.gov.ar/infolegInternet/verNorma.do?id=800. Acesso em: 7 maio 2007.

${ }^{159}$ Disponível em: http://www.infoleg.gov.ar/infolegInternet/buscarNormas.do. Acesso em: 7 maio 2007.

160 “Art. 33 Bis. - Cuando las circunstancias del caso hicieren presumir fundadamente un peligro cierto para la vida o la integridad física de un testigo o de un imputado que hubiese colaborado con la investigación, el tribunal deberá disponer las medidas especiales de protección que resulten adecuadas.

Están podrán incluso consistir en la sustitución de la identidad del testigo o imputado, y en la provisión de los recursos económicos indispensables para el cambio de domicilio y de ocupación, si fuesen necesarias. La gestión que corresponda quedará a cargo del Ministerio de Justicia de la Nación." (Artículo incorporado por art. 12 de la Ley № $\mathbf{2 4 . 4 2 4}$ B.O. 9/1/1995)

${ }^{161}$ CLARIN, 19 de março de 1998. Darán nueva identidad, casa y trabajo a testigos clave en casos de drogas. Disponível em: http://www.clarin.com/diario/1998/03/19/e-04001d.htm. Acesso em: 7 maio 2007.

162 Decreto 262/98: Créase la Oficina de Protección de Testigos e Imputados - Ley № 23.737 - en el ámbito de la Secretaría de Justicia. Bs. As., 9/3/98. Publicada en el Boletín Oficial del 18-mar-1998 Número: 28859. Disponível em: http://www.infoleg.gov.ar/infolegInternet/verNorma.do?id=49771. Acesso em: 7 maio 2007. 
No Decreto $\mathrm{n}^{\mathrm{o}}$ 262/98 foram definidas as autoridades competentes para recebimento e processamento da determinação do Poder Judiciário para submissão da pessoa à Oficina de Proteção. A determinação judicial deveria vir acompanhada da devida aceitação desta às condições da especial situação além da ciência de que o cometimento de novo delito acarretaria a exclusão do programa. O Decreto disciplinou ainda quais os órgãos responsáveis pela logística decorrente da eventual mudança de domicílio, identidade, realocação empregatícia e provisão de recursos financeiros. Deixou claro ainda que as medidas deveriam ser estendidas aos familiares próximos da pessoa caso houvesse necessidade.

Ocorre que, em virtude do Art. 33 Bis integrar uma legislação que trata do combate ao tráfico e consumo ilegal de entorpecentes, as medidas específicas de proteção a testemunhas e acusados, nos termos legais, só poderiam ser aplicadas no transcurso da persecução penal referente a tais delitos. Havia então uma lacuna legal no que tange a aplicação das medidas à apuração de outros crimes de relevância equiparada aos delitos de tráfico ilegal de entorpecentes, o que acarretaria, logicamente, questionamentos quanto à aplicação analógica de tais institutos.

Por fim, com o objetivo de ampliar o rol de delitos cuja apuração possibilitava a aplicação das medidas, além de aperfeiçoamento do próprio programa, em 2003, houve a promulgação da Lei $\mathrm{n}^{\mathrm{o}} 25.764^{163}$, específica para proteção de testemunhas e acusados.

A Lei n⿳0 25.764, no artigo 1ํㅡㄹ definiu a denominação do Programa como "Programa Nacional de Proteção a Testemunhas e Acusados", destinando-o para a execução das medidas que visam preservar a segurança daqueles que se encontrarem em uma situação de perigo à vida ou integridade física e que colaboraram de modo relevante e eficiente em uma investigação judicial de competência federal relativa aos crimes de extorsão ou constrangimento mediante sequestro (142 bis e 170 do Código Penal Argentino), relacionados ao tráfico de entorpecentes ou terrorismo. Dispôs ainda que outros casos que não se enquadrem nessas hipóteses, quando se tratar de crimes relacionados ao crime organizado ou violência institucional poderão ser incluídos pelo Ministro da Justiça, mediante requerimento da autoridade judicial.

163 Disponível em: http://www.infoleg.gov.ar/infolegInternet/verNorma.do?id=87581. Acesso em: 7 maio 2007. 
As medidas previstas no programa foram dispostas no Art. $5^{\circ}$ da Lei e consistem em:

- custódia policial pessoal ou domiciliar;

- hospedagem temporária em lugares reservados;

- mudança de domicílio;

- recebimento de meios econômicos para sustento e sobrevivência, dentro ou fora do país, pelo prazo máximo de seis meses;

- assistência para locomoção;

- assistência para reinserção no mercado de trabalho;

- recebimento de documentação com dados falsos que visem proteger a identidade da pessoa e de sua família.

São requisitos para a inclusão no programa:

- presunção de perigo em consequência do testemunho;

- interesse público em decorrência de crime grave;

- relevância das declarações da testemunha;

- viabilidade da aplicação das medidas de proteção;

- adaptação da pessoa às medidas.

A partir do funcionamento do Programa Nacional de Proteção a Testemunhas e Acusados, nos termos da Lei $\mathrm{n}^{\mathrm{o}}$ 25.764/03, há registros de que 68 pessoas foram submetidas ao Programa, encontrando-se, atualmente, 20 em trâmite. O Programa já colaborou com a investigação de casos importantes, a exemplo de denúncias de corrupção envolvendo senadores da República Argentina ${ }^{164}$.

164 EL PAÍS, 18 de outubro de 2006. Los sobornos en el Senado. Disponível em: http://www.pagina12.com.ar/diario/elpais/1-74686-2006-10-18.html. Acesso em: 7 maio 2007. 
Encontra-se em discussão no Poder Legislativo ${ }^{165}$ uma alteração na Lei $\mathrm{n}^{\mathrm{o}}$ 25.764/03 com o intuito de incluir, no rol dos delitos previstos no Art. $1^{\underline{o}}$, os crimes praticados contra os direitos humanos, em virtude das recentes ameaças recebidas por testemunhas e autoridades durante a persecução penal dos crimes cometidos durante o período ditatorial existente naquele país (1976-1983). De acordo com a atual redação da lei de Proteção a testemunhas e acusados, nada impede que essas pessoas sejam incluídas no Programa, todavia, os parlamentares desejam consignar tais crimes de forma expressa no artigo $1^{\underline{0}}$ de modo que não haja qualquer dúvida quanto à implementação das medidas para tais casos.

Ainda no que tange a propostas legislativas, há empenho do Ministério Público, por meio do Departamento de Assistência Integral a vítimas de crimes, em aprovar um projeto de 1 lei ${ }^{166}$ que, dentre outros direitos reservados às vítimas, prevê medidas semelhantes às já existentes no Programa Nacional de Proteção a Testemunhas e Acusados. Ressalte-se que nos termos do Programa não há qualquer vedação legal para a submissão de vítimas ao Programa, visando, tal projeto de lei, apenas a um destaque maior.

Por fim, no tocante ao plano legislativo, importa mencionar a Lei $\mathrm{n}^{\mathrm{o}} 25.765^{167}$, também promulgada em 2003 e que estabelece um Fundo Nacional de Recompensas financeiras para pessoas que, sem terem participado do delito, apresentem às autoridades, informações que permitam a libertação de pessoas ou prisão de infratores que participaram dos delitos de privação de liberdade qualificada e extorsão mediante sequestro, delitos também incluídos no rol da Lei de Proteção a Testemunhas e Acusados.

Como se vê, em termos legislativos, a República da Argentina possui disposições pormenorizadas e interessantes sobre o Programa Nacional de Proteção a Testemunhas e Acusados, sendo interessante acompanhar o aperfeiçoamento operacional do Programa, que existe desde 1998 para os delitos referentes ao tráfico ilícito de entorpecentes, mas que possui pouco mais de três anos com a abrangência para um número menor de delitos, o que talvez justifique uma quantidade ainda pequena de beneficiados pelas medidas.

\footnotetext{
${ }^{165}$ REUNION № 36 - 26a. Sesión ORDINARIA celebrada el 01/11/2006. Orden del día 1199. Disponível em: http://www1.hcdn.gov.ar/sesionesxml/item_param.asp?per=124\&r=36\&n=2. Acesso em: 7 maio 2007. ${ }^{166}$ Disponível em: http://www.mpf.gov.ar/Ofavi\%20pagina.htm. Acesso em: 7 maio 2007.

167 Disponível em: http://www.infoleg.gov.ar/infolegInternet/verNorma.do?id=87499. Acesso em: 7 maio 2007.
} 


\subsubsection{Colômbia}

A Colômbia, país dominado pelos cartéis das drogas e por guerrilhas armadas, possui legislação específica que estabelece instrumentos eficazes de manutenção do Estado Social e Democrático de Direito, garantindo a plenitude dos direitos e liberdade fundamentais reconhecidos pela Constituição e por Tratados Internacionais. Trata-se da Lei $\mathrm{n}^{\mathrm{o}}$ 418, de 26 de dezembro de 1997. Embora já modificada, ainda se mantém em sua estrutura fundamental ${ }^{168}$.

A segunda parte estabelece um capítulo especial para a proteção de vítimas e testemunhas, denominado "mecanismos para a eficácia da justiça - proteção a intervenientes em processo penal" (arts. 67-83).

O programa é dirigido pela Fiscalía General de la Nación, como é denominado o Ministério Público Federal, que tem, além da proteção de testemunhas e vítimas, também o desenvolvimento das investigações criminais e o oferecimento de acusação formal perante a autoridade judiciária. Coordena as funções da polícia, podendo representar por medidas que assegurem o comparecimento dos acusados em Juízo, conservação de provas, proteção da comunidade e eventual arquivamento de investigações ${ }^{169}$.

Interessante notar que o programa inclui outros interessados, como também servidores da própria Fiscalía. O programa denomina-se Programa de Protección a Testigos, Víctimas, Intervinientes en el Proceso y Funcionarios de la Fiscalía, dando-se a proteção também a familiares cujo parentesco atinja até o quarto grau, quando estes

\footnotetext{
${ }^{168}$ Aliás, a própria Constituição do país faz previsão ao programa de proteção de vítimas e testemunhas: "ARTICULO 250. Corresponde a la Fiscalía General de la Nación, de oficio o mediante denuncia o querella, investigar los delitos y acusar a los presuntos infractores ante los juzgados y tribunales competentes. Se exceptúan los delitos cometidos por miembros de la Fuerza Pública en servicio activo y en relación con el mismo servicio. Para tal efecto la Fiscalía General de la Nación deberá:

1. Asegurar la comparecencia de los presuntos infractores de la ley penal, adoptando las medidas de aseguramiento. Además, y si fuere del caso, tomar las necesarias para hacer efectivos el restablecimiento del derecho y la indemnización de los perjuicios ocasionados por el delito.

2. Calificar y declarar precluidas las investigaciones realizadas.

3. Dirigir y coordinar las funciones de policía judicial que en forma permanente cumplen la Policía Nacional y los demás organismos que señale la ley."

4. Velar por la protección de las víctimas, testigos e intervinientes en el proceso. (Disponível em: http://www.todoelderecho.com. Acesso em: 22 set. 2009).

${ }^{169}$ MACHADO, André Augusto Mendes; SOUZA, Diego Fajardo Maranha Leão de. O crime organizado na Colômbia. In: FERNANDES, Antonio Scarance; ALMEIDA, José Raul Gavião de; MORAES, Maurício Zanoide (Org.). Crime organizado - aspectos processuais, p. 101. Acrescentaram, ainda, os autores: "O Ministério Público, dirigido pelo Procurador-Geral da Nação, atua como órgão de controle, responsável pela guarda e promoção dos direitos humanos, a proteção do interesse público e a vigilância da conduta daqueles que desempenham funções públicas" (ibidem, loc. cit.).
} 
também se encontrem em risco de vida ou simplesmente perigo pela intervenção em processo penal. A Lei n 1.106/06 fez incluir na Lei nº 418 a definição de testemunha, para os efeitos de proteção:

\begin{abstract}
"Para efectos de protección por parte del programa, se entenderá por testigo la persona que ha tenido conocimiento de la comisión de un delito, o cualquier otra circunstancia que resulte relevante para demostrar la responsabilidad penal, que en concepto del funcionario judicial competente está en disposición de expresarlo durante la actuación procesal y de ello se derive un riesgo para su vida o integridad personal. Así mismo, estará a cargo del programa, los testigos de aquellos casos de violación a los derechos humanos e infracción al derecho internacional humanitario, independientemente de que no se haya iniciado el correspondiente proceso penal."
\end{abstract}

O programa, que também tem financiamento público, é organizado por uma agência denominada Oficina de Protección y Asistencia a Víctimas, Testigos y Funcionarios de la Fiscalía. A proteção se realiza por várias medidas como a proteção física, alteração de nome e de residência, além de "outras medidas temporárias ou permanentes" capazes de garantir a preservação da integridade física e moral do protegido, bem como de seu núcleo familiar ${ }^{170,171}$. A lei também possibilita a proteção mediante a retirada do protegido do território nacional, com a manutenção integral do protegido no exterior.

A alteração de identidade não implica isentar o protegido de qualquer obrigação legal ou responsabilidade no campo civil, penal, trabalhista etc., nem tampouco prejudicar terceiros (La aplicación de la presente ley no podrá menoscabar ninguno de los derechos contemplados en el artículo 29 de la Constitución para ninguna persona - art. 71).

\footnotetext{
${ }^{170}$ Artigo 69, Lei 418/97.

171 Artigo 71: "El Fiscal General podrá tomar en cualquier momento, cualquiera de las siguientes determinaciones: a) Ordenar el cambio de identidad de la persona que se someta al programa; En el caso de testigos, el cambio de identidad sólo se hará una vez termine el proceso, y siempre y cuando no se afecte el debido proceso; b) Con fundamento en la nueva identidad, ordenar a las autoridades, públicas o privadas, la expedición de documentos que reemplacen a los que ya posee el admitido al programa, tales como actas de registro civil, cédula de ciudadanía, pasaporte, libreta militar, certificado judicial y otros, sin que para su tramitación deban cumplirse los procedimientos ordinarios; c) Ordenar a los organismos de seguridad del Estado brindar la protección necesaria al admitido en el programa y a su núcleo familiar; d) Destinar para el admitido al programa, como domicilio permanente o transitorio cualquiera de las instalaciones que para el efecto considere adecuadas; e) Ordenar la expedición de títulos académicos por parte de entidades públicas o privadas para reemplazar a los originalmente otorgados, y f) Disponer la modificación de los rasgos físicos de la persona que pudieran permitir su identificación."
} 
O artigo 75 faz referência específica aos servidores públicos que colaborarem com “Organizações Armadas”, dadas as características particulares da Colômbia em relação aos grupos armados, que são reconhecidamente três: as Forças Armadas Revolucionárias da Colômbia (Farc), o Exército de Libertação Nacional (ELN) e as Autodefesas Unidas da Colômbia (AUC) ${ }^{172}$.

Aliás, até mesmo em razão dessa "guerra de duas frentes"173, há previsão legal para a proteção de testemunhas e vítimas fora do território nacional e acordos internacionais para implementação do programa.

\subsubsection{Europa}

Os programas de proteção na Europa têm sido executados com base em cooperação internacional, seja porque isso facilita a preservação das testemunhas, seja em razão da diminuta extensão territorial dos países. Como exemplo, na Sérvia, país recémindependente da antiga Iugoslávia, com território de apenas 88.361 quilômetros quadrados ${ }^{174}$, as dificuldades são imensas. Nesse caso, como explica Sasa Paunovic, do programa de proteção do Ministério do Interior daquele país, durante exposição em simpósio internacional, a proteção se dá somente pela cooperação internacional, ainda que seja em nível regional, o que inclui os países da Bulgária, Macedônia, Moldovia, Montenegro, Hersergovina.

São efetuados acordos internacionais em que se estabelece a troca de informações, a relocalização de pessoas, o transporte para depoimentos, com a proteção física de testemunhas e familiares. Também se encarrega da proteção física de juízes e promotores.

\footnotetext{
${ }^{172}$ MACHADO, André Augusto Mendes; SOUZA, Diego Fajardo Maranha Leão de. O crime organizado na Colômbia. In: FERNANDES, Antonio Scarance; ALMEIDA, José Raul Gavião de; MORAES, Maurício Zanoide (Org.). Crime organizado - aspectos processuais, p. 94.

${ }^{173}$ André Machado e Diego Souza asseveram que, além da guerra contra os narcotraficantes, também se depara o país com os grupos organizados guerrilheiros e paramilitares de direita, em que o conflito extrapola os limites do território e causa vítimas com a prática de extorsões e sequestros de estrangeiros (ibidem, loc. cit.).

${ }^{174}$ Disponível em: http://www.srbija.gov.rs/pages/article.php?id=6. Acesso em: 22 set. 2009.
} 
A cooperação entre vizinhos facilita em razão de várias vantagens, como a pequena distância, a mesma legislação, a língua, a cultura, os baixos custos e o "menor nível de stress", o que deve ser também uma preocupação do programa, dados os inevitáveis prejuízos psicológicos advindos da situação.

No Kosovo, país também de dimensões diminutas e com intensos conflitos étnicos e culturais, da mesma região da Sérvia, implantou o sistema de proteção de acordo com a cooperação internacional entre os seguintes países: Noruega, Suíça, Turquia e Estados Unidos da América. Formou-se, assim, a polícia internacional da União Europeia denominada European Union Rule of Law Mission (Eulex), com base no sistema de proteção das Nações Unidas (The Witness Security Unit), que envolve vinte países. Conduziu-se, dessa forma, a implantação do direito e da ordem.

No Kosovo, ao iniciar o processo de implantação do programa, foram encontrados 1.500 casos de crimes de guerra não resolvidos, 2.000 pessoas desaparecidas e 400 corpos não identificados ${ }^{175}$.

Existem, ademais, áreas de conflito em razão de pessoas de outras origens, que, por estarem estabelecidos, não querem deixar suas moradas.

Apresenta-se, a seguir, um breve resumo do programa de proteção nos seguintes países: Alemanha, Espanha, Bélgica, França, Inglaterra, Itália e Portugal.

\subsubsection{Alemanha}

No sistema processual alemão se verifica forte influência do sistema francês inquisitório, ainda que com os traços acusatórios da divisão de funções de persecução e julgamento aos dois responsáveis: Ministério Público e Magistratura ${ }^{176}$. Em razão disso, o

\footnotetext{
${ }^{175}$ MISCHKEWITZ, Andréas. Proteção de testemunhas no Kosovo. In: $4^{\circ}$ SIMPÓSIO INTERNACIONAL DOS PROGRAMAS DE PROTEÇÃO A VÍTIMAS E TESTEMUNHAS, Praia do Forte, Bahia, set. 2009. Mischkewitz é membro da polícia da Alemanha (Special Police Department Brandenburg), especialmente encarregado do programa de proteção no Kosovo por força de convenção internacional.

${ }^{176}$ JUY-BIRMANN, Rudolphe. O sistema alemão. In: DELMAS-MARTY, Mireille (Org.). Processos penais da Europa. Tradução de Fauzi Hassan Choukr e Ana Cláudia Ferigato Choukr. Rio de Janeiro: Lumen Juris, 2005. p. 22.
} 
juiz ouve as partes e recolhe os elementos necessários que possam influenciar em sua decisão e a oitiva de testemunha, vítima ou perito podem ser substituídos por documentos escritos. O Código de Processo também faz previsão à possibilidade da testemunha, ao ser ouvida, não declarar seus dados pessoais quando houver receio de represálias ( $§ 68$, $\mathrm{StPO})^{177}$. E a jurisprudência admite a possibilidade de a testemunha ser ouvida por um policial, que por sua vez será ouvido na audiência, em especial para proteção da identidade da testemunha (§ 251, II, StPO). A jurisprudência, aliás, vai além, possibilitando a oitiva do juiz que ouviu a testemunha anteriormente ${ }^{178}$.

\subsubsection{Espanha}

A Espanha também possui legislação própria para proteção de testemunhas, dado que o país do mesmo modo enfrenta o problema da criminalidade organizada, mormente em relação ao tráfico de entorpecentes, tráfico e exploração de seres humanos para fins laborais ou sexuais, tráfico de armas, roubo e tráfico ilegal de veículos, além de crimes econômicos ${ }^{179}$.

A Ley Orgánica $n^{0}$ 19, de 23 de dezembro de 1994, faz referência à proteção de testemunhas e "peritos" que intervenham em processo penal ${ }^{180}$, estabelecendo como requisito da proteção a existência de grave perigo. Presente o requisito, a critério do juiz competente, a proteção se estabelece estendendo, se for o caso, ao cônjuge, aos ascendentes, descendentes ou irmãos.

A proteção será determinada pelo juiz, preservando a identidade do protegido, seu domicílio, profissão e lugar de trabalho, sem prejuízo do direito de defesa, podendo

\footnotetext{
${ }^{177}$ JUY-BIRMANN, Rudolphe. O sistema alemão. In: DELMAS-MARTY, Mireille (Org.). Processos penais da Europa, p. 40.

${ }^{178}$ Ibidem, p. 41.

${ }^{179}$ COGAN, Marco Antonio Pinheiro Machado; JOSÉ, Maria Jamile. O crime organizado e terrorismo na Espanha. In: FERNANDES, Antonio Scarance, ALMEIDA, José Raul Gavião de; MORAES, Maurício Zanoide (Org.). Crime organizado - aspectos processuais, p. 128/129.

180 “Artículo 1. Las medidas de protección previstas en esta Ley son aplicables a quienes en calidad de testigos o peritos intervengan en procesos penales." Lei $n^{o}$ 19/94. Disponível em: http://www.noticias.juridicas.com. Acesso em: 28 set. 2009).
} 
igualmente estabelecer providências para proteger a identidade visual da testemunha no momento da tomada de declarações ${ }^{181}$.

O Código Penal faz previsão de dois tipos penais que prevêem pena para quem usa de intimidação ou violência contra quem seja denunciante ou simples testemunha, aproximando-se do crime de "coação no curso do processo" previsto no ordenamento jurídico brasileiro. Ainda assim, no entanto, a legislação espanhola é considerada deficiente pela União Europeia por ser incompleta e inadequada, não atendendo às recomendações mínimas do Conselho da Europa aos "colaboradores"182.

\subsubsection{Bélgica}

Assim como o modelo germânico, o sistema belga baseou-se drasticamente no sistema francês, mesmo porque as províncias belgas foram incorporadas pelas forças armadas francesas em 1795, o que determinou o cumprimento dos códigos napoleônicos e demais leis penais e processuais. O país foi, posteriormente, incorporado pela Holanda e, mesmo independente a partir de 1830, a legislação processual penal se manteve. Houve propostas para alteração, mas somente com as pressões do caso Dutroix ${ }^{183}$ é que o Código de Processo Penal ganhou a forma atual.

Em razão disso, o sistema belga se apresenta, na fase preliminar, chamada de autos de investigação, o sistema inquisitivo, absolutamente sigiloso, e os interessados somente podem ter vistas com autorização expressa do juiz de instrução. $\mathrm{Na}$ segunda fase, do

\footnotetext{
181 "Artículo 2. Apreciada la circunstancia prevista en el artículo anterior, el Juez instructor acordará motivadamente, de oficio o a instancia de parte, cuando lo estime necesario en atención al grado de riesgo o peligro, las medidas necesarias para preservar la identidad de los testigos y peritos, su domicilio, profesión y lugar de trabajo, sin perjuicio de la acción de contradicción que asiste a la defensa del procesado, pudiendo adoptar las siguientes decisiones: a. Que no consten en las diligencias que se practiquen su nombre, apellidos, domicilio, lugar de trabajo y profesión, ni cualquier otro dato que pudiera servir para la identificación de los mismos, pudiéndose utilizar para ésta un número o cualquier otra clave. b. Que comparezcan para la práctica de cualquier diligencia utilizando cualquier procedimiento que imposibilite su identificación visual normal. c. Que se fije como domicilio, a efectos de citaciones y notificaciones, la sede del órgano judicial interviniente, el cual las hará llegar reservadamente a su destinatario."

${ }^{182}$ COGAN, Marco Antonio Pinheiro Machado; JOSÉ, Maria Jamile. O crime organizado e terrorismo na Espanha. In: FERNANDES, Antonio Scarance, ALMEIDA, José Raul Gavião de; MORAES, Maurício Zanoide (Org.). Crime organizado - aspectos processuais, p. 148.

${ }^{183}$ Caso célebre envolvendo sequestro e morte de inúmeras crianças por pedófilos (PESQUIÉ, Brigitte. O sistema belga. In: DELMAS-MARTY, Mireille (Org.). Processos penais da Europa, p. 77-78).
} 
julgamento, o sistema é acusatório, com ampla defesa e contraditório dirigido pela Corte Criminal $^{184}$.

\subsubsection{França}

O processo penal na França tem contornos do sistema inquisitorial que foram a base dos sistemas processuais em muitos países da Europa. A constitucionalização e a internacionalização, todavia, foram fenômenos que auxiliaram a mudança do pensamento francês, tornando-o mais garantidor e democrático ${ }^{185}$.

No sistema francês, há nítida separação de funções, muito embora os representantes do Ministério Público e da magistratura saiam da mesma Escola Nacional de Magistratura. O Ministério Público é encarregado da persecução. A instrução dos casos penais é realizada pelo juiz de instrução e o julgamento, por um juiz monocrático ou colegiado, de acordo com a natureza da infração e, por fim, a execução de penas de responsabilidade do Ministério Público e juiz próprio ${ }^{186}$.

Os crimes mais graves são julgados pelo escabinado (cour d'assises) ${ }^{187}$, sendo investido de um poder discricionário em virtude do qual, em sua honra e consciência, toma as medidas que acredita úteis para descobrir a verdade, estabelecendo a ordem da oitiva de testemunhas, as perguntas que serão realizadas e, principalmente, a retirada do acusado do local do julgamento se assim for necessário para a oitiva da testemunha ${ }^{188}$.

O Código de Processo Penal possui capítulo próprio para regulamentar a proteção de testemunhas desde 2001, com a aprovação da Loi n. 2001-1062, de 15 novembro de 2001 - art. 57 JORF, de 16 de novembro de 2001. A última alteração ocorreu em maio de 2009, mas somente para reajustes do procedimento.

\footnotetext{
${ }^{184}$ PESQUIÉ, Brigitte. O sistema belga. In: DELMAS-MARTY, Mireille (Org.). Processos penais da Europa, p. 82.

${ }^{185}$ CAÇAPAVA, Elisa Pires da Cruz Reale; VILARES, Fernanda Regina. Crime organizado e terrorismo na França. In: FERNANDES, Antonio Scarance; ALMEIDA, José Raul Gavião de; MORAES, Maurício Zanoide (Org.). Crime organizado - aspectos processuais, p. 186.

${ }^{186}$ DERVIEUX, Valérie. O sistema francês. In: DELMAS-MARTY, Mireille (Org.). Processos penais da Europa, p. 167.

${ }^{187}$ Ibidem, p. 186.

${ }^{188}$ Ibidem, p. 187.
} 
O programa prevê, inicialmente, a possibilidade de resguardo de informações sobre o endereço da testemunha, a critério do juiz de instrução, ouvido o Procurador da República $^{189}$. A inclusão no programa depende da verificação da existência de perigo à integridade física da testemunha e de seus familiares. Em seus depoimentos, sua identidade permanece inacessível $^{190}$. Interessante notar que a legislação francesa estipula de forma expressa o direito de conhecimento da qualificação da testemunha em razão do direito de ampla defesa $^{191}$.

\subsubsection{Inglaterra}

O sistema inglês prescinde da existência de Código de Processo, valendo-se de leis esparsas, jurisprudência como fonte do direito e, evidentemente, da Carta Magna de 1215, do Bill of Rights de 1688 e, mais recentemente, do Ato sobre Direitos Humanos (Human Rights Acts) de $1988^{192}$.

A jurisprudência tem relevo especial em virtude da commom law. Em primeiro lugar porque muitas das regras estatutárias são aplicadas em conjunto com julgados das cortes de justiça e, depois, porque áreas completas do processo penal inglês são reguladas

\footnotetext{
${ }^{189}$ Art. 706-57 do Code de procédure pénale. Disponível em: http://www.legifrance.gouv.fr/affichCode.do; jsessionid=4287D6F73EDFA359C0530CA3147C9A58.tpdjo02v_3?idSectionTA=LEGISCTA00000613813 $3 \&$ cidTexte $=$ LEGITEXT000006071154\&dateTexte=20090929. Acesso em: 29 set. 2009.

190 "En cas de procédure portant sur un crime ou sur un délit puni d'au moins trois ans d'emprisonnement, lorsque l'audition d'une personne visée à l'article 706-57 est susceptible de mettre gravement en danger la vie ou l'intégrité physique de cette personne, des membres de sa famille ou de ses proches, le juge des libertés et de la détention, saisi par requête motivée du procureur de la République ou du juge d'instruction, peut, par décision motivée, autoriser que les déclarations de cette personne soient recueillies sans que son identitité apparaisse dans le dossier de la procédure. Cette décision n'est pas susceptible de recours, sous réserve des dispositions du deuxième alinéa de l'article 706-60. Le juge des libertés et de la détention peut décider de procéder lui-même à l'audition du témoin.

La décision du juge des libertés et de la détention, qui ne fait pas apparaître l'identité de la personne, est jointe au procès-verbal d'audition du témoin, sur lequel ne figure pas la signature de l'intéressé. L'identité et l'adresse de la personne sont inscrites dans un autre procès-verbal signé par l'intéressé, qui est versé dans un dossier distinct du dossier de la procédure, dans lequel figure également la requête prévue à l'alinéa précédent. L'identité et l'adresse de la personne sont inscrites sur un registre coté et paraphé, qui est ouvert à cet effet au tribunal de grande instance." (Art. 706-58. Disponível em: www. legifrance.gouv.fr. Acesso em: 22 set. 2009.)

191 "Les dispositions de l'article 706-58 ne sont pas applicables si, au regard des circonstances dans lesquelles l'infraction a été commise ou de la personnalité du témoin, la connaissance de l'identité de la personne est indispensable à l'exercice des droits de la défense." (Art. 706-60. Disponível em: www. legifrance.gouv.fr. Acesso em: 22 set. 2009.)

${ }^{192}$ SPENCER, J. R. O sistema inglês. In: DELMAS-MARTY, Mireille (Org.). Processos penais da Europa, p. 247.
} 
pela jurisprudência, como são exemplos a lei de abuso processual e grande parte das regras sobre prova ${ }^{193}$.

Existe uma peculiaridade no sistema britânico, o Crown Prosecution Service (CPS - Serviço de Persecução da Coroa). Não se trata do Ministério Público inglês; sua estrutura é muito diferente da de outros países da Europa e também do direito brasileiro. Também não é órgão de polícia e não inicia nenhuma investigação. Tão somente recebe as informações sobre a investigação efetuada pela polícia e efetua a acusação perante a Corte Criminal em procedimento sumário. A polícia e os órgãos de acusação possuem muito mais fundos que a defesa e, em função disso, a investigação é sempre muito bem realizada, com instrumentos e tecnologia ${ }^{194}$.

Sobre a prova, existem algumas regras especiais impostas pela legislação, mas que constituem detalhes não tão importantes, como é exemplo a proibição do depoimento de "ouvir dizer" ou a proibição de relato testemunhal escrito, o que faz do procedimento inglês oral em sua essência.

Interessante, entretanto, a regra sobre a oitiva do réu, que oferta seu depoimento pela sua vontade, mas se isso ocorrer, será considerado testemunha. Isso é, aliás, uma regra muito comum nos sistemas do common law. Em razão disso, o réu não pode utilizar-se do direito de silêncio contra sua a autoincriminação ${ }^{195}$.

Outra característica do sistema inglês é a possibilidade de negociação entre a defesa e acusação, chamada de plea-bargaining, em que o réu assume a culpa por um crime e, por vezes, terá outra acusação mais séria arquivada ${ }^{196}$.

A legislação própria de combate ao crime organizado (Serious Organised Crime Act 2005), legislação essa que cria a agência denominada Soca (The Serious Organised Crime Agency), com a finalidade de iniciar e desenvolver as investigações e procedimentos penais $^{197}$. Na verdade, essa lei disciplina as funções de coleta, armazenagem, análise e

\footnotetext{
${ }^{193}$ SPENCER, J. R. O sistema inglês. In: DELMAS-MARTY, Mireille (Org.). Processos penais da Europa, p. 249.

${ }^{194}$ Ibidem, p. 256-276.

195 Ibidem, p. 311.

${ }^{196}$ Ibidem, p. 333.

${ }^{197}$ São funções da agência: "preventing and detecting serious organised crime, and contributing to the reduction of such crime in other ways and to the mitigation of its consequences". (Disponível em: http:// www.opsi.gov.uk/acts/acts2005/ukpga_20050015_en_2\#pt1-ch1-pb2-11g2. Acesso em: 29 set. 2009.
} 
disseminação de informações relevantes à prevenção e persecução criminais não só do crime organizado, mas de todo e qualquer crime ${ }^{198}$.

A Serious Organised Crime Act 2005 também fez previsão para o programa de proteção de testemunhas ${ }^{199}$, em que estabeleceu a possibilidade de proteção para outras pessoas envolvidas na persecução criminal, como são os casos de quem cumpriu a disclosure notice ${ }^{200}$, a immunity notice ${ }^{201}$ ou de quem possui uma restricted use undertaking ${ }^{202}$ que ainda tenha efeitos.

Também podem se utilizar do programa de proteção os jurados, juízes, ainda que de tribunais internacionais, policiais, oficiais de imigração e membros das agências de investigação, bem como seus familiares que vivam na mesma casa, ou que mantenham relacionamento muito próximo ${ }^{203}$.

São os policiais da Serious Organised Crime Agency que executam o programa e que decidem as providências que devem ser tomadas para cumprir com esse objetivo, inclusive a troca de identidades ${ }^{204}$.

\footnotetext{
${ }^{198}$ PEREIRA, Fábio Franco; HÖHN JR., Ivo Anselmo. O combate ao crime organizado e ao terrorismo na Inglaterra. In: FERNANDES, Antonio Scarance; ALMEIDA, José Raul Gavião de; MORAES, Maurício Zanoide (Org.). Crime organizado - aspectos processuais, p. 211, nota 28.

${ }^{199}$ Capítulo 4, disponível em: http://www.opsi.gov.uk. Acesso em: 29 set. 2009.

${ }^{200}$ A disclosure notice é um documento entregue pessoalmente ou enviado pelo correio que obriga o indivíduo a responder às perguntas formuladas pelo órgão acusatório, produzir documentos ou prestar qualquer informação referente ao caso. Não é possível, sem motivo razoável, falhar em atender à disclosure notice, uma vez que, nesse caso, cometer-se-á um crime punível com até 51 semanas de prisão. Somente se aplica aos crimes de tráfico de drogas, lavagem de dinheiro, terrorismo e seu financiamento, tráfico de seres humanos e de armas, contrabando, crimes contra a propriedade intelectual, rufianismo, extorsão e crimes tributários (PEREIRA, Fábio Franco; HÖHN JR., Ivo Anselmo. O combate ao crime organizado e ao terrorismo na Inglaterra. In: FERNANDES, Antonio Scarance; ALMEIDA, José Raul Gavião de; MORAES, Maurício Zanoide (Org.). Crime organizado - aspectos processuais, p. 218).

${ }^{201}$ Immunity notice é o instrumento legal pelo qual é oferecido um benefício ao criminoso que quiser auxiliar nas investigações. É a imunidade de acusação com relação a crimes previamente estipulados, para os fins de investigação ou acusação (ibidem, p. 217).

${ }^{202}$ Restricted use undertaking é uma promessa formal de uso restrito que contenha uma garantia de que a afirmação prestada pelo colaborador não será usada contra ele como prova, exceto nas circunstâncias especificadas pela própria promessa (ibidem, loc. cit.).

${ }^{203}$ Ibidem, p. 222.

${ }^{204}$ Ibidem, loc. cit.
} 


\subsubsection{Itália}

$\mathrm{Na}$ Itália, o desenvolvimento da legislação estabeleceu um procedimento de instrução, caracterizado pela mistura do sistema acusatório e do sistema inquisitorial, resquício do código napoleônico que baseou a legislação italiana até o início do século XX.

Depois, a legislação processual passou por duas situações diversamente proporcionais: primeiro o Código de Processo liberal de 1913, eliminando os traços totalitários de outrora e, depois, em 1930, o Código fascista do Ministro Alfredo Rocco, sob o comando de Mussolini, marcado por fortes limitações das garantias fundamentais. Em 1988, então, surge o Código de Processo Penal hodiernamente em vigor, embora já bastante modificado ${ }^{205}$. O sistema italiano proporciona à defesa a possibilidade de investigação própria ${ }^{206}$.

O programa de proteção de testemunhas existe desde 1991, oportunidade em que foi criado o Serviço Central de Proteção, órgão ligado ao Ministério do Interior ${ }^{207}$.

O sistema proporciona proteção tanto a testemunhas quanto aos réus colaboradores, mas a legislação italiana diferencia as duas figuras, justamente para destacar e distinguir o réu colaborador como implicado na conduta e quem somente tem dever cívico de solidariedade, bem como vencer a omertà (lei do silêncio), oferecendo um instrumento de incentivo para que os criminosos se livrem das organizações criminosas ${ }^{208}$.

${ }^{205}$ PERRODET, Antoinette. O sistema italiano. In: DELMAS-MARTY, Mireille (Org.). Processos penais da Europa, p. 343.

${ }^{206}$ Uma lei própria de 2000 alterou o Código de Processo Penal para estabelecer as "regras concernentes à possibilidade de investigação pela defesa", estendendo os mesmos poderes de investigação também ao defensor, como entrevistar pessoas, entrar em lugares privados ou lugares nos quais o público não é normalmente permitido e poder buscar e examinar provas ou indícios. Pode também o defensor substabelecer a agentes autorizados privados e a consultores técnicos a realização dessas atividades (ibidem, p. 362).

207 "A maioria das pessoas protegidas são ex-mafiosos que decidiram colaborar com a justiça. Eles recebem garantias como anonimato para si e para suas famílias, mudança de nome, de cidade etc. O governo oferecelhes uma casa para morar, salário e ajuda para recomeçar a vida, com novo trabalho e escola para os filhos, tudo em troca de suas informações. O governo italiana gasta com este programa algo em torno de US\$100milhões por ano" (GOMES, Luiz Flávio. Lei de proteção a vítimas e testemunhas: primeiras considerações. Repertório IOB Jurisprudência, n. 18/99, p. 436). Também existem testemunhas, mas em número menor. Ao final da década de 1990, eram 1.100 colaboradores, para somente 56 testemunhas (VAGGIONE, Luiz Fernando; SILVEIRA, Rodrigo Mansour Magalhães da. O crime organizado na Itália e as medidas adotadas para o seu combate. In: FERNANDES, Antonio Scarance; ALMEIDA, José Raul Gavião de; MORAES, Maurício Zanoide (Org.). Crime organizado - aspectos processuais, p. 241).

${ }^{208}$ VAGGIONE, Luiz Fernando; SILVEIRA, Rodrigo Mansour Magalhães da. O crime organizado na Itália e as medidas adotadas para o seu combate. In: FERNANDES, Antonio Scarance; ALMEIDA, José Raul Gavião de; MORAES, Maurício Zanoide (Org.), op. cit., loc. cit. Os autores ainda destacam o regime diferenciado de proteção: características das declarações e dos delitos a que se referem; maior extensão das medidas especiais de proteção ao círculo de pessoas que têm relação com a testemunha; contribuições econômicas mais amplas, se comparadas com as dos colaboradores da justiça; exoneração de indicação dos 
Para o réu colaborador existe uma série de regras especiais, notadamente para garantir maior autenticidade e credibilidade de suas declarações, bem como para a sua proteção em relação à organização criminosa a que pertencia. Há também instrumentos de proteção de diversa intensidade:

- medidas especiais de caráter contingente e provisório;

- programa especial, com adoção de um novo projeto de vida.

A escolha de um ou outro programa depende da gravidade do perigo e dos atos de colaboração ${ }^{209}$.

O colaborador pode assumir uma das situações expostas pela legislação de proteção e colaboração:

- posição de indagado-imputado, nas circunstâncias de colaboração e informação sobre atos delituosos também por ele praticados;

- posição de indagado-imputado de delito conexo;

- posição de testemunha assistida, quando o imputado revela atos criminosos de seus companheiros de crime; e

- posição de testemunha, em relação aos delitos absolutamente desvinculados ${ }^{210}$.

bens que possui; e previsão de criação de Serviço Central de Proteção com seção destinada exclusivamente às testemunhas (VAGGIONE, Luiz Fernando; SILVEIRA, Rodrigo Mansour Magalhães da. O crime organizado na Itália e as medidas adotadas para o seu combate. In: FERNANDES, Antonio Scarance; ALMEIDA, José Raul Gavião de; MORAES, Maurício Zanoide (Org.). Crime organizado - aspectos processuais, p. 242).

${ }^{209}$ Ibidem, p. 243.

${ }^{210}$ Ibidem, p. 244. 


\subsubsection{Portugal}

O programa de proteção de testemunhas de Portugal existe desde 1999, com a edição da Lei nº 93, de 14 de julho de 1999, que regula a aplicação de medidas de proteção no processo penal ${ }^{211}$.

O programa é executado com a ocultação da testemunha, possibilitando à pessoa prestar seu depoimento sem mostrar sua imagem ou com a distorção da voz, de forma a evitar que seja reconhecida. Também é possível tomar o depoimento por teleconferência ou simplesmente ocultar os dados de qualificação da testemunha ou ainda o depoimento sob anonimato, presentes os requisitos legais ${ }^{212}$.

Até como forma de manter a proporcionalidade, no entanto, a legislação processual estabelece que nenhuma condenação deve ocorrer se estiver fundada exclusivamente em depoimentos ou declarações produzidas por testemunhas cuja identidade não tenha sido revelada $^{213}$. A questão é que a possibilidade de testemunha anônima é muito criticada não só pela doutrina em Portugal, mas também na União Europeia ${ }^{214}$.

A proteção, nos moldes da legislação portuguesa, é feita por várias medidas, v.g., indicação de residência diferente, transporte em viatura especial, compartimento vigiado e protegido nas instalações judiciárias e policiais, proteção policial, estendida a familiares e pessoas próximas $^{215}$.

Esses constituem, em síntese, alguns dos programas pesquisados e que demonstram a utilização do sistema de proteção nos principais polos ocidentais. São convergentes e, em

${ }^{211}$ Disponível em: http://www.legislacao.vlex.pt/vid/testemunhas-processo-penal-469197. Acesso em: 29 set. 2009.

${ }^{212}$ RUSSO, Luciana; GEMAQUE, Silvio César Arouck. Crime organizado em Portugal. In: FERNANDES, Antonio Scarance; ALMEIDA, José Raul Gavião de; MORAES, Maurício Zanoide (Org.). Crime organizado - aspectos processuais, p. 296. Descrevem os requisitos legais: 1. O depoimento ou declarações respeitarem crimes do catálogo; 2. a testemunha, seus familiares ou outras pessoas que lhes sejam próximas correrem um grave perigo de atentado contra a vida, a integridade física, a liberdade ou bens patrimoniais de valor consideravelmente elevado; 3 . não ser fundadamente posta em dúvida a credibilidade da testemunha; e 4. o depoimento ou declarações constituírem um contributo probatório de relevo (ibidem, p. 296-297).

${ }^{213}$ Art. 19, no 2 do Código de Processo Penal (RUSSO, Luciana; GEMAQUE, Silvio César Arouck. Crime organizado em Portugal. In: FERNANDES, Antonio Scarance; ALMEIDA, José Raul Gavião de; MORAES, Maurício Zanoide (Org.), op. cit., p. 296).

${ }^{214}$ MARTINS, Teresa Alves; ROCHA, Rosa Maria. Prova e sucedâneos de prova em processo penal Relatório Nacional de Portugal. In: Prova e sucedâneos da prova no processo penal. Revista Brasileira de Ciências Criminais, São Paulo: RT, v. 66, maio-jun. 2007, p. 201. O autor, citando as relatoras portuguesas, descreve ainda que existe preocupação em não se desguarnecer a posição da defesa, e, por isso, com base na jurisprudência do Tribunal europeu, não se permite que a condenação se baseie exclusiva ou predominantemente em declarações anônimas.

${ }^{215}$ Ibidem, loc. cit. 
média, todos das duas últimas décadas, com exceção do programa americano, da década de 1970, muito embora com outro enfoque.

Interessante notar que os programas todos, que se diferenciam em detalhes, acabam se especializando na proteção de réus colaboradores, o que demonstra uma tendência moderna, até mesmo para atingir a estrutura do crime organizado, pois como já se concluiu, esta talvez seja a única forma de proporcionar ao membro de organização criminosa a sua retirada da gangue.

\subsection{Programas de proteção no Brasil}

No Brasil, o programa pioneiro foi o criado pelo Gabinete de Assessoria Jurídica às Organizações Populares do Estado de Pernambuco em janeiro 1996, quando recebeu a primeira testemunha protegida ${ }^{216}$. O projeto ganhou realidade com o Programa de Proteção a Testemunhas (Provita), contando com um advogado. dois psicólogos e uma assistente social $^{217}$. O Estado do Rio de Janeiro inaugurou, posteriormente, o Programa Estadual de Proteção a Testemunhas, gerenciado por uma entidade não governamental. Outros vários Estados iniciaram, então, estudos visando à implementação dos programas de proteção, voltados, em sua maioria, às vítimas e testemunhas de crimes praticados por policiais, grupos de extermínio ou integrantes do crime organizado.

Esse programa denomina-se Programa de Apoio e Proteção a Testemunhas e Vítimas de Violência. O site do Gabinete de Assessoria Jurídica às Organizações Populares (Gajop) $)^{218}$ indica que atualmente dez Estados já implementaram o programa: Acre, Bahia, Espírito Santo, Goiás, Mato Grosso do Sul, Minas Gerais, Pará, Pernambuco, Rio de Janeiro e São Paulo.

O Provita oferece assistência social, psicológica e jurídica por parte de sua equipe multidisciplinar e de voluntários, bolsa de trabalho e cursos profissionalizantes. A duração máxima de permanência de um beneficiário dentro do programa é, em regra, de dois anos,

\footnotetext{
216 Trata-se de entidade não governamental militante há vários anos na área de defesa dos Direitos Humanos (OLIVEIRA, Neide M. Cardoso de. Programa de proteção a testemunhas. Boletim dos Procuradores da República, v. 2, n. 13, p. 28-30, maio 1999).

${ }^{217}$ Ibidem, p. 28.

${ }^{218}$ Disponível em: http://www.gajop.org.br/provita.htm. Acesso em: 7 jan. 2009.
} 
mas em caso de necessidade, por óbvio, esse prazo deve ser estendido. É mantido por meio de uma rede de voluntários. Existem três tipos de voluntários no Provita: colaboradores, que contribuem com a manutenção do Programa mediante geração de renda, campanhas etc. Eles nunca ficam em contato direto com as testemunhas protegidas; prestadores de serviço, que são profissionais liberais, como médicos, dentistas, psicólogos, advogados, entre outros, que prestam serviços gratuitos ao programa. Os voluntários têm um contato momentâneo, muitas vezes de urgência, com os beneficiários e os protetores que são as pessoas que mantêm as testemunhas protegidas em lugares seguros.

O programa é subsidiado por verbas federais e estaduais. As verbas federais são provenientes do Ministério da Justiça, via Secretaria Nacional dos Direitos Humanos - ora Departamento Nacional de Proteção a Testemunhas -, adaptado às necessidades de cada Estado $^{219}$.

A testemunha é encaminhada ao programa pelo Ministério Público ou pela polícia, em regra, pois são os primeiros a terem contato com a realidade da ameaça à pessoa. Após entrevista com a equipe técnica, o caso é analisado pelo Conselho Deliberativo, que, então, encaminha para as providências protetivas ${ }^{220}$.

Dependendo da gravidade do caso, a testemunha ou vítima pode ser encaminhada imediatamente para o local de proteção, até mesmo como forma de salvaguardar sua vida. Trata-se de um local de "pouso", intermediário da medida de proteção perante a rede de proteção, formada por instituições religiosas, profissionais liberais e outras pessoas voluntárias.

Uma vez protegida, a testemunha poderá ter contato com a família, mas por intermédio da equipe técnica, que faz contato de forma segura e com os cuidados necessários.

\footnotetext{
${ }^{219}$ OLIVEIRA, Neide M. Cardoso de. Programa de proteção a testemunhas. Boletim dos Procuradores da República, v. 2, n. 13, p. 28.

${ }^{220}$ Ibidem, loc. cit.
} 


\subsubsection{O sigilo}

É fundamental para a manutenção do programa, o sigilo absoluto de todas as informações, sejam das testemunhas que estão acobertadas pelo programa, seja pelas demais pessoas envolvidas, pois evidencia-se que, sendo conhecidas as pessoas que trabalham para a proteção, violada estaria a proteção da testemunha.

Tudo precisa ficar em segredo, desde os nomes e endereços até os gastos efetuados para a manutenção do protegido.

A testemunha ou vítima que ingressa no programa, em regra, será levada a um lugar desconhecido dos criminosos que buscam sua eliminação. Nesse local, os protegidos não poderão sequer se identificar e ficarão sob identidade fictícia, até mesmo para que não haja identificação e comunicação ao crime organizado.

Somente os encarregados do programa - advogados, assistentes sociais e psicólogos - terão conhecimento desse local e da identidade das testemunhas protegidas, uma vez que nada pode identificá-lo.

Eventuais comunicações do processo - intimação para audiência, por exemplo deverão ser efetuadas aos encarregados do programa, os quais se responsabilizarão pelo transporte da testemunha ao Fórum ou ao Distrito Policial.

A dificuldade ocorrerá na prestação de contas, uma vez que as notas fiscais de gastos devem ser apresentadas e isso identifica o local sigiloso de moradia da testemunha protegida. Os Tribunais de Contas dos Estados estão cobrando regulamentação dessa circunstância, dado que o dinheiro utilizado é público e deve existir a correspondente prestação de contas.

No mais, ainda que o Conselho Deliberativo não tenha todas as informações dadas a necessidade de sigilo, entende-se, neste estudo, que o programa poderá ser muito bem administrado. 


\subsubsection{O financiamento}

A execução do programa é particular, em regra exercido por entidades da sociedade civil, com administração mista entre a sociedade civil e o poder público. O financiamento, todavia, é inteiramente público e tem origem no Ministério da Justiça, que efetua a dotação orçamentária com a finalidade de manutenção do programa, não só com os gastos das testemunhas protegidas, mas também com a infraestrutura e os servidores contratados.

\subsubsection{A prestação de contas}

Conforme mencionado, o financiamento é público, com execução particular. Exigese a prestação de contas dos valores utilizados, nada obstante o sigilo que é necessário para o sucesso do programa.

Evidente que aqui surgem vários problemas, notadamente em razão do sigilo para execução do programa.

O Tribunal de Contas exige a verificação completa do uso de verbas públicas, não sendo possível a omissão de dados e, no caso das verbas destinadas à utilização com testemunhas e vítimas preservadas, qualquer documento poderá servir para identificação do local de proteção.

Uma nota fiscal de compra de alimentos, v.g., poderá indicar que naquela cidade e próximo do local da compra a testemunha se encontra alocada. O Tribunal de Contas da União, por sua vez, tem exigido a devida prestação de contas.

Ainda não existe nenhuma regulamentação da matéria e, como tudo no programa brasileiro, a prestação de contas tem sido realizada de forma precária.

\subsubsection{Aspectos jurídicos não penais relacionados com o programa de proteção}

Surgem várias situações inusitadas na execução do programa de proteção de vítimas e testemunhas. Suponha-se que a testemunha deva ser protegida, mas também 
ameaçados estão seus familiares. Quais familiares deverão integrar o programa? Quantos devem ser incluídos e até que grau de parentesco?

Evidente que toda essa situação gera infinitos efeitos jurídicos. São relevantes e, por isso, serão - pelo menos alguns - tratados de forma particular.

\subsubsection{Contrato de trabalho}

A testemunha ou vítima incluída no programa deverá deixar seu emprego. Se for funcionário público será possível afastar-se do cargo sem perder sua remuneração, o que é bem viável tendo em vista a necessidade de manutenção do programa com financiamento público e não raras vezes apertado.

Todavia, a testemunha ou vítima que não faz parte dos quadros do serviço público será necessariamente desligada de seu trabalho, rompendo seu vínculo empregatício. Isso é justo? Não seria possível imaginar uma situação em que a testemunha teve muito cuidado em sua formação justamente para alcançar um posto em uma empresa e de uma hora para outra é obrigada a desligar-se e com a possibilidade de nunca mais poder exercer aquele cargo?

É lamentável, mas não existe outra hipótese, pois a suspensão do contrato de trabalho somente foi previsto para o serviço público ou militar ${ }^{221}$.

\footnotetext{
${ }^{221}$ Em relação ao serviço público, já houve discussão a respeito da possibilidade de suspensão do contrato de trabalho (veja-se Capítulo 8 sobre a Lei nº $9.807 / 99$ - medidas protetivas da lei - suspensão do contrato de trabalho) de servidor de empresa delegada de serviço público, quando um de seus funcionários foi incluído no sistema de proteção do Provita Rio (Programa de Proteção de Vítimas e Testemunhas do Estado do Rio de Janeiro). Segundo parecer do advogado Wilhiam Antônio de Melo, ainda que o funcionário não tivesse enquadramento na categoria de servidor público estatutário, suas obrigações são semelhantes, eis que não pode acumular emprego ou função pública e aposentadoria, impedimentos próprios de advocacia, além de forte corrente doutrinária no sentido de que são empregados públicos, uma espécie do gênero servidor público. Diante disso, concluiu o parecerista que a empresa pública se pauta pelos princípios da legalidade, moralidade, impessoalidade, razoabilidade, eficiência e supremacia do interesse público, não pode negar cumprimento à lei de proteção, apegando-se à literalidade minuciosa que se mostra ínfima quando comparada ao "bom direito" almejado pela Lei no 9.807/99 (MELO, Wilhiam Antônio de. Suspensão do contrato de trabalho de empregado protegido por programa de proteção a testemunha. Revista Jurídica do Ministério da Defesa, v. 1, n. 2, p. 61-64, mar. 2005).
} 


\subsubsection{Existência de processos}

Outra situação que merece análise é a da testemunha que responde a outros processos criminais.

Estabelece o Código de Processo Penal que o réu deve ser identificado, ainda que a falta disso não deva retardar o andamento do processo (art. 259, CPP). Essa determinação está parcialmente resolvida com a possibilidade de omissão do nome e identificação (vejase Provimento 32/2000). Porém, a falta de cumprimento de determinação de ato judicial acarretará ônus ao acusado/testemunha protegida (veja-se art. 260, CPP).

Além disso, outras obrigações do acusado no processo penal podem eventualmente corresponder a empecilhos no cumprimento do programa, como é o caso da obrigação prevista no artigo 328 do Código de Processo Penal em que ao réu afiançado será proibido mudar de residência ou se ausentar por mais de oito dias; bem assim, como é o caso da revelia em caso de mudança de residência (art. 367); e a possibilidade de realização de audiência no local em que se encontra o réu enfermo (art. 403).

Todavia, a situação mais complicada para o programa será a da testemunha condenada à pena privativa de liberdade ou mesmo às penas restritivas de direito, notadamente prestação de serviços à comunidade, interdição temporária de direitos ou limitação de fim de semana.

Por óbvio, não haverá possibilidade de inclusão, no programa, de testemunha presa. No caso de prestação de serviços à comunidade, também haverá certa complexidade, pois o retorno do sentenciado ao local de sua comunidade prejudica a proteção e o cumprimento da pena no local de esconderijo identifica a testemunha.

Nessa circunstância, a lei não prevê qualquer alternativa e não será possível ao juiz da execução deixar de determinar o cumprimento da pena por absoluta falta de amparo legal. 


\subsubsection{Dívidas}

Algumas testemunhas que são incluídas no programa possuem dívidas. Como já se verificou neste trabalho, é fundamental que a testemunha seja retirada de sua comunidade e notadamente de seu endereço para que a proteção seja efetiva. Com isso, seus gastos com moradia, alimentação, vestuário e outras coisas necessárias para a vida serão pagas pelo programa, mas e suas dívidas? Deverão também ser pagas pelo programa?

Não é só isso. Como administrar a situação em que a testemunha possui bens e está sendo processada por dívidas?

Entende-se, neste estudo, que as dívidas anteriores não poderão ser pagas. A previsão legal de financiamento somente atinge os gastos necessários para a sua manutenção atual. As dívidas do protegido deverão ser pagas com seu patrimônio e, na ausência deste, deverão ser administradas após sua exclusão do programa.

Outra questão que revela interesse refere-se à existência de dívida alimentar que eventualmente poderá acarretar a prisão civil da testemunha. Nesse caso, então, não havendo outra alternativa de ganhos da testemunha, a pensão deverá ser paga pelo programa, ao menos durante o tempo em que o protegido alimentante não possa ganhar seu próprio sustento.

\subsubsection{Patrimônio}

A testemunha protegida não pode ser obrigada a vender seu patrimônio, seja para a sua manutenção, seja porque não haverá possibilidade de administrá-los. Imagina-se que a testemunha incluída no programa possua bens imóveis que necessitam de administração. Por óbvio, a testemunha deixará essa administração por ser incompatível com a execução do programa de proteção. Porém, como serão pagos os valores devidos, porventura, a título de imposto predial? Ou valores de condomínio? Seria possível obrigar a testemunha a outorgar poderes a outra pessoa para a administração? 
A lei também não resolve as questões supra, que são relevantes e absolutamente complexas na administração do programa.

É preciso lembrar que todas essas circunstâncias acarretarão prejuízo ao programa na medida em que a testemunha ou vítima poderá ser identificada e localizada.

\subsubsection{Nome}

A Lei $n^{0}$ 9.807/99 traz a possibilidade de alteração do nome da testemunha ou vítima. Descreve o artigo 9ำ que, "em casos excepcionais e considerando as características e gravidade da coação ou ameaça, poderá o conselho deliberativo encaminhar requerimento da pessoa protegida ao juiz competente para registros públicos objetivando a alteração de nome completo". Nesse caso, então, a testemunha ou vítima mudam sua identidade e, embora isso possa ocorrer de forma provisória, pois o mesmo artigo, no $\S 5^{-}$, faz referência ao retorno do nome original, isso acarretará inúmeras circunstâncias jurídicas relevantes. Imagina-se que a testemunha esteja com seu contrato de serviço público suspenso, mas recebendo seus rendimentos. Não poderá se identificar em bancos ou outras entidades de crédito para a administração de seu dinheiro. Imagina-se que a testemunha não possa trabalhar com o nome novo porque não existe previsão legal para a emissão de carteira de trabalho ou registro no órgão de previdência fictícios.

Essas são algumas das situações jurídicas relevantes não regulamentadas pela lei e que eventualmente podem ocorrer acarretando problemas inúmeros para a execução do programa.

Outras questões deverão ainda ser desenvolvidas, como a existência de registro público no caso de bens imóveis e as questões fiscais pessoais. Ainda será possível analisar eventual responsabilidade civil do Estado em face de todo o prejuízo sofrido pela testemunha no período de proteção ou em razão do delito de que teve conhecimento. 


\section{DELAÇÃO PREMIADA E PROTEÇÃO AO RÉU COLABORADOR}

Cabe, neste ponto, reiterar um esclarecimento. O objetivo deste trabalho é estudar as medidas de proteção de vítimas, testemunhas e réus colaboradores, assim como previsto pela Lei $n^{0}$ 9.807/99. Era possível que a pesquisa cingisse o tema somente a vítimas e testemunhas, mas a importância da proteção de réus colaboradores não permite essa regalia.

Em primeiro lugar, porque o estudo não ficaria completo, pois a Lei $\mathrm{n}^{0}$ 9.807/99 faz previsão expressa para a proteção de réus colaboradores, incentiva a delação e estipula isenção de pena ou sua redução, diferentemente de outros diplomas legais que tratam do tema. Depois, porque, tanto no Brasil quanto em outros países que adotam o sistema de proteção de testemunhas, o número de réus colaboradores protegidos é muito relevante ${ }^{222}$.

Importa, dessa forma, estudar, ainda que de forma menos aprofundada, mas bastante para o instituto da proteção, a delação premiada. Ainda que criticado o instituto da delação premiada ${ }^{223}$, não se constatou divergência no sentido de que os réus colaboradores igualmente sejam merecedores de proteção por parte do Estado ${ }^{224}$.

A delação premiada também é mecanismo de efetividade do processo penal que representa a revelação de dados importantes sobre o delito no concernente aos demais autores e circunstâncias fáticas, pelo acusado, em troca de benefícios que serão avaliados pelo juiz da causa.

\footnotetext{
${ }^{222}$ Para se ter uma ideia, no ano de 1997, das 1.901 pessoas protegidas na Itália, 1.040 eram provenientes do quadro de criminosos, cuja investigação perseguia (LOURENÇO, Messias José. Crime organizado e lei de proteção de testemunhas. Lex - Jurisprudência do Superior Tribunal de Justiça e Tribunais Regionais Federais, v. 16, n. 181, p. 9-22). Nos Estados Unidos, 67\% dos novos casos que ingressam no programa são originários de crimes praticados pelas gangues. Em geral, os protegidos são informantes da polícia, membros de gangues rivais, traficantes rivais, namoradas ou esposas ou as "ex" e, também, pessoas da comunidade (veja-se abordagem sobre os Estados Unidos, no Capítulo 8 deste trabalho que trata dos programas de proteção no direito estrangeiro).

${ }^{223}$ Até bem recentemente, o instituto da delação premiada não despertava muito interesse na comunidade jurídica, embora existente no ordenamento brasileiro há exatos 15 anos. Nunca teve grande aplicação na prática, e isso se deve, em parte, ao entendimento majoritário de que: falta-lhe fundamento ético; a colaboração constitui ato de traição; de que viola o princípio de que a pena deve ser imposta na medida da culpabilidade do agente; de que sua concessão viola a Constituição da República; espelha um sistema penal falido, incapaz de desmantelar organizações criminosas ou até mesmo de solucionar pequenos delitos; significa "barganha com a criminalidade" (MOURA, Maria Thereza Rocha de Assis. Delação premiada. Revista Del Rey Jurídica, Belo Horizonte, ano 8, n. 16, p. 67-70, 1ํㅗㅇ. sem. 2006, p. 67).

${ }^{224}$ LOURENÇO, Messias José, op. cit., p. 9-22.
} 
O instituto, de natureza decorrente do "princípio do consenso" - variante do princípio da legalidade -, permite às partes conciliarem a respeito do destino da situação jurídica do acusado que, por qualquer razão, concorda com a imputação ${ }^{225}$.

A delação teve reconhecimento como instrumento processual inicialmente na Itália, com a introdução da legislação antiterrorista e também no artigo 630 do Código Penal italiano que estabeleceu benefícios ao delator que propiciasse a liberação de sequestrado ou a coleta de provas $^{226}$.

Na Itália, são três as espécies de colaboradores: pentiti (arrependidos, que saíram dos bandos antes de sofrerem qualquer condenação e trazem à colação as informações necessárias para a investigação da estrutura criminosa da organização); dissociati (os dissociados, que em termos gerais não estão arrependidos, mas sua atuação não contribuiu para as consequências danosas dos crimes ou impediram a prática de crimes conexos, confessando, entretanto, toda a infração); e colaboratori della giustizia (colaboradores da justiça, que, além das informações e práticas previstas para as duas espécies anteriores, ainda contribuem efetivamente para individualizar e capturar os outros integrantes do grupo organizado, fornecendo provas exatas sobre a infração) ${ }^{227}$.

Como se verifica do ordenamento jurídico brasileiro, a delação premiada está prevista em vários dispositivos legais e cada uma traz uma aplicação diferente. Alguns limitam à aplicação de crimes específicos, outros limitam o próprio benefício e, por vezes, estabelecem o requisito da espontaneidade. Além disso, a nomenclatura também é diferenciada: denúncia, colaboração espontânea, confissão espontânea, colaboração efetiva e voluntária, colaboração voluntária, revelação espontânea e revelação eficaz ${ }^{228}$.

É fácil verificar, também, que o instituto foi sendo adotado no decorrer do tempo, tendo início com a Lei $\mathrm{n}^{\mathrm{o}}$ 7.492/86 até chegar à Lei $\mathrm{n}^{\mathrm{o}}$ 9.807/99, que é, sem dúvida, a mais ampla possível.

Considera-se, nesta pesquisa, interessante analisar de forma breve cada um dos diplomas mencionados, mas para o estudo do instituto da delação premiada, entende-se,

\footnotetext{
${ }^{225}$ MENDRONI, Marcelo Batlouni. Crime organizado - aspectos gerais e mecanismos legais, p. 37.

${ }^{226}$ MOURA, Maria Thereza Rocha de Assis. Delação premiada. Revista Del Rey Jurídica, ano 8, n. 16 , p. 68.

${ }^{227}$ KAWAMOTO, Silvia Reiko. Breves apontamentos sobre o crime organizado e a proteção à testemunha na Itália e nos Estados Unidos. Revista Justiça Penal, São Paulo: RT, n. 7, 2000. p. 417.

${ }^{228}$ MOURA, Maria Thereza Rocha de Assis, op. cit., p. 69.
} 
por algumas razões apontadas a seguir, necessário cingir os fundamentos de acordo com a Lei $n^{0}$ 9.807/99.

A primeira e principal dessas razões refere-se ao fato de que o objeto deste trabalho tem por foco as medidas de proteção aos réus colaboradores como mecanismo de efetividade do processo penal, ou seja, a este trabalho não interessa os benefícios de redução de pena ou mesmo perdão judicial, muito embora seja impossível discutir delação premiada sem verificar tais consequências, mas o centro devem ser as medidas de proteção efetivas para o réu colaborador e isso somente foi previsto na Lei n⿳ำ 9.807/99.

A segunda razão alude à questão de que, como último diploma legislativo a respeito, é possível que se considere um, outro ou todos os demais revogados e, por fim, a disposição da lei mais nova é infinitamente mais abrangente, incluindo até aqueles crimes específicos de lavagem de dinheiro, crimes tributários, hediondos, tortura, organização criminosa e tráfico de entorpecentes.

Conforme salientado, é, no entanto, importante proceder a breve análise dos dispositivos legais, até para contribuir no estudo da evolução histórica e, eventualmente, poder interpretar a lei de acordo com o entendimento desenvolvido no tempo.

Descreve o artigo $6^{\circ}$ da Lei $n^{\circ}$ 9.034/95 que, "nos crimes praticados em organização criminosa, a pena será reduzida de um a $2 / 3$ (dois terços), quando a colaboração espontânea do agente levar ao esclarecimento de infrações penais e sua autoria". Nesse caso, a lei limitou-se a estabelecer a delação premiada somente para os crimes praticados em "organização criminosa", o que gera várias dificuldades, dado que essa mesma lei não estabelece tal crime e nem define "organização criminosa". Também estabelece de forma genérica que o resultado da "colaboração espontânea" do agente deva "levar ao esclarecimento de infrações penais e sua autoria", deixando ao sabor da interpretação o vínculo de causalidade entre as tais informações e o efetivo esclarecimento.

A Lei n⿳0 9.613/98, que trata dos crimes de "lavagem" ou ocultação de bens, direitos e valores e outras questões de ordem financeira, também fez previsão da delação premiada no artigo $1^{\circ}, \S 5^{\circ}$, que diz:

“A pena será reduzida de 1 (um) a 2/3 (dois terços) e começará a ser cumprida em regime aberto, podendo o juiz deixar de aplicá-la ou substituí-la por pena restritiva de direitos, se o autor, co-autor ou partícipe 
colaborar espontaneamente com as autoridades, prestando esclarecimentos que conduzam à apuração das infrações penais e de sua autoria ou à localização dos bens, direitos ou valores objeto do crime."

Nessa situação a legislação foi bem mais completa, estabelecendo os requisitos para a ocorrência da delação, assim como os eventuais benefícios que poderão ser concedidos pelo juiz.

A Lei n⿳0 9.807/99, objeto específico deste estudo, e que também faz previsão para a delação premiada em capítulo próprio denominando "Da proteção aos réus colaboradores", estabelece os requisitos legais para a ocorrência do instituto.

Interessante notar que, no caso da lei em comento, não há definição do crime em que a delação premiada deva ocorrer como são os casos dos demais diplomas estudados. Aqui - na lei de proteção de testemunhas -, poderá o juiz conceder perdão judicial e extinção da punibilidade ou redução de pena ou, ainda, medidas especiais de proteção e segurança fora ou dentro de institutos prisionais. A lei, aliás, ainda estabelece a possibilidade de a União se utilizar de estabelecimentos prisionais destinados em especial ao cumprimento de pena de condenados que tenham prévia e voluntariamente prestado colaboração.

A Lei de Crimes Hediondos, de $n^{0}$ 8.072/90, também faz previsão da delação no artigo $8^{\underline{0}}$, no qual regula:

“(...) Será de 3 (três) a 6 (seis) anos de reclusão a pena prevista no art. 288 do Código Penal, quando se tratar de crimes hediondos, prática da tortura, tráfico ilícito de entorpecentes e drogas afins ou terrorismo.

Parágrafo único. O participante e o associado que denunciar à autoridade o bando ou quadrilha, possibilitando seu desmantelamento, terá a pena reduzida de 1 (um) a 2/3 (dois terços)."

A Lei de Crimes Hediondos estabeleceu a possibilidade de redução de pena para a denúncia que trouxer o "desmantelamento" do bando ou quadrilha, sendo específica em relação ao crime, requisitos e benefícios. 
A Lei $\mathrm{n}^{\mathrm{o}}$ 8.137/90, que define crimes contra a ordem tributária, também faz previsão de redução de pena e para os crimes praticados por quadrilha ou bando previstos na aludida legislação, descrevendo o artigo 16, parágrafo único: "Nos crimes previstos nesta Lei, cometidos em quadrilha ou co-autoria, o co-autor ou partícipe que através de confissão espontânea revelar à autoridade policial ou judicial toda a trama delituosa terá a sua pena reduzida de 1 (um) a 2/3 (dois terços)".

A mesma descrição, inclusive com o requisito de que a revelação deva ser de toda a "trama delituosa", também está prevista na Lei nº 7.492/86, que define crimes contra a ordem financeira.

Por fim, a Lei $\mathrm{n}^{\mathrm{o}}$ 9.269/96, que introduziu a tipicidade do crime de extorsão mediante sequestro praticado em concurso, situação em que possibilita a delação, prevendo o $\S 4^{\circ}$ do artigo 159: "Se o crime é cometido em concurso, o concorrente que o denunciar à autoridade, facilitando a libertação do sequestrado, terá sua pena reduzida de 1 (um) a 2/3 (dois terços)".

O Quadro 9.1, na página a seguir, contribui para melhor visualização dos vários dispositivos. 
Quadro 9.1 - Delação Premiada: resumo dos vários dispositivos

\begin{tabular}{|c|c|c|c|c|}
\hline Lei n & Benefício & Colaboração & Crimes & Requisitos \\
\hline $\begin{array}{l}9.034 / 95 \\
\left(\text { art. } 6^{\circ}\right)\end{array}$ & - redução de 1 a $2 / 3$ & $\begin{array}{l}\text { - colaboração espontânea do agente } \\
\text { que levem ao esclarecimento de } \\
\text { infrações penais e sua autoria }\end{array}$ & $\begin{array}{l}\text { - crimes } \\
\text { praticados em } \\
\text { organização } \\
\text { criminosa }\end{array}$ & - sem requisitos específicos \\
\hline $\begin{array}{l}\text { 9.613/98 } \\
\text { - trata dos } \\
\text { crimes de } \\
\text { "lavagem" ou } \\
\text { ocultação de } \\
\text { bens, direitos e } \\
\text { valores e outras } \\
\text { questões de } \\
\text { ordem } \\
\text { financeira } \\
\left(\text { art. } 1^{\circ}, \S 5^{\circ}\right) \text {. }\end{array}$ & $\begin{array}{l}\text { - redução de } 1 \text { a } 2 / 3 \text { e } \\
\text { começará a ser } \\
\text { cumprida em regime } \\
\text { aberto, podendo o juiz } \\
\text { deixar de aplicá-la ou } \\
\text { substituí-la por pena } \\
\text { restritiva de direitos }\end{array}$ & $\begin{array}{l}\text { - colaboração do autor, coautor ou } \\
\text { partícipe, espontaneamente, com as } \\
\text { autoridades, prestando } \\
\text { esclarecimentos que conduzam à } \\
\text { apuração das infrações penais e de } \\
\text { sua autoria ou à localização dos } \\
\text { bens, direitos ou valores objeto do } \\
\text { crime }\end{array}$ & $\begin{array}{l}\text { - crimes } \\
\text { previstos na lei } \\
\text { específica de } \\
\text { "lavagem" ou } \\
\text { ocultação de } \\
\text { bens, direitos e } \\
\text { valores e outras } \\
\text { questões de } \\
\text { ordem financeira }\end{array}$ & - sem requisitos específicos \\
\hline $\begin{array}{l}8.072 / 90 \\
\text { - Lei de Crimes } \\
\text { Hediondos } \\
\left(\text { art. } 8^{\circ}\right)\end{array}$ & $\begin{array}{l}\text { - redução de } 1 \text { a } 2 / 3 \text { da } \\
\text { pena }\end{array}$ & $\begin{array}{l}\text { - o participante e o associado que } \\
\text { denunciem à autoridade o bando ou } \\
\text { quadrilha, possibilitando seu } \\
\text { desmantelamento }\end{array}$ & $\begin{array}{l}\text { - crimes } \\
\text { previstos no } \\
\text { caput }\end{array}$ & $\begin{array}{l}\text { - o caput estabelece: "Será de } 3 \\
\text { (três) a } 6 \text { (seis) anos de reclusão } \\
\text { a pena prevista no art. } 288 \text { do } \\
\text { Código Penal, quando se tratar } \\
\text { de crimes hediondos, prática da } \\
\text { tortura, tráfico ilícito de } \\
\text { entorpecentes e drogas afins ou } \\
\text { terrorismo". }\end{array}$ \\
\hline $\begin{array}{l}7.492 / 86 \text { e } \\
8.137 / 90 \\
\text { - definem } \\
\text { crimes contra a } \\
\text { ordem tributária } \\
\text { (art. 16, } \\
\text { parágrafo } \\
\text { único). }\end{array}$ & $\begin{array}{l}\text { - redução de } 1 \text { a } 2 / 3 \\
\text { (dois terços) da pena }\end{array}$ & $\begin{array}{l}\text { - nos crimes cometidos em quadrilha } \\
\text { ou em coautoria, o coautor ou } \\
\text { partícipe que mediante confissão } \\
\text { espontânea revele à autoridade } \\
\text { policial ou judicial toda a trama } \\
\text { delituosa }\end{array}$ & $\begin{array}{l}\text { - crimes } \\
\text { praticados por } \\
\text { quadrilha ou } \\
\text { bando previstos } \\
\text { na aludida } \\
\text { legislação }\end{array}$ & - sem requisitos específicos \\
\hline $\begin{array}{l}9.269 / 96 \\
\text { - introduziu a } \\
\text { tipicidade do } \\
\text { crime de } \\
\text { extorsão } \\
\text { mediante } \\
\text { sequestro } \\
\text { praticado em } \\
\text { concurso } \\
(\text { art. } 159, \\
\left.\S 4^{\circ}, \mathrm{CP}\right)\end{array}$ & $\begin{array}{l}\text { - redução de } 1 \text { a 2/3 da } \\
\text { pena }\end{array}$ & $\begin{array}{l}\text { - se o crime é cometido em } \\
\text { concurso, o concorrente que o } \\
\text { denunciar à autoridade, facilitando a } \\
\text { libertação do sequestrado }\end{array}$ & $\begin{array}{l}\text { - crimes de } \\
\text { extorsão } \\
\text { mediante } \\
\text { sequestro } \\
\text { praticados em } \\
\text { concurso }\end{array}$ & - sem requisitos especiais \\
\hline $\begin{array}{l}9.807 / 99 \\
\text { - resultado } \\
\text { efetivo }\end{array}$ & $\begin{array}{l}\text { - concessão de perdão } \\
\text { judicial e consequente } \\
\text { extinção da } \\
\text { punibilidade }\end{array}$ & $\begin{array}{l}\text { - colaboração efetiva e voluntária de } \\
\text { acusado com a investigação de } \\
\text { processo criminal, resultando na } \\
\text { identificação dos demais coautores } \\
\text { ou partícipes da ação criminosa; a } \\
\text { localização da vítima com a sua } \\
\text { integridade física preservada; a } \\
\text { recuperação total ou parcial do } \\
\text { produto do crime }\end{array}$ & $\begin{array}{l}\text { - não especifica } \\
\text { os crimes }\end{array}$ & $\begin{array}{l}\text { - somente a réus primários, } \\
\text { levando em consideração a } \\
\text { personalidade do beneficiado e } \\
\text { natureza, circunstâncias, } \\
\text { gravidade e repercussão social } \\
\text { do fato criminoso }\end{array}$ \\
\hline $\begin{array}{l}9.807 / 99 \\
\text { - colaboração }\end{array}$ & $\begin{array}{l}\text { - redução de } 1 \text { a 2/3 da } \\
\text { pena }\end{array}$ & $\begin{array}{l}\text { - colaboração voluntária de indiciado } \\
\text { ou acusado com a investigação } \\
\text { policial e o processo criminal, para a } \\
\text { identificação dos demais coautores } \\
\text { ou partícipes da ação criminosa; a } \\
\text { localização da vítima com vida; a } \\
\text { recuperação total ou parcial do } \\
\text { produto do crime }\end{array}$ & $\begin{array}{l}\text { - não especifica } \\
\text { os crimes }\end{array}$ & - não há requisitos específicos \\
\hline $\begin{array}{l}9.807 / 99 \\
\text { - réus } \\
\text { colaboradores } \\
\text { presos }\end{array}$ & $\begin{array}{l}\text { - medidas especiais de } \\
\text { segurança e proteção a } \\
\text { sua integridade física - } \\
\text { em caso se prisão } \\
\text { processual, a separação } \\
\text { dos demais presos -, } \\
\text { concessão de medidas } \\
\text { cautelares durante a } \\
\text { instrução processual }\end{array}$ & $\begin{array}{l}\text { - qualquer colaboração prevista nos } \\
\text { itens anteriores }\end{array}$ & $\begin{array}{l}\text { - não especifica } \\
\text { os crimes }\end{array}$ & - não há requisitos específicos \\
\hline
\end{tabular}


A Lei $n^{0}$ 9.807/99 estabelece duas hipóteses diferentes para aplicação da delação premiada. A primeira na qual exige resultado, expondo as situações que, necessariamente, devem surgir da colaboração do réu. Para isso, estabelece até mesmo perdão judicial, benefício até então não previsto nos diplomas legais. Na segunda hipótese, a lei considera que a colaboração, ainda que não eficaz do ponto de vista dos resultados obtidos, poderá ser premiada e concede a tradicional redução de pena.

Prevê a Lei nº 9.807/99:

“Art. 13. Poderá o juiz, de ofício ou a requerimento das partes, conceder
o perdão judicial e a conseqüente extinção da punibilidade ao acusado
que, sendo primário, tenha colaborado efetiva e voluntariamente com a
investigação e o processo criminal, desde que dessa colaboração tenha
resultado:
I - a identificação dos demais co-autores ou partícipes da ação criminosa;
II - a localização da vítima com a sua integridade física preservada;
III - a recuperação total ou parcial do produto do crime.
Parágrafo único. A concessão do perdão judicial levará em conta a
personalidade do beneficiado e a natureza, circunstâncias, gravidade e
repercussão social do fato criminoso.”

A primeira questão a ser analisada é a de quem pode ser beneficiado com perdão judicial: o acusado. Isso significa, inicialmente, que não se trata da testemunha ou qualquer outro informante no processo. Somente ao "acusado" é que o benefício pode ser outorgado, ainda que a colaboração ocorra na investigação que antecede o processo.

No processo penal, o acusado só pode assim ser chamado após a apresentação formal, pelo órgão acusador, de uma acusação, que em regra vem efetuada na denúncia. Ou seja, o benefício somente será concedido após oferecimento formal de acusação, ainda que a colaboração tenha ocorrido anteriormente.

Ensina Tourinho Filho:

"Imputado, acusado ou réu, segundo a terminologia do nosso Código, é o sujeito processual contra quem se pede a atuação do Direito Penal, contra quem res in judicio deducitur. Em uma palavra: é a pessoa contra quem 
se propõe a ação penal. Vale salientar, todavia, que o autor do fato delituoso só adquire a qualidade de imputado, acusado ou réu, no instante mesmo em que se deduz em juízo a pretensão punitiva, isto é, quando se oferece a denúncia ou queixa"229.

O que não significa, no entanto, que a colaboração prevista no dispositivo para delação premiada não possa ter ocorrido anteriormente ao oferecimento da denúncia. A condição para isso é a de que ocorra de forma voluntária.

A colaboração voluntária deve significar algo mais que espontâneo. Por óbvio, não se exigirá que o acusado tome a iniciativa de oferecimento de informações com o fito de colaborar. Isso pode partir das autoridades policial ou judicial, ou, ainda, do Ministério Público em um primeiro momento.

Não é de se exigir que a voluntariedade se torne iniciativa, mesmo porque o acusado talvez nem mesmo tenha conhecimento dos benefícios que poderia alcançar com tal colaboração e o dispositivo não busca heróis que tenham se convertido logo após a instauração da investigação policial.

O requisito voluntário quer dizer isento de qualquer pressão ou medidas coativas, ainda que lícitas. É possível, no entanto, admitir que o acusado colabore unicamente em razão do benefício que lhe é prometido pela lei. Explica Decomain:

“A voluntariedade deve, a seu turno, ser interpretada como manifestação
decorrente da vontade do próprio partícipe ou co-autor que se dispõe a
colaborar. Embora tal afirmativa pareça uma redundância, foi produzida
basicamente com o propósito de distinguir a voluntariedade da
espontaneidade. Efetivamente, não é preciso que a colaboração do
partícipe ou co-autor seja espontânea. Basta que resulte da sua vontade.
Não é indispensável, todavia, para a incidência dos dispositivos, que a
colaboração tenha sido espontânea. A iniciativa da colaboração pode não
partir do partícipe ou co-autor. Pode efetivamente ser induzida pelos
próprios agentes da investigação ou mesmo pelo Ministério Público ou

${ }^{229}$ TOURINHO FILHO, Fernando da Costa. Processo penal. São Paulo: Saraiva, 1990. v. 2, p. 381. 
pelo juiz do processo criminal, no momento do interrogatório (desde que, por óbvio, dito induzimento se opere por meios lícitos). O partícipe ou co-autor pode efetivamente ser convencido pelas autoridades a prestar sua colaboração, acenando-se-lhe com a possibilidade da obtenção do perdão judicial ou, pelo menos, da redução de pena. Tal induzimento (convencimento seria melhor) não descaracteriza a voluntariedade da colaboração e, por isso mesmo, não impede a incidência das regras dos artigos 13 ou 14 da Lei, conforme o caso"230.

A colaboração, então, pode ocorrer em qualquer tempo, na investigação ou no processo criminal. Deve, no entanto, ser efetiva e obter os resultados especificados no dispositivo. Não se trata, assim, de mera informação cujo resultado dependa da ação investigatória da polícia, mas que alcance os resultados necessários. São três os resultados esperados, concretizando-se a colaboração efetiva com a ocorrência de apenas um deles:

- a identificação dos demais co-autores ou partícipes da ação criminosa;

- a localização da vítima com a sua integridade física preservada; e

- a recuperação total ou parcial do produto do crime.

A primeira situação é a da identificação dos demais coautores ou partícipes da ação criminosa. O dispositivo já parte da premissa de que a conduta criminosa foi praticada em concurso de pessoas, presume a participação pela forma como foi praticado o crime ou existem, no mínimo, indícios da ocorrência do concurso subjetivo.

Note-se que a lei faz previsão de que a autoridade policial ou judicial já tenha conhecimento da existência de outros autores ou partícipes. Isso ocorre, em particular, para que o autor não seja beneficiado com o perdão judicial pelo fato de ter indicado outra pessoa somente para alcançar o benefício.

\footnotetext{
${ }^{230}$ DECOMAIN, Pedro Roberto. Proteção a testemunhas: redução de pena para o acusado que colabora com a investigação criminal. Revista do Ministério Público/Ministério Público do Estado do Rio de Janeiro, $\mathrm{n}$. 12, p. 183. As anotações do autor aos artigos 13 e 14 da Lei constituem tese defendida por ocasião do $13^{\circ}$ Congresso Nacional do Ministério Público, realizado na cidade de Curitiba, PR, entre os dias 26 e 29 de outubro de 1999, e aprovada naquele Congresso.
} 
O juiz competente deverá, pois, analisar a situação e verificar se efetivamente houve a participação daquele outro ou se a indicação foi falsa.

Algumas questões se colocam para discussão, como a possibilidade de o coautor indicado também fazer uso do instituto e ser beneficiado com a delação. Nota-se, neste estudo, que, na situação em comento, o coautor indicado e que agora também faz parte da relação processual possa gozar do benefício previsto no artigo 13 da Lei $n^{0}$ 9.807/99, mas somente se existir ainda vítima a ser resgatada ou para recuperação do produto do crime.

Inexistente a possibilidade de colaboração para alcançar o resultado estipulado, restará ao coautor que integrou posteriormente a relação processual somente ser beneficiado com a atenuante da confissão espontânea, caso isso ocorra. Não deve essa situação causar nenhuma estranheza, pois o primeiro acusado, por haver indicado o coautor, se beneficiou com perdão judicial e o segundo, por não haver mais nada a colaborar, terá, no máximo, atenuante genérica.

Outra questão para o debate é se houver mais de dois autores, pois se questiona se o acusado deve indicar todos ou se um somente já lhe daria o direito ao benefício. É entendimento deste pesquisador que, nesse caso, a indicação deve ser de todos os participantes, pois o objetivo da lei é alcançar a todos os autores do fato. Evita-se, com isso, abrir a possibilidade de colaboração de cada um dos coautores, de acordo com a vinda aos autos, concedendo-se perdão judicial a todos menos ao último, que poderia até ser o de menor participação.

Basta ao acusado dizer o nome dos seus coautores? Evidente que não. A identificação é necessária. Seria possível se discutir sobre o local em que o coautor pudesse ser encontrado, mas exigir essa informação talvez não fosse devido porque é cediça a possibilidade de locomoção rápida e eficaz para despistar a investigação.

É necessário ter em vista, que esse instituto não pode ser utilizado de qualquer forma, ou seja, ainda que em qualquer crime isso possa ocorrer, pois em todas as situações em que houver concurso subjetivo poderá haver indicação dos coautores, sendo necessário que o juiz analise a gravidade e a repercussão social do fato criminoso.

Decomain acrescenta a possibilidade real de aplicação da lei penal ao explicar que: 
“Apenas identificá-los (os demais participantes), todavia, não é suficiente. É necessário também reunir elementos de prova capazes de conduzir à sua efetiva punição. Como a chamada do co-réu, desde que este também confesse a sua própria participação e a atribuição de autoria que faça em relação aos demais não seja motivada por razões subalternas (vingança etc.), é elemento de prova capaz de embasar condenação criminal, quando aliado a outros, tem-se que não apenas o auxílio na identificação, mas também o fornecimento desse elemento de prova para a condenação dos demais devem permitir ao colaborador usufruir, no mínimo, da redução de pena prevista pelo art. 14 da Lei. (...) A concessão do perdão judicial, previsto pelo art. 13 da Lei $\mathrm{n}^{0}$ 9.807/99, não é obrigatória. Isso resulta claro não apenas do próprio caput do artigo, de acordo com o qual o juiz poderá conceder perdão judicial e conseqüente extinção da punibilidade ao co-autor ou partícipe, desde que seja primário e a sua colaboração conduza a algum dos resultados previstos nos incisos do próprio artigo, como também do contido em seu parágrafo único. De acordo com aquele parágrafo, segundo já se viu, a concessão do perdão judicial deverá levar em conta a personalidade do beneficiado e a natureza, circunstâncias, gravidade e repercussão social do fato criminoso, $^{, 231}$.

A segunda situação prevista pelo dispositivo é a da localização da vítima com a sua integridade física preservada.

Nesse caso específico, a lei limita a aplicação da delação para uma espécie de crime, qual seja, extorsão mediante sequestro. Enquanto as duas outras situações identificação de coparticipantes e recuperação do produto do delito - possibilitem a aplicação a todas as espécies de crimes, aqui a aplicação é pontual.

Não houve nenhuma distinção na linguagem legislativa e não caberia ao intérprete distinguir onde o legislador não fez a distinção. Na aplicação da lei não se verifica, no entanto, outra possibilidade de "localização da vítima com sua integridade preservada" que

\footnotetext{
${ }^{231}$ DECOMAIN, Pedro Roberto. Proteção a testemunhas: redução de pena para o acusado que colabora com a investigação criminal. Revista do Ministério Público/Ministério Público do Estado do Rio de Janeiro, $\mathrm{n}$. 12, p. 184.
} 
não no sequestro. De qualquer forma, fica estabelecido que não houve qualquer distinção pelo legislador a todas as possibilidades previstas no artigo 13 da Lei $\mathrm{n}^{0}$ 9.807/99.

Eis aqui uma situação de alteração de lei anterior, pois trouxe nova disciplina para os casos de sequestro. A Lei $\mathrm{n}^{\mathrm{o}}$ 9.269/96, que introduziu a tipicidade do crime de extorsão mediante sequestro praticado em concurso (art. 159, $\S 4^{\circ}, \mathrm{CP}$ ), definiu a possibilidade de delação com a finalidade de "facilitar" a libertação do sequestrado, mas limitou o benefício à redução de pena de um a dois terços. Agora, de forma ampla, possibilita o perdão judicial se a vítima for resgatada com sua integridade física preservada.

Estaria revogado o dispositivo do artigo $159, \S 4^{\circ}$, do Código Penal, uma vez que a Lei $\mathrm{n}^{\mathrm{o}}$ 9.807/99 acrescenta o benefício do perdão judicial ao réu colaborador nas condições expostas no artigo 13 ?

Este pesquisador entende que não. Ainda que a novel legislação faça previsão de um novo benefício, a questão foi tratada de forma diversa, ou seja, na lei que alterou o Código Penal a previsão da contribuição se resumiu à facilitação e, ainda que exija o resultado, se verifica contribuição menos rigorosa. Ademais, o artigo 14, em seguida, proporciona semelhante definição para a colaboração do réu arrependido.

Por fim, a terceira situação da recuperação total ou parcial do produto do crime.

Cabe observar, aqui, a possibilidade de aplicação dos benefícios previstos no artigo 13 aos que não sendo coautores ou partícipes venham a colaborar com as investigações do crime, v.g., o usuário em relação ao delito de tráfico ilícito de entorpecente.

Seria cabível a aplicação por analogia?

A analogia in bonam partem é cabível no direito penal, conforme entendimento esposado por doutrinadores de renome.

A Lei n⿳0 9.807/99 ainda prevê:

"Art. 14. O indiciado ou acusado que colaborar voluntariamente com a investigação policial e o processo criminal na identificação dos demais co-autores ou partícipes do crime, na localização da vítima com vida e na recuperação total ou parcial do produto do crime, no caso de condenação, terá pena reduzida de 1 (um) a 2/3 (dois terços)." 
Aqui a situação é somente de redução de pena e se aplica ao acusado que “colaborar voluntariamente", não aparecendo o requisito da efetividade. Isso significa que, nesse caso, a colaboração pode não ter resultado favorável e absoluto, muito embora o réu colaborador tenha se esmerado e trazido informações importantes para a identificação de coautores, localização de vítimas e recuperação de produtos de crime.

Insta salientar que, em quaisquer das situações previstas, a mesma lei prevê as "medidas especiais de segurança e proteção a sua integridade física, considerando ameaça ou coação eventual ou efetiva" ${ }^{232}$, o que também é considerado pela legislação italiana ${ }^{233}$.

Prevê a Lei n⿳ำ $9.807 / 99$ pátria:

“Art. 15 - Serão aplicadas em benefício do colaborador, na prisão ou fora dela, medidas especiais de segurança e proteção a sua integridade física, considerando ameaça ou coação eventual ou efetiva.

$\S 1^{o}$ - Estando sob prisão temporária, preventiva ou em decorrência de flagrante delito, o colaborador será custodiado em dependência separada dos demais presos.

$\S 2^{\underline{o}}$ - Durante a instrução criminal, poderá o juiz competente determinar em favor do colaborador qualquer das medidas previstas no art. $8^{\circ}$ desta Lei.

$\S 3^{\mathrm{o}}$ - No caso de cumprimento de pena em regime fechado, poderá o juiz criminal determinar medidas especiais que proporcionem a segurança do colaborador em relação aos demais apenados.

Art. 19 - A União poderá utilizar estabelecimentos especialmente destinados ao cumprimento de pena de condenados que tenham prévia e voluntariamente prestado a colaboração de que trata esta lei."

Eis aqui um grande desafio na execução do programa de proteção.

\footnotetext{
${ }^{232}$ Artigo 15 da Lei no ${ }^{9}$ 9.807/99.

${ }^{233}$ Além de dispor a respeito do crime de sequestro, o Decreto-lei no 8/91 - convertido na Lei no 82/91 -, estabelece importantes normas para a proteção dos colaboradores da justiça, determinando a adoção de medidas aptas a assegurar a incolumidade e, se necessário, a assistência das pessoas presas, expostas a perigo grave e atual, em consequência de sua colaboração. Tais medidas também podem ser dispostas em favor dos parentes próximos, dos conviventes e de que esteja exposto a perigo grave e iminente, por força das relações mantidas com o preso (GRINOVER, Ada Pellegrini. O crime organizado no sistema italiano. Revista dos Tribunais - Instituto Brasileiro de Ciências Criminais, São Paulo: RT, n. 12, out.-dez. 1995, p. 80).
} 
Conforme assinalado, a lei promulgada em 13 de julho de 1999 cria programas especiais de proteção que estabelecem medidas de assistência visando excluir os riscos sofridos pelas testemunhas e vítimas coagidas ou expostas ao perigo por terem colaborado com a investigação ou no processo penal. O objetivo foi criar mecanismos eficazes de proteção às pessoas que, em virtude da importância de seus depoimentos no processo penal, provocam os delinquentes perigosos e, com frequência, organizados.

Observou-se, ainda, neste trabalho, que a proteção, segundo a lei, será executada mediante providências específicas que vão desde o abrigo temporário com vigilância ininterrupta para a testemunha e seus familiares até a substituição do próprio nome da pessoa, bem como seus documentos e toda a identificação civil.

No Capítulo 8, discutiram-se os critérios e requisitos para inclusão, nos quais um deles se resume a não ser o protegido condenado que já cumpre pena e não estar sob prisão cautelar, seja qual for a modalidade.

Ora, é muito simples entender que o programa não admite "vítimas e testemunhas" que eventualmente estejam cumprindo pena ou sob prisão processual. Mas em relação aos réus colaboradores isso não pode ser vedado. Claro está que a proteção do réu colaborador é diferenciada e, como tal, deve ser aplicada de forma diversa. A remoção e escolta do protegido já determinam providências diferentes.

A lei ressalvou a necessidade de medidas no âmbito prisional, seja ao apenado, seja ao que somente responde ao feito criminal, descrevendo que "tal exclusão não trará prejuízo a eventual prestação de medidas de preservação da integridade física desses indivíduos por parte dos órgãos de segurança pública" (art. $2^{\underline{o}}, \S 2^{\underline{o}}$, parte final, Lei $\mathrm{n}^{\mathrm{o}}$ 9.807/99). Isso é complementado na parte referente ao réu colaborador (art. 15 prétranscrito).

O réu colaborador deverá ser incluído no programa como depoente especial, figura prevista no decreto regulamentador: "a pessoa que, não admitida ou excluída do Programa, corra risco pessoal e colabore na produção da prova" (art. 10 do Decreto 3.518).

Para tais "depoentes especiais", o regulamento fez previsão para algumas medidas acautelatórias de proteção, de acordo com a necessidade e situação de cada um. O artigo já 
foi reproduzido no Capítulo 8, motivo pelo qual será transcrita aqui somente a parte ora relevante:

\footnotetext{
"Art. 10 - Entende-se por depoente especial:

I - o réu detido ou preso, aguardando julgamento, indiciado ou acusado sob prisão cautelar em qualquer de suas modalidades, que testemunhe em inquérito ou processo judicial, se dispondo a colaborar efetiva e voluntariamente com a investigação e o processo criminal, desde que dessa colaboração possa resultar a identificação de autores, co-autores ou partícipes da ação criminosa, a localização da vítima com sua integridade física preservada ou a recuperação do produto do crime; e (...)

$\mathrm{V}$ - medidas especiais de segurança e proteção da integridade física, inclusive dependência separada dos demais presos, na hipótese de o depoente especial encontrar-se sob prisão temporária, preventiva ou decorrente de flagrante delito.

$\S 2^{\underline{o}}$ - Cabe ao Departamento de Polícia Federal, do Ministério da Justiça, o planejamento e a execução do Serviço de Proteção, para tanto podendo celebrar convênios, acordos, ajustes e termos de parceria com órgãos da Administração Pública e entidades não-governamentais."
}

Insta verificar, portanto, que a proteção dos réus colaboradores não se dá no mesmo formato de vítimas e testemunhas. Em primeiro lugar, compete ao Departamento de Polícia Federal e ao Ministério da Justiça a execução dos serviços de proteção para réus colaboradores e depoentes especiais, justamente pela circunstância em que se encontram.

O programa de proteção não tem qualquer possibilidade de ingerência no sistema prisional para cumprir com a obrigação de proteção ao detento protegido. Cabe ao próprio sistema providenciar essa proteção.

Por óbvio, em vista da situação do sistema prisional, não há vagas suficientes para que os estabelecimentos separem os detentos. O próprio sistema, por sua vez, cria mecanismos para a proteção de determinados tipos de detentos, dada a existência de conflitos no interior das penitenciárias e presídios de prisão provisória. 
Caberá, portanto, ao sistema essa proteção, zelando pela separação do detento e manutenção de sua vida e integridade física, consoante prevê o artigo 15 da Lei $\mathrm{n}^{\mathrm{o}}$ 9.807/99.

É pertinente observar, outrossim, que ao réu colaborador também poderão ser determinadas as medidas previstas no artigo $8^{\circ}$ da Lei $n^{0} 9.807 / 99$, que são as medidas cautelares direta ou indiretamente relacionadas com a proteção.

Imagina-se, destarte, que ao réu colaborador preso pode ser determinada a escolta especial, eventual impedimento de retirada do detento da carceragem ou a sua manutenção em prisão especial, ou, ainda, a antecipação de seu depoimento, como prevê o artigo 225 do Código de Processo Penal.

Conclui-se, pois, que a lei brasileira faz previsão expressa à isenção de pena ou sua redução para os casos de delação, assim entendida a colaboração eventual ou efetiva do réu com a investigação e o processo criminal, com o fim de identificar os demais coautores, localizar a vítima e recuperar produto de crime. Vários são os dispositivos. É possível que haja dúvida na operacionalização, mas a possibilidade de sua ocorrência é certa. A inconstitucionalidade está longe de ser uma realidade.

Também é certa a possibilidade de proteção do réu colaborador, inicialmente como qualquer testemunha ou como a vítima, se não estiver preso ou enquanto não estiver preso ou cumprindo outras medidas de execução penal ou como depoente especial se estiver integrado no sistema prisional, seja em caráter provisório ou definitivo.

Ademais, como se verificou, é relevante o número de ex-membros de organizações criminosas que contribuem com o desbaratamento da associação, a prisão de outros membros e chefes, além da punição exemplar ao crime organizado.

O exemplo italiano continua a ser seguido, pois na Itália, local de origem desse mecanismo, a proteção de réus colaboradores é o que engrossa o quadro das pessoas protegidas. Nos Estados Unidos, o programa se divide na proteção de testemunhas e réus colaboradores que se encontram presos. Aquelas são relocadas em sigilo e estes são mantidos em prisões. Os réus colaboradores significam $95 \%$ dos protegidos. Além disso, 95\% das testemunhas são delinquentes, homicidas, membros da máfia, comerciantes que 
corromperam membros do governo etc., e, desses, somente 5\% são absolutamente inocentes $^{234}$.

Importante é não permitir que as organizações criminosas consigam impor sua intimidação difusa, o silêncio à sociedade, caso em que passará a imperar o totalitário Estado-delinquencial, nos dizeres do especialista Walter Maierovitch ${ }^{235}$. Nesse caso, a população não terá mais a quem recorrer, nem mesmo à polícia e à Justiça. Será "a erosão da lei e da ordem",236.

${ }^{234}$ KAWAMOTO, Silvia Reiko. Breves apontamentos sobre o crime organizado e a proteção à testemunha na Itália e nos Estados Unidos. Revista Justiça Penal, n. 7, p. 430.

${ }^{235}$ MAIEROVITCH, Walter Fanganiello. As associações criminosas transnacionais.In: Justiça penal 3 críticas e sugestões. São Paulo: RT, 1995. p. 64.

${ }^{236}$ Ibidem, loc. cit. 


\section{CONCLUSÃO}

A tendência moderna do direito processual de buscar mecanismos de efetividade não permite a intolerância com novos institutos processuais como os de proteção de testemunhas, vítimas e réus colaboradores. A era global, marcada pela democratização da informação e pelas inovações tecnológicas, que por sua vez possibilitam a rapidez no acesso ao mercado de capitais, é testemunha de profundas mudanças na sociedade. Essas transformações promovem a evolução das relações sociais, trazendo ínsito o desvirtuamento de comportamentos, que potencializam o "aperfeiçoamento" dos crimes até então existentes, além de criarem novas modalidades.

A atual Lei (n⿳0 9.807/99) traz ao mundo jurídico matéria inovadora e que até então se encontrava sem a devida normatização, não obstante a premente necessidade de se dar guarida àqueles que de uma forma ou de outra querem colaborar com a justiça na solução dos crimes praticados.

É muito fácil notar o aumento do número de delitos praticados por organizações criminosas e que buscam igualmente a impunidade mediante ameaça ou atos mais graves contra testemunhas e vítimas. Inevitável, assim, estabelecer mecanismos de proteção a testemunhas como forma de se alcançar a prova oral necessária com o objetivo de buscar a verdade dos acontecimentos ${ }^{237}$.

A regulamentação, por sua vez, é incipiente e absolutamente lacunosa como se pôde observar ao longo do desenvolvimento deste trabalho. Necessário se faz, portanto, o aprimoramento do instituto, com sugestões legislativas e de regulamentação, diante de pesquisa das reais necessidades e em face das dificuldades processuais também apontadas.

\footnotetext{
${ }^{237}$ Nota-se que os propósitos da Lei são os melhores possíveis, seguindo uma tendência mundial e bem atendem às necessidades da sociedade. A prática de delitos graves e brutais exige do Estado medidas que possam combater a criminalidade e a impunidade. Com a finalidade de atender a essas reivindicações, surgiu a Lei $n^{0}$ 9.807/99, a qual introduz mecanismos novos, buscando resguardar a prova testemunhal, uma das mais significativas no Direito Processual brasileiro. Possibilita, por isso, a formulação de denúncias e o fornecimento de dados que viabilizem a apuração dos fatos, a identificação dos autores e a aplicação da Lei ao caso concreto, com maior efetividade. (MIGUEL, Alexandre; PEQUENO, Sandra Maria Nascimento de Souza. Comentários à lei de proteção às vítimas, testemunhas e réus colaboradores. Revista dos Tribunais, São Paulo, v. 89, n. 773, p. 425-443, mar. 2000, p. 33).
} 
Não se trata de mera alteração de procedimento como forma de substituir a ineficiência do Estado, como muitas vezes ocorre em outros ramos do direito, mas de estabelecer novos parâmetros processuais diante da recorrência da violência no seio da sociedade.

A testemunha ou vítima não é mais ameaçada ou atingida por lentidão do procedimento ou outras mazelas, mas porque o crime progride em escala semelhante à das relações sociais e o processo clama por aprimoramento.

O mecanismo de proteção de testemunhas e vítimas é, pois, instituto necessário e, como tal, amparado pelos princípios processuais da ordem jurídica brasileira. Deve, portanto, ser aprimorado e redesenhado de modo a possibilitar a real eficiência do processo com proteção efetiva de testemunhas e vítimas.

No que alude à proteção de testemunhas, já se concluiu ter havido "alta costura legal”, que significa produção legislativa apenas para os reclamos midiáticos, eis que não há preocupação com sua eficácia. Insista-se, a lei questionada tenta uma ingerência para a qual o Estado não dispõe de suficiente poder.

Além disso, a carência de recursos para a implementação dos programas do Estado prejudica a exequibilidade e eficácia dos institutos previstos no Ordenamento Jurídico.

Arremata Luiz Flávio Gomes que o ponto nevrálgico da Lei no 9.807/99 é a carência de recursos para dotá-la de exequibilidade ${ }^{238}$.

Pannunzio, por sua vez, lembra que se trata de um dos mecanismos fundamentais para o combate à criminalidade e para a redução dos índices de violência no País, nada obstante sua necessidade de aprimoramento e respostas efetivas. É um desafio que

\footnotetext{
${ }^{238}$ Nos programas da Itália e dos Estados Unidos, v.g., gastam-se, como já se salientou, cerca de US\$ 50 a 100 milhões por ano, o que, evidentemente, está fora da realidade brasileira. Pode, nesse contexto, ser oportuna a ideia defendida por Belisário dos Santos Júnior de se utilizar como recursos adicionais ao orçamento destinado ao programa de proteção o dinheiro proveniente dos bens apreendidos de condenados envolvidos no crime organizado. Desde que se trate, conforme já ponderou Alberto Zacharias Toron, de fructus sceleris e não de outros bens não relacionados com o delito praticado. De qualquer maneira, caso o Poder Público não viabilize concreta e eficazmente os vários programas de proteção enunciados, chegar-se-á à conclusão de que só the interessava mesmo o "simbolismo" de que é dotada toda lei que direta ou indiretamente se relacione com o Direito penal. Será, ao lado de quase duas dezenas de leis penais que foram editadas nesta década, mais uma ilusão, um engodo. (GomES, Luiz Flávio. Lei de proteção a vítimas e testemunhas: primeiras considerações. Repertório IOB de Jurisprudência: Civil, Processual, Penal e Comercial, n. 18/99 p. 436).
} 
condiciona a completa efetivação dos princípios e fundamentos da República, bem assim o integral respeito à dignidade da pessoa humana. ${ }^{239}$

Por fim, analisando o sistema de proteção, algumas conclusões são inevitáveis, assim entendidas aquelas que mais reclamam solução e sobre as quais este pesquisador fará as ponderações a seguir.

A primeira delas alude à exclusão do preso cautelar ou preso condenado do sistema de proteção da lei. Ainda que se tenha previsto a possibilidade de proteção ao réu colaborador, a regulamentação está distante de ser ideal.

Entende-se irrefutável a regra sobre a exclusão do protegido incompatível com o programa, mas o sistema não pode deixar de proteger a pessoa do réu colaborador ou, então, a pessoa que eventualmente esteja respondendo a processo criminal com ou sem prisão decretada.

Como se verificou durante toda a pesquisa, esses casos são de extrema relevância para a solução investigada e muitas vezes é a prova única da ocorrência do crime. Atribuir somente aos órgãos de segurança a proteção do réu colaborador ou testemunha presa cautelarmente é, assim, indesejável aos escopos legais ${ }^{240}$.

Outro ponto relevante da pesquisa está na utilização de orçamento público sem a correspondente prestação de contas mediante documentação própria, uma vez que haverá inevitável vazamento de informações, o que colide com o princípio do sigilo de dados do protegido que reveste o programa. Entretanto, o órgão executor não pode deixar de prestar

\footnotetext{
${ }^{239}$ PANNUNZIO, Eduardo. Os requisitos de ingresso nos programas de proteção a vítimas e testemunhas: uma análise à luz da legislação e das experiências internacionais. In: LIMA JR., Jaime Benvenuto (Org.). Direitos Humanos Internacionais. Recife: MNDH 2001. p. 25.

${ }^{240}$ Comentando o $\S 2^{\circ}$, do artigo $2^{\circ}$, da Lei n⿳⺈ 9.807/99, Paulo Martini concorda que: "Ficar sob a proteção do Estado demanda determinada restrição de comportamento e inexorável limitação do direito de ir, vir e permanecer, além da drástica e incômoda quebra da rotina do protegido. Se este não porta de acordo com a forma regrada do programa, que tem como intento fundamental preservar sua vida, não poderá ser por ele abrangido, uma vez que gerará despesas para o Estado sem que ocorra, em contrapartida, a efetiva proteção do envolvido. De igual modo, neste capítulo, a Lei à margem de sua aplicação os condenados que cumprem pena e os indiciados ou acusados que se encontram detidos cautelarmente... O legislador, nesta parte, foi infeliz ao prever a ressalva, haja vista ser de relevância para o inquérito policial ou processo criminal os elementos que a pessoa possa trazer á baila, no sentido de ancorar provas concludentes e não o seu estado de condenado ou preso provisório. ... Colocá-los em dependência separada dos demais presos ou adotar outras medidas especiais de segurança não é o mesmo que incluí-los em um dos programas especiais de proteção" (MARTINI, Paulo. Proteção especial a vítimas, testemunhas e aos réus colaboradores: considerações sobre a lei no 9.807 , de 13 de julho de 1999, p. 7).
} 
contas dos valores utilizados, sendo, portanto, necessário instituir uma forma adequada para o cumprimento dessa exigência.

No Provita São Paulo existe um Conselho Fiscal que é encarregado da verificação das contas do órgão de execução em face dos valores utilizados. Esse Conselho tem ampla responsabilidade e competência para a verificação de toda a documentação. Nesse caso, tem-se ao menos um órgão interno, formado por membros do Conselho Deliberativo, que se encarrega de verificar as contas.

Essa providência ainda não exime o programa da fiscalização por outros órgãos e isso deve ser regulamentado, sob pena do prejuízo mais em relação ao sigilo tão necessário para a garantia da proteção.

Não é possível ignorar nestas últimas observações a fragilidade do sistema no tocante à alteração do nome. Conforme salientado, existe a possibilidade de ineficácia da medida quando da alteração nos vários cadastros de nomes existentes no sistema jurídico, bem como nas situações de dívidas em relação aos credores, que evidentemente não podem ser prejudicados em benefício do protegido.

Aludida alteração deve ser automática e de forma a possibilitar a alteração em todos os cadastros existentes sem a necessidade de manutenção do registro anterior. O sistema deve possibilitar, v.g., a alteração da cédula de identidade e inclusão de nomes fictícios de filiação, alteração nos cadastros próprios dos trabalhadores, como sistema de previdência, no Ministério do Trabalho e na entidade bancária responsável pelo depósito de Fundo de Garantia do Tempo de Serviço (FGTS).

Esses são detalhes que não podem preocupar a testemunha, pois ela já está contribuindo com risco à própria vida. $\mathrm{O}$ trabalho de alteração deve ser do Estado e de forma eficaz, sem possibilitar "flanco aberto" para o vazamento de informação sobre a alteração de nomes.

Reitera-se que não é possível, assim, ignorar a importância da prova testemunhal, mas, ao contrário, esta deve ser preservada e cultivada a fim de possibilitar à testemunha a liberdade de manifestação e de esclarecimento.

A vontade de alcançar a solenidade da verdade - e este deve ser o objetivo do operador do direito - leva este trabalho de pesquisa a encarar o instituto da prova 
testemunhal e, por consequência, da proteção de vítimas e testemunhas como um dos caminhos necessários para o cumprimento da lei penal ou, bem assim, como mecanismo de efetividade do processo penal. 


\section{REFERÊNCIAS}

ALEXY, Robert. Teoria dos direitos fundamentais. Tradução de Virgílio Afonso da Silva. 5. ed. São Paulo: Malheiros, 2008.

ALMEIDA, José Raul Gavião de. Acesso efetivo à justiça. In: COSTA, José de Faria; SILVA, Marco Antonio Marques da (Org.). Direito penal especial, processo penal e direitos fundamentais. Visão luso-brasileira. São Paulo: Quartier Latin, 2006. p. 567-577.

AMARAL, Augusto Jobim do. Algumas (re)descrições sobre a verdade no processo penal. Boletim do Instituto Brasileiro de Ciências Criminais, São Paulo, Ibccrim, set. 2009.

AMORIM, Carlos. CV-PCC: a irmandade do crime. 7. ed. Rio de Janeiro: Record, 2006.

ARANHA, Adalberto José Queiroz Telles de Camargo. Da prova no processo penal. 7. ed. São Paulo: Saraiva, 2006.

ATALIBA, Geraldo. República e Constituição. 2. ed. atualizada por Rosalea Miranda Folgosi. São Paulo: Malheiros, 1998.

BADARÓ, Gustavo H. R. Ivahy. Ônus da prova no processo penal. São Paulo: RT, 2003.

BECHARA, Fábio Ramazzini. Criminalidade organizada e procedimento diferenciado: entre eficiência e garantismo. In: COSTA, José de Faria; SILVA, Marco Antonio Marques da (Org.). Direito penal especial, processo penal e direitos fundamentais. Visão luso-brasileira. São Paulo: Quartier Latin, 2006. p. 909-937.

BECHARA, Fábio Ramazzini; MANZANO, Luís Fernando de Moraes. Crime organizado e terrorismo nos Estados Unidos da América. In: FERNANDES, Antonio Scarance; ALMEIDA, José Raul Gavião de; MORAES, Maurício Zanoide (Org.). Crime organizado - aspectos processuais. São Paulo: RT, 2009. p. 153-184.

BECK, Francis Rafael. Perspectivas de controle ao crime organizado e crítica à flexibilização das garantias. São Paulo: Ibccrim, 2004. (Concurso de monografias jurídicas).

BEDAQUE, José Roberto dos Santos. Poderes instrutórios do juiz. 2. ed. São Paulo: RT, 1994.

BEDAQUE, José Roberto dos Santos. Efetividade do processo e técnica processual. 2. ed. São Paulo: Malheiros, 2007.

BERTOLINO, Pedro J. Acerca de la viabilidad de los denominados "Testigos de Identidad Reservada" en el ordenamiento procesal penal de la provincia de Buenos Aires. In: Suplemento de Jurisprudencia Penal y Procesal Penal, 30 jul. 2004. p. 8-17. 
BONAVINA, Mônica Aparecida. As medidas especiais de proteção a vítimas, testemunhas e réus colaboradores e o reconhecimento da taxa judiciária junto à justiça federal. Boletim dos Procuradores da República, ano 2, n. 21, p. 21-23, jan. 2000.

BRUNO NETO, Mario Augusto. O Direito em debate: breves considerações acerca do Provimento n. 32/00. Boletim IBCCRIM, São Paulo, v. 13, n. 152, p. 14-15, jul. 2005.

CAÇAPAVA, Elisa Pires da Cruz Reale; VILARES, Fernanda Regina. Crime organizado e terrorismo na França. In: FERNANDES, Antonio Scarance; ALMEIDA, José Raul Gavião de; MORAES, Maurício Zanoide (Org.). Crime organizado - aspectos processuais. São Paulo: RT, 2009. p. 185-206.

CALHAU, Lélio Braga. Vítima, justiça criminal e cidadania. Revista Brasileira de Ciências Criminais, São Paulo: RT, ano 8, p. 228-241, jul.-set. 2000.

CAPEZ, Fernando. Curso de processo penal. 15. ed. São Paulo: Saraiva, 2008.

CARNEIRO, Athos Gusmão. Jurisdição e competência. 8. ed. São Paulo: Saraiva, 1997.

CASTRO, Raimundo Amorim de. Provas ilícitas e o sigilo das comunicações telefônicas. Curitiba: Juruá, 2007.

CATENA, Victor Moreno. La protección de los testigos y peritos en el proceso penal español. Revista Penal, Salamanca, n. 4, p. 58-67, 1998.

CINTRA, Antonio Carlos de Araújo; GRINOVER, Ada Pellegrini; DINAMARCO, Cândido Rangel. Teoria geral do processo. 9. ed. São Paulo: Malheiros, 1992.

COGAN, Marco Antonio Pinheiro Machado; JOSÉ, Maria Jamile. O crime organizado e terrorismo na Espanha. In: FERNANDES, Antonio Scarance; ALMEIDA, José Raul Gavião de; MORAES, Maurício Zanoide (Org.). Crime organizado - aspectos processuais. São Paulo: RT, 2009. p. 123152.

DAMASKA, Mirjan R. Las caras de la Justicia y el poder del Estado. Santiago de Chile: Jurídica de Chile, 1986.

DELMAS-MARTY, Mireille (Org.). Processos Penais da Europa. Tradução de Fauzi Hassan Choukr e Ana Cláudia Ferigato Choukr. Rio de Janeiro: Lumen Juris, 2005.

DERVIEUX, Valérie. O sistema francês. In: DELMAS-MARTY, Mireille (Org.). Processos penais da Europa. Tradução de Fauzi Hassan Choukr e Ana Cláudia Ferigato Choukr. Rio de Janeiro: Lumen Juris, 2005. p. 167.

D’URSO, Luiz Flávio Borges. Programa de Proteção aos Colaboradores da Justiça Criminal no Brasil - vítimas e testemunhas. Informativo Consulex, v. 5, p. 1.136-1.137, nov. 1996. 
D’URSO, Luiz Flávio Borges. Programa de Proteção à Vítima e às Testemunhas no Brasil. Revista do Instituto de Pesquisas e Estudos da Instituição Toledo de Ensino de Bauru, v. 16, p. 319-326, nov. 1996-mar. 1997.

DECOMAIN, Pedro Roberto. Proteção a testemunhas: redução de pena para o acusado que colabora com a investigação criminal. Revista do Ministério Público/Ministério Público do Estado do Rio de Janeiro, n. 12, p. 137-180, jul./dez. 2000.

DEPINÉ FILHO, Davi Eduardo. O direito em debate: para que serve o Provimento n. 32/00. Boletim IBCCRIM, São Paulo, v. 13, n. 152, p. 16-17, jul. 2005.

DINAMARCO, Cândido Rangel. Fundamentos do processo civil moderno. 5. ed. São Paulo: Malheiros, 2002. Tomo I.

DINAMARCO, Cândido Rangel. Instituições de direito processual civil. 3. ed. São Paulo: Malheiros, 2003. v. I.

DINAMARCO, Cândido Rangel. A instrumentalidade do processo. 13. ed. São Paulo: Malheiros, 2008.

ESPÍNOLA FILHO, Eduardo. Código de processo penal brasileiro anotado. 5. ed. Rio de Janeiro: Rio, 1976.

FERNANDES, Antonio Scarance. Teoria geral do procedimento e o procedimento no processo penal. São Paulo: RT, 2005.

FERNANDES, Antonio Scarance. Processo penal constitucional. 4. ed. São Paulo: RT, 2005.

FERNANDES, Antonio Scarance; MARQUES, Oswaldo Henrique Duek. O Estado na reparação do dano à vítima de crime. Justitia, ano 53, v. 156. São Paulo: Procuradoria-Geral de Justiça, p. 2534, out.-dez. 1991.

FERNANDES, Antonio Scarance. O equilíbrio entre a eficiência e o garantismo e o crime organizado. Revista Brasileira de Ciências Criminais, São Paulo: RT, ano 16, n. 70, p. 229-268, jan.-fev. 2008.

FERNANDES, Antonio Scarance. Prova e sucedâneos da prova no processo penal. Revista Brasileira de Ciências Criminais, São Paulo: RT, v. 66, p. 193-236, maio-jun. 2007.

FERNANDES, Maria Cristina. Testemunhas atrás de proteção. Revista Época, ano 1, n. 14, p. 3033, ago. 1998.

FERRAJOLI, Luigi. Direito e razão - teoria do garantismo penal. 2. ed. São Paulo: RT, 2006.

FONTANA, Milton. Vítima e justiça penal: o processo da vitimação do ofendido. Estudos Jurídicos da Universidade do Vale do Rio dos Sinos, v. 27, n. 70, p. 21-35, maio/ago. 1994. 
FRIEDE, Roy Reis. Eficiência: um imperativo para o poder judiciário. Revista de Processo, São Paulo: RT, n. 68, p. 59-68, 1992.

GOMES FILHO, Antonio Magalhães. Direito à prova no processo penal. São Paulo: RT, 1997.

GOMES FILHO, Antonio Magalhães; BADARÓ, Gustavo H. R. Ivahy. Prova e sucedâneos de prova no processo penal brasileiro (Relatório brasileiro para as XX Jornadas Ibero-Americanas de Direito Processual). Málaga, Espanha, 2006.

GOMES, Luiz Flávio. Crime organizado: que se entende por isso depois da Lei n⿳⺈ 12.217/01?, Jus Navigandi, 22 maio 2007.

GOMES, Luiz Flávio. Lei de proteção a vítimas e testemunhas: primeiras considerações. Repertório IOB de Jurisprudência: Civil, Processual, Penal e Comercial, n. 18, set. 1999, Caderno 3, p. 434-436.

GOMES, Luiz Flávio; CERVINI, Raúl. Crime organizado: enfoques criminológico, jurídico (Lei 9.034/95) e político-criminal. 2. ed. São Paulo: RT, 1997.

GRINOVER, Ada Pellegrini. A iniciativa instrutória do juiz no processo penal acusatório. Revista Brasileira de Ciências Criminais, São Paulo: RT, n. 27, p. 71-79, 1999.

GRINOVER, Ada Pellegrini. O processo em evolução. Rio de Janeiro: Forense Universitária, 1996.

GRINOVER, Ada Pellegrini. O crime organizado no sistema italiano. Revista dos Tribunais Instituto Brasileiro de Ciências Criminais, São Paulo: RT, n. 12, p. 76-86, out.-dez. 1995.

GRINOVER, Ada Pellegrini; FERNANDES, Antonio Scarance; GOMES FILHO, Antonio Magalhães. As nulidades no processo penal. 2. ed. São Paulo: Malheiros, 1992.

GÜNTHER, Ulrich. Proteção de vítimas e testemunhas no processo penal na Alemanha. Revista de Direito Mackenzie, São Paulo, ano 1, n. 2, p. 135-137, 2000.

HASSEMER, Wilfried. Segurança pública no Estado de Direito. Tradução de Carlos Eduardo Vasconcelos. Revista Brasileira de Ciências Criminais, São Paulo: RT, ano 2, n. 5, p. 55-69, 1994.

GRINOVER, Ada Pellegrini. A iniciativa instrutória do juiz no processo penal. Revista Brasileira de Ciências Criminais, São Paulo: RT, n. 27, p. 71-79, 1999.

JUY-BIRMANN, Rudolphe. O sistema alemão. In: DELMAS-MARTY, Mireille (Org.). Processos penais da Europa. Tradução de Fauzi Hassan Choukr e Ana Cláudia Ferigato Choukr. Rio de Janeiro: Lumen Juris, 2005. p. 22. 
KAWAMOTO, Silvia Reiko. Breves apontamentos sobre o crime organizado e a proteção à testemunha na Itália e nos Estados Unidos. Revista Justiça Penal, São Paulo: RT, n. 7, p. 410-433, 2000.

KELLEY, Augustos M. A History of Continental Criminal Procedure. New York [s.ed.], 1968, p. 92/93.

LARONGA, Antonio. Le prove atipiche nel processo penale. Padova: Cedam, 2002.

LIPINSKI, Antonio Carlos. Crime organizado e a prova penal. 4. tiragem. Curitiba: Juruá, 2006. v. I.

LOPES JR., Aury. Introdução crítica ao processo penal (fundamentos da instrumentalidade garantista). 3. ed. Rio de Janeiro: Lúmen Juris, 2005.

LOURENÇO, Messias José. Crime organizado e lei de proteção de testemunhas. Lex Jurisprudência do Superior Tribunal de Justiça e Tribunais Regionais Federais, v. 16, n. 181, p. 922, set. 2004.

MACHADO, André Augusto Mendes; SouZA, Diego Fajardo Maranha Leão de. O crime organizado na Colômbia. In: FERNANDES, Antonio Scarance; ALMEIDA, José Raul Gavião de; MORAES, Maurício Zanoide (Org.). Crime organizado - aspectos processuais. São Paulo: RT, 2009. p. 86-122.

MAIEROVITCH, Walter Fanganiello. As associações criminosas transnacionais. In: Justiça penal 3 - críticas e sugestões. São Paulo: RT, 1995. p. 58-76.

MALATESTA, Nicola Framarino dei. A lógica das provas em matéria criminal. São Paulo: Saraiva, 1960. v. I.

MARQUES, José Frederico. Elementos de direito processual penal. São Paulo: Millenium, 2003.

MARQUES, José Frederico. Instituições de direito processual civil. Atualizada por Ovídio Rocha Barros Sandoval. Campinas: Millennium, 2000. v. I.

MARTINI, Paulo. Proteção especial a vítimas, testemunhas e réus colaboradores: considerações sobre a Lei n. 9.807, de 13 de julho de 1999. Porto Alegre: Síntese, 2000.

MARTINS, Teresa Alves; ROCHA, Rosa Maria. Prova e sucedâneos de prova em processo penal Relatório Nacional de Portugal. In: Prova e sucedâneos da prova no processo penal. Revista Brasileira de Ciências Criminais, São Paulo: RT, v. 66, p. 193-236, maio-jun. 2007.

MELLO, Marco Aurélio. Judiciário: do caos à ordem. Revista da Academia Paulista de Magistrados, São Paulo, ano II, n. 2, 2002. 
MELO, Wilhiam Antônio de. Suspensão do contrato de trabalho de empregado protegido por Programa de Proteção a Testemunha. Revista Jurídica do Ministério da Defesa, v. 1, n. 2, p. 61-64, mar. 2005.

MENDONÇA, Andrey Borges de. Nova reforma do Código de processo penal. São Paulo: Método, 2008.

MENDRONI, Marcelo Batlouni. Crime organizado - aspectos gerais e mecanismos legais. 2. ed. São Paulo: Atlas, 2007.

MIGUEL, Alexandre; PEQUENO, Sandra Maria Nascimento de Souza. Comentários à lei de proteção às vítimas, testemunhas e réus colaboradores. Revista dos Tribunais, v. 89, São Paulo, n. 773, p. 425-443, mar. 2000.

MISCHKEWITZ, Andréas. Proteção de testemunhas no Kosovo. In: $4^{\underline{0}}$ SIMPÓSIO INTERNACIONAL DOS PROGRAMAS DE PROTEÇÃO A VÍTIMAS E TESTEMUNHAS, setembro de 2009, Praia do Forte, Salvador, 2009.

MOREIRA, José Carlos Barbosa. A função social do processo civil moderno e o papel do juiz e das partes na direção e na instrução do processo. In: Temas de direito processual. São Paulo: Saraiva, 1984. p. 43-56.

MOREIRA, José Carlos Barbosa. Notas sobre o problema da efetividade do processo. In: Temas de direito processual: terceira série. São Paulo: Saraiva, 1984.

MOURA, Maria Thereza Rocha de Assis. Delação premiada. Revista Del Rey Jurídica, Belo Horizonte, ano 8, n. 16, p. 67-70, $1^{\circ}$ sem. 2006.

MOURÃO, Alberto. Lei de proteção a vítimas e as testemunhas. Brasília: Câmara dos Deputados, Coordenação de Publicações, 2002.

NORONHA, E. Magalhães. Curso de direito processual penal. Atualizado por Adalberto José Q. T. de Camargo Aranha. 27. ed. São Paulo: Saraiva, 1999.

NUCCI, Guilherme de Souza. O valor da confissão como meio de prova no processo penal. 2. ed. São Paulo: RT, 1999.

OLIVEIRA JÚNIOR, Eudes Quintino. Algumas considerações a respeito da lei de proteção a vítimas e testemunhas (Lei 9.807, de 13.07.1999). Revista Jurídica da Universidade de Franca, São Paulo, v. 2, n. 3, p. 49-56, nov. 1999.

OLIVEIRA, Carlos Álvaro de. Do formalismo no processo civil. 2. ed. São Paulo: Saraiva, 2003.

OLIVEIRA, Neide M. Cardoso de. Programa de proteção a testemunhas. Boletim dos Procuradores da República, v. 2, n. 13, p. 28-30, maio 1999. 
PACHECO, Denílson Feitoza. O princípio da proporcionalidade no direito processual penal brasileiro. Rio de Janeiro: Lúmen Juris, 2007.

PANNUNZIO, Eduardo. Os requisitos de ingresso nos programas de proteção a vítimas e testemunhas: uma análise à luz da legislação e das experiências internacionais. In: LIMA JR., Jaime Benvenuto (Org.). Direitos humanos internacionais. Recife: MNDH, 2001.

PEREIRA, Fábio Franco; HÖHN JR., Ivo Anselmo. O combate ao crime organizado e ao terrorismo na Inglaterra. In: FERNANDES, Antonio Scarance; ALMEIDA, José Raul Gavião de; MORAES, Maurício Zanoide (Org.). Crime organizado - aspectos processuais. São Paulo: RT, 2009. p. 207-231.

PÉREZ, Rafael Fernández. Elementos para una efectiva protección de los derechos de las victimas en el proceso penal. Boletín Mexicano de Derecho Comparado, México: Instituto de Investigaciones Jurídicas - Universidad Nacional Autónoma de México, año XXVIII, n. 82, p. 111133, enero-abr. 1995.

PESQUIÉ, Brigitte. O sistema belga. In: DELMAS-MARTY, Mireille (Org.). Processos penais da Europa. Tradução de Fauzi Hassan Choukr e Ana Cláudia Ferigato Choukr. Rio de Janeiro: Lumen Juris, 2005.

PINHEIRO FILHO, Anatólio; GUIMARÃES, Fabiano Pinheiro. A possibilidade de novas nulidades processuais penais, frente à lei $\mathrm{n}^{\mathrm{o}} 9.807 / 99$ (programa de proteção a vítimas e testemunhas). Informativo Jurídico Consulex, São Paulo, v. 16, n. 29, p. 5-6. jul. 2001.

PLETSCH, Natalie Ribeiro. Formação da prova no jogo processual penal. O atuar dos sujeitos e a construção da sentença. São Paulo: Ibccrim, 2007.

RAMOS, João Gualberto Garcez. Curso de processo penal norte-americano. São Paulo: RT, 2006.

RINALDI, Stanislao. Criminalidade organizada de tipo mafioso e poder político na Itália. Revista Brasileira de Ciências Criminais, ano 6, n. 22, p. 11-25, abr./jun. 1998.

RODRIGUES, Francisco César Pinheiro. Criminalidade e proteção às testemunhas: Breves considerações sobre a pena de morte. Revista do Instituto dos Advogados de São Paulo, v. 5, n. 10, jul./dez. 2002.

ROESLER, Átila da Rold. A falácia do combate ao crime organizado. Jus Navigandi, In: http://jus2.uol.com.br/doutrina/texto.asp?id=5214. Acesso em: 22 maio 2007.

ROSA, Inocêncio Borges da. Comentários ao Código de processo penal. 3. ed. São Paulo: RT, 1982. p. 315. In: DECOMAIN, Pedro Roberto. Proteção a testemunhas: redução de pena para o acusado que colabora com a investigação criminal. Revista do Ministério Público/Ministério Público do Estado do Rio de Janeiro, n. 12, p. 140, jul./dez. 2000. 
ROSAS, Roberto. Efetividade e instrumentalidade. Estruturação processual: caminhos de uma reforma. Revista de Processo, São Paulo: RT, v. 85, p. 212-221, 1997.

RUSSO, Luciana; GEMAQUE, Silvio César Arouck. Crime organizado em Portugal. In: FERNANDES, Antonio Scarance; ALMEIDA, José Raul Gavião de; MORAES, Maurício Zanoide (Org.). Crime organizado - aspectos processuais. São Paulo: RT, 2009. p. 280-303.

SILVA, Dalmo. A proteção dos direitos da vítima. Revista de Direito do Tribunal de Justiça do Estado do Rio de Janeiro, n. 12, p. 22-25, jul.-set. 1992.

SILVA, Eduardo Araujo. Crime organizado. São Paulo: Atlas, 2003.

SILVA NETO, Manoel Jorge e. Aspectos trabalhistas da lei de proteção às vítimas e testemunhas de crime. Gênesis: Revista do Trabalho, v. 19, n. 113, p. 732-735, maio 2002.

SOUZA, Marcus Valério Guimarães de. A lei de proteção a testemunhas. Informativo Jurídico Consulex, São Paulo, v. 15, n. 30, p. 5-6, 23 jul 2001.

TARUFFO, Michele. La prueba de los hechos. 2. ed. Madrid: Trotta, 2005.

TONINI, Paolo. A prova no processo penal italiano. Tradução de Alexandra Martins e Daniela Mróz. São Paulo: RT, 2002.

TORNAGHI, Hélio. Curso de processo penal. 3. ed. São Paulo: Saraiva, 1983.

TOURINHO FILHO, Fernando da Costa. Código de processo penal comentado. 10. ed. São Paulo: Saraiva, 2007. v. 1-3.

TOURINHO FILHO, Fernando da Costa. Processo penal. São Paulo: Saraiva, 1990.

TUCCI, José Rogério Cruz e; TUCCI, Rogério Lauria. Constituição de 1988 e processo, regramentos e garantias. São Paulo: Saraiva, 1989.

TUCCI, José Rogério Cruz e; TUCCI, Rogério Lauria. Processo civil, realidade e justiça: 20 anos de vigência do CPC. São Paulo: Saraiva, 1994.

VAGGIONE, Luiz Fernando; SILVEIRA, Rodrigo Mansour Magalhães da. O crime organizado na Itália e as medidas adotadas para o seu combate. In: FERNANDES, Antonio Scarance; ALMEIDA, José Raul Gavião de; MORAES, Maurício Zanoide (Org.). Crime organizado - aspectos processuais. São Paulo: RT, 2009. p. 232-250.

VAROTO, Renato Luiz Mello. Da proteção de testemunhas. Repertório IOB de Jurisprudência: Civil, Processual, Penal e Comercial, v. 20, p. 471-473, out. 1999.

VELLOSO, Carlos Mário. Problemas e soluções na prestação da justiça. In: Temas de direito público. Belo Horizonte: Del Rey, 2003. 
WAMBIER, Luiz Rodrigues; WAMBIER, Teresa Arruda Alvim. Anotações sobre a efetividade do processo. Revista dos Tribunais, São Paulo, n. 814, p. 63-70, 2003.

YARSHELL, Flávio Luiz. Tutela jurisdicional. São Paulo: Atlas, 1998.

ZAMORA AVILA, Martha Lucía. Tratamiento jurídico-penal de puesta en peligro de la víctima con su consentimiento. Revista Del Instituto de Ciencias Penales y Criminológicas de la Universidad Externato de Colómbia, Bogotá, v. 13, n. 44, p. 37-55, mayo/agosto 1991.

ZILLI, Marcos Alexandre Coelho. A iniciativa instrutória do juiz no processo penal. São Paulo: RT, 2003.

\author{
Sites \\ www.clarin.com \\ www.gajop.org.br \\ www.infoleg.gov.ar \\ www.latinlaws.com \\ www.legifrance.gouv.fr \\ www.legislacao.vlex.pt \\ www.mpf.gov.ar \\ www.normeinrete.it \\ www.noticias.juridicas.com \\ www.opsi.gov.uk \\ www.pagina12.com.ar \\ www.presidencia.gov.co \\ www.srbija.gov.rs \\ www.stf.gov.br \\ www.tj.sp.gov.br \\ www.todoelderecho.com \\ www1.hcdn.gov.ar
}

